QA: N/A

TDR-CRW-SE-000023 REV 00

August 2002

\title{
Modular Construction System Evaluation
}

\section{Pre-Decisional Study}

Prepared for:

U.S. Department of Energy

Office of Civilian Radioactive Waste Management 1000 Independence Avenue, S.W.

Washington, DC 20585

\section{Prepared by:}

Bechtel SAIC Company, LLC

1180 Town Center Drive

Las Vegas, Nevada 89144

Under Contract Number

DE-AC28-01RW12101 


\section{DISCLAIMER}

This report was prepared as an account of work sponsored by an agency of the United States Government. Neither the United States Government nor any agency thereof, nor any of their employees, nor any of their contractors, subcontractors or their employees, makes any warranty, express or implied, or assumes any legal liability or responsibility for the accuracy, completeness, or any third party's use or the results of such use of any information, apparatus, product, or process disclosed, or represents that its use would not infringe privately owned rights. Reference herein to any specific commercial product, process, or service by trade name, trademark, manufacturer, or otherwise, does not necessarily constitute or imply its endorsement, recommendation, or favoring by the United States Government or any agency thereof or its contractors or subcontractors. The views and opinions of authors expressed herein do not necessarily state or reflect those of the United States Government or any agency thereof. 
TDR-CRW-SE-000023 REV 00

August 2002

Modular Construction System Evaluation

Prepared by:

Loom \& Sillogi

Scott Gillespie

Checked by:

Marshall Weave

Marshall Weaver
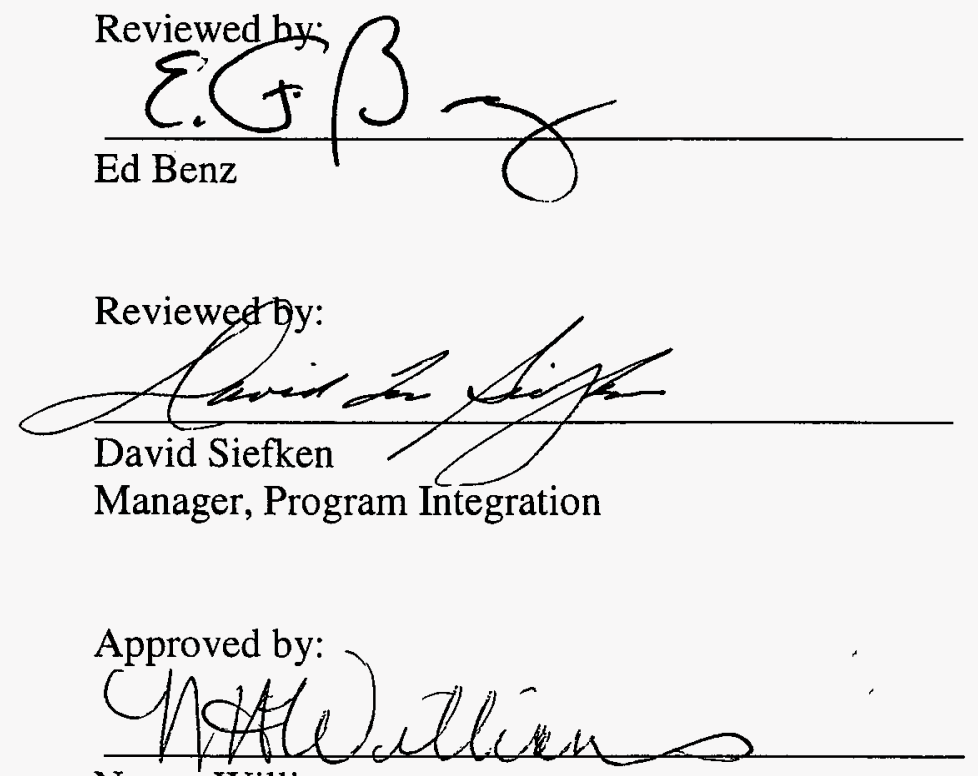

Nancy Williams

Manager of Projects
$8 / 8 / 02$

Date

$\frac{8 / 9 / 02}{\text { Date }}$

$\frac{8 / 8 / 2}{\text { Date }}$

$\frac{8 / 8 / 02}{\text { Date }}$

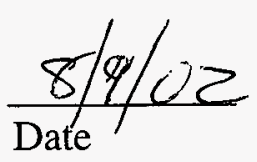




\section{CHANGE HISTORY}

$\begin{array}{lll}\begin{array}{l}\text { Revision } \\ \text { Number }\end{array} & \begin{array}{l}\text { Interim } \\ \text { Change No. }\end{array} & \begin{array}{l}\text { Effective } \\ \text { Date }\end{array} \\ & \frac{\text { N/A }}{0} & \end{array}$

Description of Change

Initial Issue 
INTENTIONALLY LEFT BLANK 


\section{EXECUTIVE SUMMARY}

\section{PURPOSE AND SCOPE}

The purpose of this study is to respond to U.S. Department of Energy (DOE) Technical Direction Letter (TDL) 02-003 (Waisley 2001), which directs Bechtel SAIC Company, LLC (BSC) to complete a design study to recommend repository design options to support receipt and/or emplacement of any or all of the following: commercial spent nuclear fuel (CSNF), high-level radioactive waste (HLW), DOE-managed spent nuclear fuel (DSNF) (including naval spent nuclear fuel $[\mathrm{SNF}]$ ), and immobilized plutonium (if available), as soon as practicable, but no later than 2010. From the possible design options, a recommended approach will be determined for further evaluation to support the preliminary design of the repository.

This study integrates the results of the repository Design Evolution Study (Rowe 2002) with supporting studies concerning national transportation options (BSC 2002b) and Nevada transportation options (Gehner 2002). The repository Design Evolution Study documents the processes used to reevaluate the design, construction, operation, and cost of the repository in response to TDL 02-003 (Waisley 2001), and to determine possible repository conceptual design options. The transportation studies evaluate the national and Nevada transportation options that support the repository conceptual design options. An evaluation methodology was established, based on Program-level requirements developed for the study in reference BSC 2001a, to allow the repository and system design options to be evaluated on a consistent basis. The transportation options and the design components were integrated into system design implementation options, which were evaluated using receipt and emplacement scenarios. The scenarios tested the ability of the design concept to adapt to changes in funding, waste receipt rate, and Nevada rail transportation availability. The results of the evaluation (in terms of system throughput, cost, and schedule) were then compared to the Program-level requirements, and recommendations for design alternatives, requirements changes, or further evaluation were developed.

\section{ANALYSIS}

Seven receipt and emplacement scenarios were developed to evaluate the recommended design concept.

\section{- Scenario 1 - Mostly Rail, Reference Receipt Rates}

This scenario assumes that wastes are transported to the repository in accordance with the target schedule in the Civilian Radioactive Waste Management System Requirements Document (CRD) (DOE 2001a, Table 1). CSNF selection for transport at utility sites is in accordance with the "youngest fuel first greater than 10 years old" (YFF10) criterion (see Appendix A for definition). Transportation is "mostly rail" (i.e., rail with legal weight truck [LWT] transport only for sites that cannot handle a rail cask). Waste is emplaced as received, with no storage. Emplacement occurs first in the subsurface Panel 1, followed immediately by emplacement in Panel 2 and subsequent panels as needed. Surface facility phases are constructed as needed to meet the receipt rate. 


\section{- Scenario 2 - Mostly Rail, Initial APR/ACR Receipt Rate}

This scenario assumes the same transportation modes as Scenario 1. The CSNF receipt rate is capped at the maximum rate shown in the Acceptance Priority Ranking/Acceptance Capacity Report (APR/ACR) (DOE 1995a) for 10 years (until 2019). Beginning in 2020, the CSNF receipt rate ramps up to 3,600 metric tons of heavy metal (MTHM)/year to allow the receipt schedule to catch up to the CRD target schedule.

- Scenario 3 - Mostly Rail, Reference Receipt Rate, Delayed Emplacement

This scenario is similar to Scenario 1, except that after the testing area in Panel 1 is filled (approximately 1200 MTHM of CSNF and a proportional amount of defense wastes), no more waste is emplaced until 2020. This simulates a postulated requirement to perform testing on the waste emplaced in the testing area prior to proceeding with further emplacement. During this time (2013-2019), all of the waste received is assumed to be stored on the surface. In addition, construction of subsurface Panels 2-4 is delayed by 8 years. After 2019, waste emplacement resumes, at a CSNF rate 3,600 MTHM/year.

\section{- Scenario 4 - Mostly Rail, Accelerated Receipt and Emplacement Rate}

This scenario is similar to Scenario 1, but assumes that the CSNF waste receipt and emplacement rates are increased by $1 / 3$ to a maximum of $4,000 \mathrm{MTHM} / \mathrm{year}$.

\section{- Scenario 5 - Initial Truck/Heavy Haul, Low Rate}

This scenario assumes that the Nevada rail line will not be available until 2015; therefore, transportation to the repository during the first 5 years of operation will be by LWT and limited heavy haul (for naval SNF only). The initial CSNF transportation rate is limited to $100 \mathrm{MTHM} / \mathrm{year}$, and the HLW transportation rate is limited to $10 \mathrm{MTHM} / \mathrm{year}$. Naval SNF is assumed to be shipped by heavy haul until 2015 . The CSNF receipt rate ramps up to 3,600 MTHM/year after 2014, to allow the receipt to catch up with the CRD target schedule; the defense wastes receipt rates ramp up to the reference rate. Construction of subsurface Panels 2 - 4 is delayed by 3 years.

\section{- Scenario 6 - Initial Truck/Heavy Haul, High Rate}

This scenario is similar to Scenario 5, except that the initial (2010-2014) receipt rates for CSNF and defense wastes (except naval SNF) are increased by a factor of four.

\section{- Scenario 7 - Initial Truck/Heavy Haul, High Rate, 2 Year Rail Delay}

This scenario is similar to Scenario 6, but assumes that the Nevada rail line will become operational in 2012, instead of 2015.

For each of the receipt and emplacement scenarios, the construction and operation of the modular components of the repository surface facilities were time-phased to match the receipt, aging, and emplacement rates. This was accomplished by matching the capabilities of the modular components to the annual receipt rates. 
It should be noted that the preliminary construction schedules developed for the surface and subsurface facilities in the Design Evolution Study (Rowe 2002) result in an initial operation date of December 2010. While this meets the goal of 2010 initial operation, it does not allow for receipt and processing of a significant quantity of waste in calendar year 2010 (certainly not approaching the CRD target level of 400 MTHM CSNF). However, for the purpose of performing the cost analysis, this inconsistency was not considered (i.e., receipt and emplacement rates were assumed to match the values given in Appendix C).

Direct costs for facilities that have changed from the Site Recommendation (SR) design, per this study, were based on unit rates derived from the May 2001 Total System Life Cycle Cost (TSLCC) estimate. For the facilities that are unchanged from the SR design, the direct costs were based on the total direct cost values from the May 2001 TSLCC. The operations and maintenance (O\&M) costs were based on the May 2001 TSLCC estimate, adjusted for items included in other parts of the estimate. O\&M costs were also adjusted for each scenario to account for variations in receipt and emplacement rates.

Repository indirect costs include engineering, licensing, management support, administration, Payments Equivalent to Taxes (PETT), Benefits (i.e., payments to the state of Nevada and local governments), and Program Integration and Institutional (PI\&I) costs. These costs were calculated based on rates from the May 2001 TSLCC. In addition, the contingency factors used in the May 2001 TSLCC were reviewed and increased as necessary to reflect the conceptual nature of the modular design concept.

\section{RESULTS}

Table ES-1 summarizes the logistics results for the 7 scenarios, as compared to the May 2001 TSLCC reference case. Note that the Maximum CSNF Storage Capability in Table ES-1 is the amount of storage capability costed in the analysis, not the maximum actually in storage at any one time.

Table ES-1. Logistics Results

\begin{tabular}{|c|c|c|c|}
\hline Scenario & $\begin{array}{c}\text { Total CSNF Accepted, } \\
\text { 2010-20 } \\
\text { (MTHM) }\end{array}$ & $\begin{array}{c}\text { Total CSNF Emplaced, } \\
\text { 2010-20 } \\
\text { (MTHM) }\end{array}$ & $\begin{array}{c}\text { Maximum CSNF Storage } \\
\text { Capability } \\
\text { (MTHM) }\end{array}$ \\
\hline TSLCC & 25,200 & 25,200 & $5,000^{1}$ \\
\hline 1 & 25,200 & 25,200 & $1,400^{2}$ \\
\hline 2 & 10,000 & 10,000 & $1,400^{2}$ \\
\hline 3 & 25,200 & 4,800 & $21,400^{2}$ \\
\hline 4 & 33,610 & 33,610 & $1,400^{2}$ \\
\hline 5 & 11,250 & 11,250 & $1,400^{2}$ \\
\hline 6 & 12,600 & 12,600 & $1,400^{2}$ \\
\hline 7 & 19,800 & 19,800 & $1,400^{2}$ \\
\hline
\end{tabular}
Pool storage for blending purposes
Comprised of 400 MTHM pool storage, with the remainder in dry storage


Of the 7 scenarios, only scenarios 1, 3, and 4 meet or exceed the May 2001 TSLCC total receipt through 2020, and only scenarios 1 and 4 meet or exceed the May 2001 TSLCC total emplacement through 2020. Scenarios 5 - 7 fail to meet the TSLCC receipt and emplacement totals through 2020 due to the low initial receipt rate caused by delayed Nevada rail construction. Scenario 2 fails to meet the TSLCC total receipt and emplacement due to limiting the receipt rate for the first 10 years to the APR/ACR rate. Scenario 3 meets the TSLCC total receipt through 2020 , but fails to meet the TSLCC total emplacement, due to the moratorium on emplacement from 2013-2019.

Table ES-2 shows the total Civilian Radioactive Waste Management System (CRWMS) future costs through 2010 and 2020, as well as the peak annual costs through 2010 for the 7 scenarios and the May 2001 TSLCC.

Table ES-2. CRWMS Future Costs, 2002-2020 (M 2002\$) $)^{1}$

\begin{tabular}{|c|c|c|c|c|c|c|c|c|}
\hline FY & TSLCC & Scen 1 & Scen 2 & Scen 3 & Scen 4 & Scen 5 & Scen 6 & Scen 7 \\
\hline $\begin{array}{c}\text { Total } \\
2002-10\end{array}$ & 8,970 & 7,930 & 7,610 & 7,470 & 8,070 & 6,410 & 6,950 & 7,490 \\
\hline $\begin{array}{c}\text { Total } \\
2002-20\end{array}$ & 19,570 & 21,190 & 18,640 & 19,150 & 22,340 & 17,960 & 18,780 & 20,110 \\
\hline $\begin{array}{c}\text { Peak } \\
2002-10\end{array}$ & 1,630 & 1,540 & 1,520 & 1,290 & 1,720 & 1,060 & 1,370 & 1,480 \\
\hline
\end{tabular}

Costs rounded to the nearest $\$ 10$ million

Note that all of the scenarios exhibit lower total costs through 2010 than the May 2001 TSLCC, and all but Scenario 4 exhibit lower peak costs through 2010. Scenarios 1,4, and 7 exhibit higher total costs through 2020 than the May 2001 TSLCC.

Table ES-3 shows the total life cycle cost for receipt and emplacement of 97,800 MTHM for the May 2001 TSLCC and the 7 scenarios.

Table ES-3. Total Life Cycle Cost for 97,800 MTHM Emplacement (B 2002\$)

\begin{tabular}{|c|c|c|c|c|c|c|c|}
\hline Scenario & $\begin{array}{c}\text { Historical } \\
\text { Costs }\end{array}$ & WAST & $\begin{array}{c}\text { Nevada } \\
\text { Transportation }\end{array}$ & Repository & PI\&I & Total & $\begin{array}{c}\text { Delta to May } \\
\text { 2001 TSLCC }\end{array}$ \\
\hline $\begin{array}{c}\text { May 2001 } \\
\text { TSLCC }\end{array}$ & 9.0 & $6.2^{2}$ & 0.9 & 37.5 & $6.4^{3}$ & 60.0 & 0 \\
\hline 1 & 9.0 & 5.6 & 1.0 & 40.6 & 6.8 & 62.9 & 2.9 \\
\hline 2 & 9.0 & 5.7 & 1.0 & 40.2 & 6.0 & 61.9 & 1.9 \\
\hline 3 & 9.0 & 5.6 & 1.0 & 44.0 & 6.8 & 66.3 & 6.3 \\
\hline 4 & 9.0 & 5.2 & 1.0 & 40.6 & 6.8 & 62.6 & 2.5 \\
\hline 5 & 9.0 & 6.4 & 1.0 & 42.0 & 6.2 & 64.6 & 4.6 \\
\hline 6 & 9.0 & 6.4 & 1.0 & 41.0 & 6.2 & 63.5 & 3.4 \\
\hline 7 & 9.0 & 6.0 & 1.0 & 40.7 & 6.8 & 63.4 & 3.4 \\
\hline
\end{tabular}

${ }^{1}$ For the May 2001 TSLCC, FY 2001 costs have been included in historical costs. 
2 Includes $\$ 0.5$ billion in 180 (c) costs which in the TSLCC were included in PI\&I

${ }^{3}$ Reduced by $\$ 0.5$ billion in 180 (c) costs transferred to WAST

As can be seen from Table ES-3, the life cycle costs for the 7 scenarios are $\$ 1.9$ to $\$ 4.6$ billion higher than the May 2001 TSLCC. Repository costs are $\$ 2.7$ to $\$ 4.5$ billion higher. However, nearly all of the increase in repository costs result from the difference in assumed contingency factors between the May 2001 TSLCC ( $\sim 14 \%$ for repository costs) and this study. Table ES-4 shows a summary comparison of repository costs without contingency for the 7 scenarios and the TSLCC.

Table ES-4. Repository Base Cost Comparison for 97,800 MTHM Emplacement

\begin{tabular}{|c|c|c|}
\hline Scenario & Repository Cost (B 2002\$) & $\begin{array}{c}\text { Delta to May 2001 } \\
\text { TSLCC }\end{array}$ \\
\hline May 2001 TSLCC & 31.9 & 0.0 \\
\hline 1 & 31.5 & -0.4 \\
\hline 2 & 31.5 & -0.4 \\
\hline 3 & 34.1 & 2.2 \\
\hline 4 & 31.5 & -0.4 \\
\hline 5 & 32.6 & 0.7 \\
\hline 6 & 31.8 & -0.1 \\
\hline 7 & 31.6 & -0.3 \\
\hline
\end{tabular}

A detailed reconciliation of the costs for scenario 1 versus the May 2001 TSLCC showed that the principal cost reductions in scenario 1 result from lower repository $O \& M$ and design costs.

A parametric assessment of Fee Adequacy was performed for the 7 scenarios analyzed in this study utilizing data from the May 2001 TSLCC model (DOE 2001e), adjusted for the larger repository area. The results of the assessment indicated that there does not appear to be a Fee Adequacy concern with any of the scenarios.

\section{CONCLUSIONS AND RECOMMENDATIONS}

The overall conclusion of this study is that the repository design concept recommended for further study in the Design Evolution Study (Rowe 2002) is adaptable and appears to be sufficiently flexible to encompass a variety of receipt rates, emplacement rates, transportation options, and funding profiles. Other conclusions are as follows:

1. Peak and total Program costs during the pre-operations period (through 2010) were reduced by utilizing a phased repository construction concept. Scenario 1, which has receipt and emplacement assumptions similar to those in the May 2001 TSLCC (DOE 2001 e), reduced peak Program costs by $\$ 90$ million (6 percent) and total costs through 2010 by $\$ 1.0$ billion (12 percent) versus the SR design. Scenario 5 reduced peak costs by $\$ 570$ million (35 percent) and total costs by $\$ 2.6$ billion (29 percent), but at the cost of a 
substantial reduction in initial receipt capability. Note that without the assumed increase in contingency factors versus the May 2001 TSLCC, the cost differences for all scenarios would have been greater.

2. Repository design and construction costs represent about 24 percent of total Program costs through 2010. Therefore, even though these costs were reduced by almost 50 percent by phased construction in Scenario 1, the net reduction in total cost was only 12 percent.

3. The preliminary construction schedule developed for the Design Evolution Study, while supporting a 2010 operation date, does not support receipt of waste at the CRD target rates in 2010 (400 MTHM of CSNF).

4. Once adjusted for differing contingency factors, estimated total life cycle costs for the 7 implementation scenarios are not significantly different than for the SR design modeled in the May 2001 TSLCC, particularly given the large uncertainties in the cost estimates.

5. The Nuclear Waste Fund (NWF) Fee appears to be adequate for all of the scenarios.

6. The construction schedule developed for the Design Evolution Study identified a number of early construction activities that would improve confidence in meeting an operation date of 2010. Further evaluation is being performed as part of the Critical Decision 1 (CD-1) effort to determine the extent to which early construction activities may be required.

7. Construction and operation of the repository in a phased manner appears to be consistent with the current regulatory requirements in 10 CFR 63.

8. The phased repository construction concept appears to be adaptable to early waste receipt, assuming adequate funding and authorization.

9. The design concept analyzed in this study did not meet the constrained funding criterion of $\$ 600$ million/year from LA through 2010. Contributing factors were the need to support a rapid ramp-up in waste receipt rate through 2015 , and the fact that Balance-ofPlant (BOP) cost phasing was not evaluated. However, given the fact that repository design and construction costs represent about 24 percent of the total Program costs through 2010 , it is unlikely that the $\$ 600$ million/year goal can be met without reductions in Program costs other than design and construction.

10. The analysis of Scenario 3 involved a several-year moratorium on underground construction and emplacement after the filling of the test area in subsurface Panel 1. This required an assumption of either surface storage at the repository for defense wastes, or halting receipt of defense wastes during the emplacement moratorium. For the purposes of this study, it was assumed that surface storage of defense wastes would be employed. If such a feature were to be included in the repository design, storage casks for HLW and DSNF (including naval SNF) would need to be designed and licensed. 
11. The cost analyses performed for this design concept were only rough order of magnitude (ROM) estimates, in that there was little or no "bottoms up" cost analysis performed due to lack of design detail and time constraints. Therefore, the life cycle costs generated in this study are useful only for comparative purposes.

The following recommendations were developed from this study:

1. As part of the preliminary design process, further evaluation of the repository design concept and more detailed estimates of BOP facilities' cost and construction schedules will be required to more accurately determine annual costs through 2010 .

2. As part of the preliminary design process, further evaluation of the repository construction schedule should be performed to more accurately determine the need for early construction activities and the receipt rate in the early years of operation.

3. As the design is refined further, more comprehensive life cycle cost and Fee Adequacy analyses should be performed, including development of a more detailed O\&M cost model.

4. There is a need to evaluate other Program costs (besides repository design and construction), in order to further reduce the funding profile through 2010 . 
INTENTIONALLY LEFT BLANK 


\section{CONTENTS}

1. INTRODUCTION

$1.1 \quad$ PURPOSE

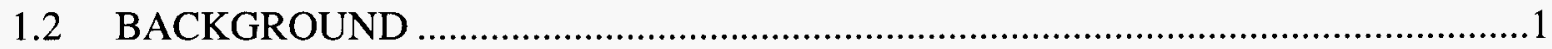

1.3 SCOPE

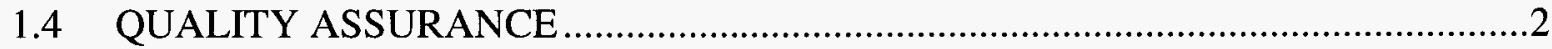

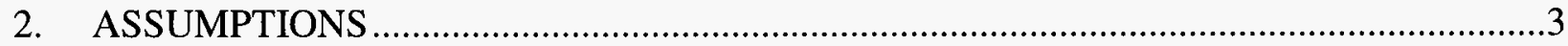

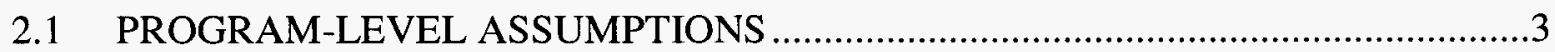

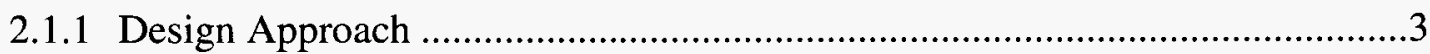

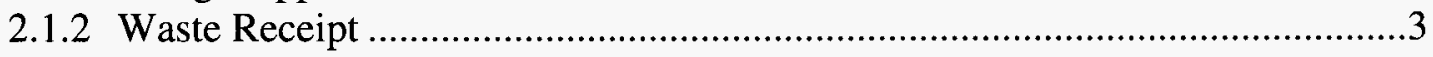

2.1.3 Waste Emplacement....................................................................................

2.1.4 Funding Profile and Cost Constraints ............................................................4

2.1.5 Limited Work Authorization, Regulatory Changes, and Program Redirection.4

2.1.6 Transportation ............................................................................................

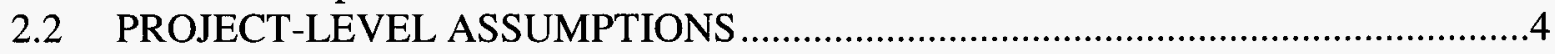

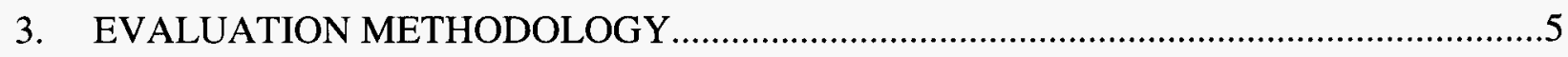

3.1 GENERAL EVALUATION PROCESS ………......................................................

3.2 USE OF SCENARIOS IN DESIGN EVALUATION ..................................................

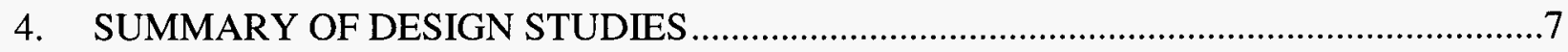

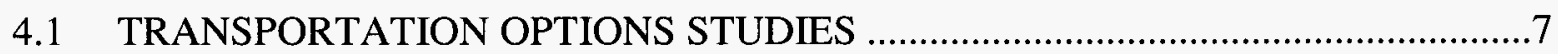

4.1.1 National Transportation Options Study …………...........................................

4.1.2 Nevada Transportation Options Study ...........................................................10

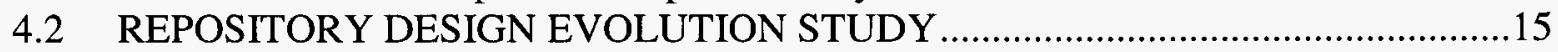

4.2.1 Repository Subsurface Design ....................................................................15

4.2.2 Surface Facilities..........................................................................................20

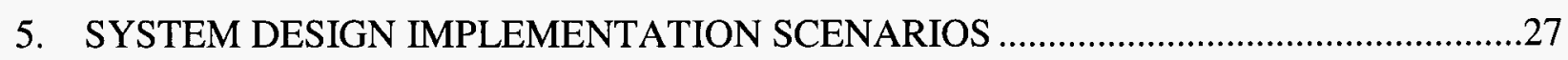

5.1 RECEIPT AND EMPLACEMENT SCENARIOS ....................................................27

5.1.1 Scenario 1 - Mostly Rail, Reference Receipt Rates.........................................27

5.1.2 Scenario 2 - Mostly Rail, Initial APR/ACR Receipt Rate .............................27

5.1.3 Scenario 3 - Mostly Rail, Reference Receipt Rate, Delayed Emplacement ...27

5.1.4 Scenario 4 - Mostly Rail, Accelerated Receipt and Emplacement Rate.........28

5.1.5 Scenario 5 - Initial Truck/Heavy Haul, Low Rate ............................................28

5.1.6 Scenario 6 - Initial Truck/Heavy Haul, High Rate ..........................................28

5.1.7 Scenario 7: Initial Truck/Heavy Haul, High Rate, 2 Year Rail Delay .............28

5.2 REPOSITORY DESIGN MODULE TIME-PHASING .............................................

5.2.1 Surface Facilities .................................................................................

5.2.2 Subsurface Facility ....................................................................................32

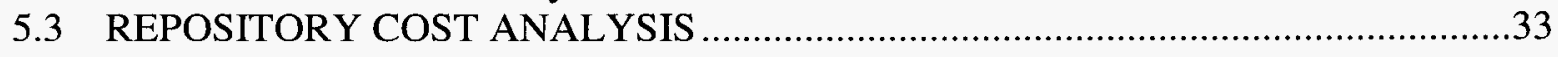

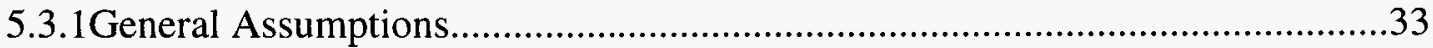

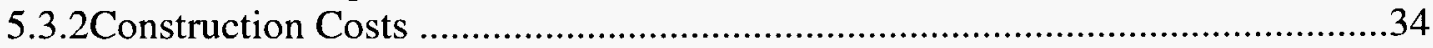


5.3.3 Operations and Maintenance Costs ...............................................................35

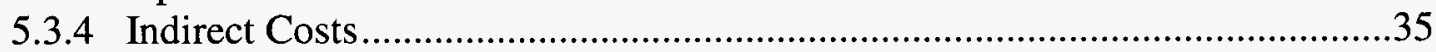

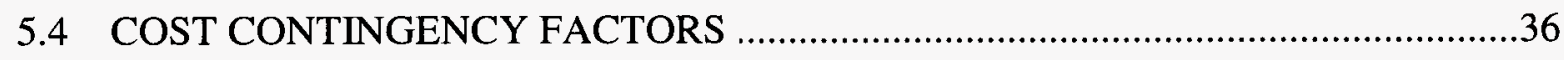

6. EVALUATION OF SYSTEM DESIGN IMPLEMENTATION SCENARIOS ....................37

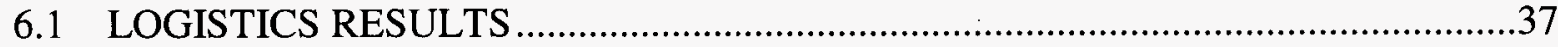

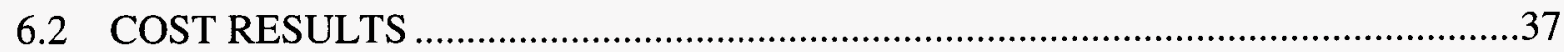

6.2.1 Costs for 70,000 MTHM Receipt and Emplacement .........................................37

6.2.2 Total Life Cycle Costs and Fee Adequacy …………......................................39

6.3 EVALUATION OF RESULTS VERSUS PROGRAMMATIC ASSUMPTIONS .....42

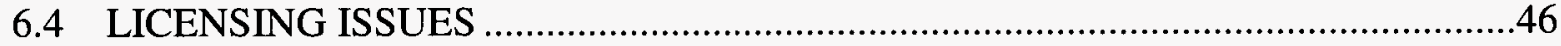

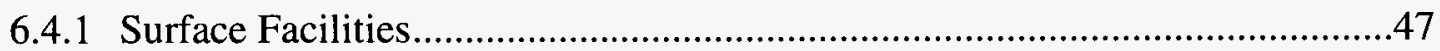

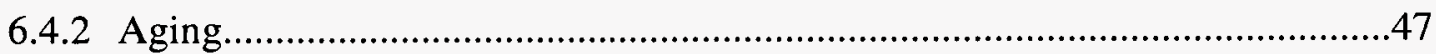

6.4.3 Design Implementation .................................................................................47

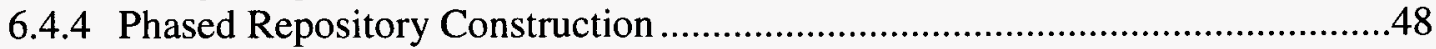

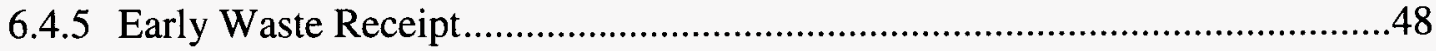

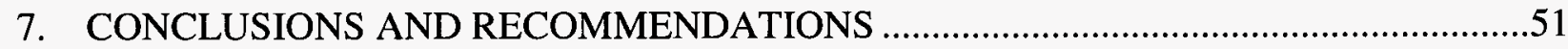

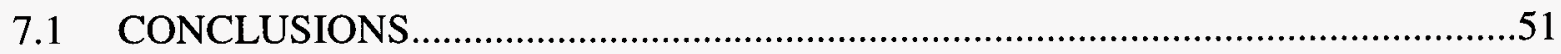

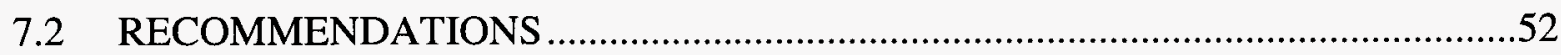

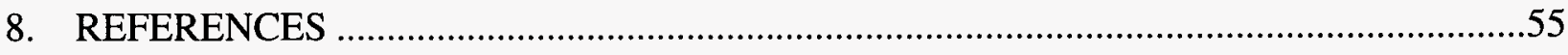

APPENDIX A - YFF10 CSNF SELECTION CRITERION ................................................... A-1

APPENDIX B - TRANSPORTATION SCENARIOS ANNUAL COSTS .................................B-1

APPENDIX C - RECEIPT AND EMPLACEMENT SCENARIOS ............................................

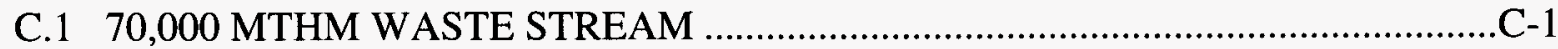

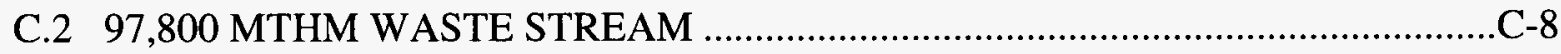

APPENDIX D - SUMMARY SYSTEM COST WORKSHEETS ………………………..... D-1

APPENDIX E - ANALYSIS OF STATUTORY AND REGULATORY FLEXIBILITY TO ACCOMMODATE A PHASED APPROACH TO REPOSITORY DEVELOPMENT .............E-1 


\section{TABLES}

Page

ES-1. Logistics Results .................................................................................................. ix

ES-2. CRWMS Future Costs, 2002-2020 (M 2002\$) ……………………………............... $\mathrm{x}$

ES-3. Total Life Cycle Cost for 97,800 MTHM Emplacement (B 2002\$) ................................... x

ES-4. Repository Base Cost Comparison for 97,800 MTHM Emplacement ............................... xi

1. CSNF Waste Stream Parameters, 63,000 MTHM …………………………………....... 7

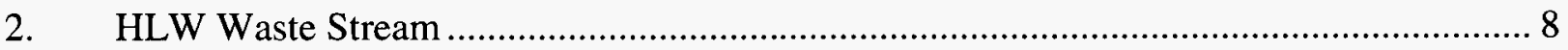

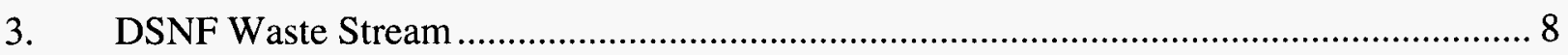

4. National Transportation Scenarios Selected for System Evaluation ................................. 9

5. Nevada Transportation Options Total Costs................................................................ 14

6. Site Access Road Costs..................................................................................... 14

7. Nevada Transportation Annual Costs (M 2001 \$) ......................................................... 14

8. Subsurface Facility Design Parameters ……………….............................................. 16

9. In-Drift Design Configuration Unit Costs .................................................................. 18

10. Purchase Cost Summary for OLT Equipment (M 2002\$) ............................................... 19

11. Surface Facility Construction Costs and Schedules....................................................... 21

12. Surface Facility Modular Capabilities ...................................................................... 22

13. Unit Costs for Storage Containers (M 2002\$) …….................................................... 24

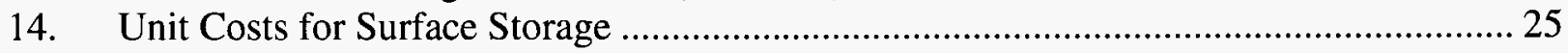

15. Receipt and Emplacement Scenarios - CSNF Parameters ........................................... 29

16. Receipt and Emplacement Scenarios - Defense Wastes Parameters.................................. 30

17. Surface and Subsurface Modules Development ............................................................... 33

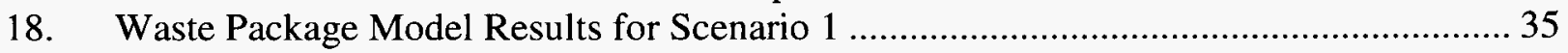

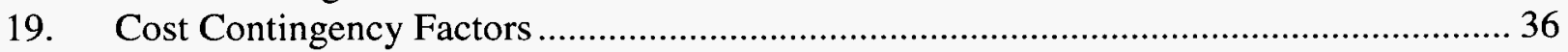

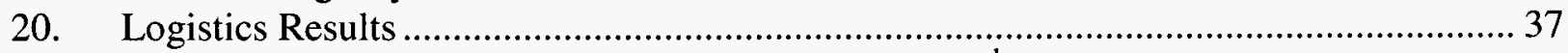

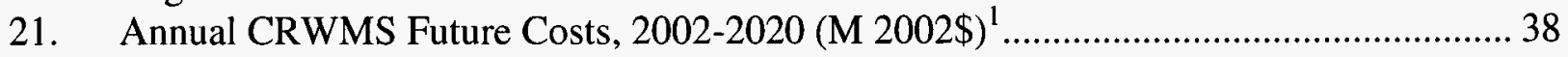

22. Life Cycle Cost for 70,000 MTHM Emplacement (B 2002\$) ........................................ 39

23. Total Life Cycle Cost for 97,800 MTHM Emplacement (B 2002\$) ................................ 40

24. Repository Base Cost Comparison for 97,800 MTHM Emplacement ...............................4 40

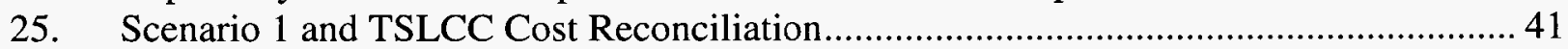

26. Evaluation of Design Implementation Versus Programmatic Assumptions..................... 43

B-1. Annual Costs for National Transportation Scenarios .................................................... C-1

C-1. Scenario 1 Nominal CSNF Receipt, Storage, and Emplacement Rates ......................... C-1

C-2. Scenario 1, 2, and 4 Defense Wastes Receipt/Emplacement Rates ................................ C-1

C-3. Scenario 2 Nominal CSNF Receipt, Storage, and Emplacement Rates .......................... C-2

C-4. Scenario 3 Nominal CSNF Receipt, Storage and Emplacement Rates .......................... C-3

C-5. Scenario 3 Nominal Defense Waste Receipt, Storage and Emplacement Rates ............. C-3

C-6. Scenario 4 Nominal CSNF Receipt, Storage and Emplacement Rates .......................... C-4

C-7. Scenario 5 Nominal Receipt, Storage and Emplacement Rates ……………………..... C-5

C-8. Scenario 6 Nominal Receipt, Storage and Emplacement Rates ................................... C-6

C-9. Scenario 7 Nominal Receipt, Storage and Emplacement Rates ……………............... C-7

C-10. Scenario 1 Nominal CSNF Receipt, Storage, and Emplacement Rates for 97,800

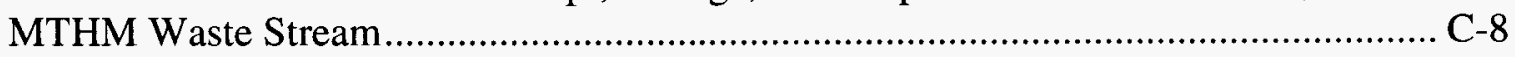




\section{TABLES (CONTINUED)}

Page

C-11. Scenario 1, 2, and 4 Nominal Defense Waste Receipt and Emplacement Rates for 97,800 MTHM Waste Stream ............................................................................. C-8

C-12. Scenario 2 Nominal CSNF Receipt, Storage, and Emplacement Rates for 97,800 MTHM Waste Stream........................................................................................ C-9

C-13. Scenario 3 Nominal CSNF Receipt, Storage, and Emplacement Rates for 97,800 MTHM Waste Stream ........................................................................................ C-10

C-14. Scenario 3 Nominal Defense Receipt, Storage, and Emplacement Rates for 97,800 MTHM Waste Stream.............................................................................. C-10

C-15. Scenario 4 Nominal CSNF Receipt, Storage, and Emplacement Rates for 97,800 MTHM Waste Stream

C-16. Scenario 5 Nominal CSNF and Defense Waste Receipt, Storage, and Emplacement Rates for 97,800 MTHM Waste Stream ................................................ C-12

C-17. Scenario 6 Nominal CSNF and Defense Waste Receipt, Storage, and Emplacement Rates for 97,800 MTHM Waste........................................................... C-13

C-18. Scenario 7 Nominal CSNF and Defense Waste Receipt, Storage, and Emplacement Rates for 97,800 MTHM Waste Stream .................................................. C-14 


\section{FIGURES}

Page

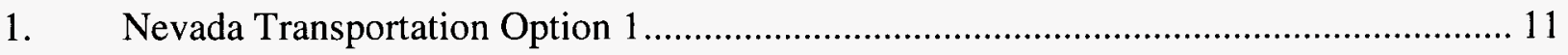

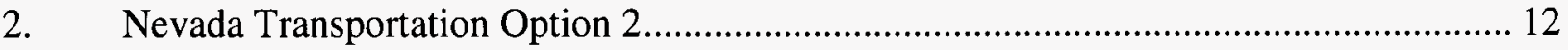

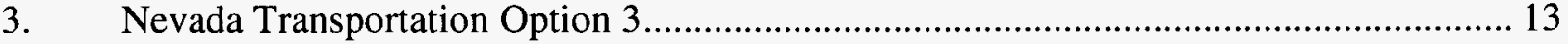

4. Recommended Modular Subsurface Layout............................................................. 16

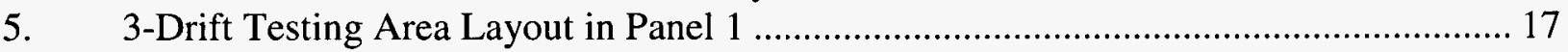

6. Recommended In-Drift Configuration.............................................................. 18

7. Recommended Waste Package Emplacement System .............................................. 19

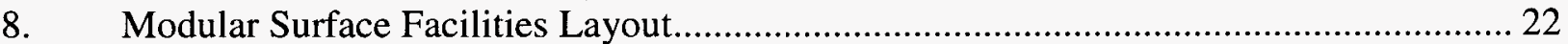

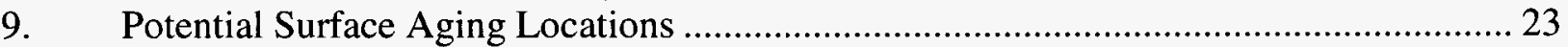


INTENTIONALLY LEFT BLANK 


\section{ACRONYMS AND ABBREVIATIONS}

APR/ACR Acceptance Priority Ranking/Acceptance Capacity Report

BOP Balance-of-Plant

BSC Bechtel SAIC Company, LLC

BWR Boiling Water Reactor

CA Construction Authorization

CALVIN CRWMS Analysis and Logistics Visually Interactive Model

CRD

CRWMS Requirements Document

CRWMS Civilian Radioactive Waste Management System

CSNF Commercial Spent Nuclear Fuel

DC Disposal Container

DOE U.S. Department of Energy

DPC Dual-Purpose Canister

DSNF DOE-Managed Spent Nuclear Fuel

DTS Dry Transfer System

ES\&H Environmental Safety and Health

FB Finishing Building

FEIS Final Environmental Impact Statement

FY Fiscal Year

G\&A General and Administrative

GA General Atomics

GROA Geologic Repository Operations Area

HH Heavy Haul

HLW High-Level Radioactive Waste

HTOM High Temperature Operating Mode

IAS Integrated Acceptance Schedule

INEEL Idaho National Environmental and Engineering Laboratory

LA License Application

LWT Legal Weight Truck

M\&O Management and Operating Contractor

MPC Multi-Purpose Canister

MRS Monitored Retrievable Storage

MTHM Metric Tons of Heavy Metal 


\section{ACRONYMS AND ABBREVIATIONS (CONTINUED)}

$\begin{array}{ll}\text { NRC } & \text { U.S. Nuclear Regulatory Commission } \\ \text { NDOT } & \text { Nevada Department of Transportation } \\ \text { O\&M } & \begin{array}{l}\text { Operations and Maintenance } \\ \text { OCRWM }\end{array} \\ \text { OLT } & \begin{array}{l}\text { Office of Civilian Radioactive Waste Management } \\ \text { PETT }\end{array} \\ \text { PI\&I } & \begin{array}{l}\text { Payments Equivalent to Taxes } \\ \text { PWR }\end{array} \\ \text { Program Integration and Institutional } \\ \text { QA } & \text { Quality Assurance } \\ \text { QC } & \text { Quality Control } \\ \text { RIMS } & \text { Regulatory, Infrastructure, and Management Support } \\ \text { SNF } & \text { Spent Nuclear Fuel } \\ \text { SR } & \text { Site Recommendation } \\ \text { SRS } & \text { Savannah River Site } \\ \text { SS } & \text { Stainless Steel } \\ \text { TDL } & \text { Technical Direction Letter } \\ \text { TSLCC } & \text { Total System Life Cycle Cost } \\ \text { TWP } & \text { Technical Work Plan } \\ \text { WAST } & \text { Waste Acceptance, Storage, and Transportation } \\ \text { WHF } & \text { Waste Handling Facility } \\ \text { WP } & \text { Waste Package } \\ \text { WTF } & \text { Waste Transfer Facility } \\ \text { WVDP } & \text { West Valley Demonstration Project } \\ \text { YFF10 } & \text { Youngest Fuel First Greater Than or Equal to 10 Years Old }\end{array}$




\section{INTRODUCTION}

\subsection{PURPOSE}

The purpose of this study is to respond to U.S. Department of Energy (DOE) Technical Direction Letter (TDL) 02-003 (Waisley 2001), which directs Bechtel SAIC Company, LLC (BSC) to complete a design study to recommend repository design options to support receipt and/or emplacement of any or all of the following: commercial spent nuclear fuel (CSNF), high-level radioactive waste (HLW), DOE-managed spent nuclear fuel (DSNF) (including naval spent nuclear fuel [SNF]), and immobilized plutonium (if available), as soon as practicable, but no later than 2010. From the possible design options, a recommended approach will be determined for further evaluation to support the preliminary design of the repository.

\subsection{BACKGROUND}

A repository development approach that includes modular repository design and construction may provide significant advantages in meeting Program schedules and provide the flexibility to address Program technical and regulatory issues. In addition, a phased development approach using modular design may reduce the near-term annual costs for repository design and construction. It is possible that annual funding for the Program will be constrained until a repository is constructed and begins operation, thus putting a priority on repository designs that can be constructed under reduced funding levels.

\subsection{SCOPE}

This study integrates the results of the repository Design Evolution Study (Rowe 2002) with supporting studies concerning national transportation options (BSC 2002b) and Nevada transportation options (Gehner 2002). The repository Design Evolution Study documents the processes used to re-evaluate the design, construction, operation, and cost of the repository in response to TDL $02-003$, and to determine possible repository conceptual design options. The transportation studies evaluate the national and Nevada transportation options that support the repository conceptual design options. An evaluation methodology was established, based on Program-level requirements developed for the study in reference BSC 2001a, to allow the repository and system design options to be evaluated on a consistent basis. The transportation options and the design components were integrated into system design implementation options, which were evaluated using 7 receipt and emplacement scenarios. The scenarios tested the ability of the design concept to adapt to changes in funding, waste receipt rate, and Nevada rail transportation availability. The results of the evaluation (in terms of system throughput, cost, and schedule) were then compared to the Program-level requirements, and recommendations for design alternatives, requirements changes, or further evaluation were developed.

This study includes a number of scenarios that are not consistent with the target acceptance rates in the Civilian Radioactive Waste Management System Requirements Document (CRD) (DOE 2001a, Table 1) for any of the waste forms planned for disposal in a repository. This does not imply in any way that any changes to the target acceptance rates are being contemplated. The focus of this study is not on evaluating and selecting operating scenarios (including acceptance rates), but rather on creating a system design that is flexible enough to adapt to a wide range of possible future technical, schedule, licensing, and funding constraints. This is based on 
recognition (confirmed by historical experience) that many factors, such as funding, that could affect the achievability of preferred scenarios, are outside of the Program's control.

\subsection{QUALITY ASSURANCE}

An Activity Evaluation was performed for this activity in accordance with AP-2.21Q, Quality Determinations and Planning for Scientific, Engineering, and Regulatory Compliance Activities, and is attached to the Technical Work Plan (TWP) (BSC 2002a). The Activity Evaluation determined that this study is not quality affecting; however, it was performed and documented using applicable Quality Assurance procedures as guidance, as described in the TWP. 


\section{ASSUMPTIONS}

This section describes the assumptions used in the analysis.

\subsection{PROGRAM-LEVEL ASSUMPTIONS}

This section summarizes the Program-level assumptions used in the study. These assumptions are taken from the White Paper on Program-level assumptions (BSC 2001a). The rationales for these assumptions are given in BSC 2001a.

\subsubsection{Design Approach}

A. The study shall focus on flexible modular design options that could support a staged repository development approach.

B. The repository design shall have the flexibility to accommodate early receipt, assuming adequate funding and authorization are available.

C. An initial subsurface performance confirmation and test facility (hereafter called the Demonstration Stage) shall be included as an option.

D. Repository design and operations assumptions shall be bounded by values assumed in the Final Environmental Impact Statement (FEIS).

E. The design shall retain the capability for either a high- or low-temperature post-closure thermal mode.

\subsubsection{Waste Receipt}

A. The design shall support waste receipt as soon as practicable, but no later than 2010 .

B. The repository shall have the initial capability to receive annually at least one waste package (WP) quantity of CSNF and one shipment of naval SNF. Initial receipt of HLW, DSNF (excluding naval SNF), and immobilized plutonium (if available) shall be a goal assuming adequate funding is available.

\subsubsection{Waste Emplacement}

A. Waste emplacement is decoupled from waste receipt.

B. A high priority goal of the study is to develop a design concept that could allow initial emplacement of some CSNF (plus any or all of the other waste types described in 2.1.2.B, if possible) by 2010 , even under the constrained funding assumption in section 2.1.4. 
C. The design of the repository will be based on a capacity of 70,000 metric tons of heavy metal (MTHM) (63,000 MTHM CSNF, 7,000 MTHM defense wastes), but shall not preclude receipt and emplacement of up to the maximum waste quantity described in the FEIS.

D. As a minimum, the initial emplacement rate shall support a subsurface testing facility.

\subsubsection{Funding Profile and Cost Constraints}

The following constrained funding assumptions shall be used:

- A maximum of $\$ 400$ million/year (Program total) through LA

- A maximum of $\$ 600$ million/year from LA through 2010

The design shall have the flexibility to ramp up to the target receipt schedule in the current CRD Table 1, assuming additional funding is available. The design shall not preclude the ability to expand receipt rates to levels exceeding the maximum target rate in the CRD.

\subsubsection{Limited Work Authorization, Regulatory Changes, and Program Redirection}

The design solutions shall not be predicated on the receipt of a Limited Work Authorization (LWA), regulatory changes, or legislative redirection of the Program. The design must be flexible enough to accommodate early construction of non-nuclear portions of the facility outside the Geologic Repository Operations Area (GROA), assuming adequate funding and authorization.

\subsubsection{Transportation}

A. There will be no requirement for availability of rail transportation prior to start of operations.

B. Repository design solutions shall be integrated with the national transportation system.

\subsection{PROJECT-LEVEL ASSUMPTIONS}

The design studies that comprise the Design Evaluation Study (Board et al. 2002; Brown 2002; Linden 2002; McDaniel 2002; Silva and Stanley 2002) and the transportation options studies (BSC 2002b; Gehner 2002) contained a number of Project-related assumptions. These assumptions are summarized in the Design Evolution Study Summary (Rowe 2002) and the transportation options studies. Two additional assumptions were made for this study regarding the repository thermal operating mode and CSNF aging:

A. A high-temperature subsurface thermal operating mode (HTOM) was assumed for all scenarios, to be consistent with the Site Recommendation (SR) design reflected in the May 2001 Total Life Cycle Cost estimate (TSLCC) (DOE 2001b).

B. The thermal operating mode was assumed to require 1,000 MTHM of surface aging for CSNF. This allows for a more consistent cost comparison with the SR surface facility design, which included a 5,000 MTHM blending pool. 


\section{EVALUATION METHODOLOGY}

This section describes the evaluation methodology used for the study.

\subsection{GENERAL EVALUATION PROCESS}

In order to provide as much consistency as possible between the design studies, standard evaluation criteria and a recommended evaluation methodology were developed. This methodology is described in detail in the Design Evolution Study Summary (Rowe 2002, Appendix A). The evaluation criteria used in the design studies were grouped into the following general categories:

- Pre- and Post-Closure Health and Safety (public and workers)

- Flexibility

- Licensability and Regulatory Acceptance

- Receipt/Emplacement Capability

- Schedule

- Cost

- Non-Safety (Programmatic) Risk (e.g., constructability, operability, maintainability)

- Compatibility with Other Design Components

- Public Confidence

- Use of Existing Studies and Analyses

Within these general categories, specific evaluation criteria were identified for each study. The Program-level assumptions provided in the TDL (Waisley 2001) were factored into the specific evaluation criteria, along with project-level assumptions developed for the individual studies. The specific evaluation criteria were then classified as either "needs" (i.e., required to be satisfied), or "wants" (desirable to be satisfied). The design alternatives developed for each study were then evaluated versus the evaluation criteria, to determine the recommended alternative.

\subsection{USE OF SCENARIOS IN DESIGN EVALUATION}

In this study, the design recommendations from the Design Evolution Study are evaluated for each of the selected operational scenarios. However, many of the evaluation criteria described in the Design Evolution Study Summary (Rowe 2002, Appendix A) are not applicable to this scenario-based analysis. For example, one would not expect any scenario-related differences for postclosure public health and safety. In contrast, one would expect scenario-related effects on criteria such as Schedule, Receipt/Emplacement Capabilities, Cost, and Flexibility.

Therefore, for this study, a subset of the evaluation criteria described above was selected that consists of the Program-level assumptions described in Section 2. The results of the evaluation 
are described in Section 6.3. In addition, potential licensing issues raised either in the design studies or in this study are discussed in Section 6.4. 


\section{SUMMARY OF DESIGN STUDIES}

This section summarizes the results of the Repository Design Evolution Study (Rowe 2002) and the transportation options studies (BSC 2002b; Gehner 2002) that were performed to provide input to the system analysis.

\subsection{TRANSPORTATION OPTIONS STUDIES}

This section describes the results of the National Transportation Options study (BSC 2002b) and the Nevada Transportation Options study (Gehner 2002).

\subsubsection{National Transportation Options Study}

The purpose of this study was to identify and analyze the throughput and costs of national transportation options that will be used as input to the Modular Design Implementation System Evaluation for License Application.

\subsubsection{Waste Stream}

A 70,000 MTHM waste stream was used as the basis for this analysis, consisting of 63,000 MTHM of CSNF and 7,000 MTHM of defense wastes. The CSNF characteristics are shown in Table 1.

Table 1. CSNF Waste Stream Parameters, 63,000 MTHM

\begin{tabular}{|c|c|c|c|c|c|c|c|c|c|c|}
\hline & \multicolumn{5}{|c|}{ BWR $^{1}$} & \multicolumn{5}{|c|}{ PWR $^{2}$} \\
\hline & $\begin{array}{l}\text { Age } \\
\text { (yrs) }\end{array}$ & $\begin{array}{l}\text { Burnup } \\
\text { (GW/MT) }\end{array}$ & $\begin{array}{c}\text { Enrich. } \\
(\%)\end{array}$ & $\begin{array}{l}\% \text { of } \\
\text { Assm }\end{array}$ & $\begin{array}{c}\text { MTI } \\
\text { Assm }\end{array}$ & $\begin{array}{l}\text { Age } \\
\text { (yrs) }\end{array}$ & $\begin{array}{l}\text { Burnup } \\
\text { (GW/MT) }\end{array}$ & $\begin{array}{c}\text { Enrich. } \\
(\%)\end{array}$ & $\begin{array}{c}\% \text { of } \\
\text { Assm }\end{array}$ & $\begin{array}{c}\text { MT/ } \\
\text { Assm }\end{array}$ \\
\hline Average & 16.5 & 42 & 3.7 & 57.5 & 0.174 & 17.1 & 46 & 4.3 & 42.5 & 0.433 \\
\hline Maximum & 56 & 66 & 4.8 & $\mathrm{~N} / \mathrm{A}$ & $N / A$ & 59 & 71 & 5.0 & N/A & N/A \\
\hline Minimum & 5 & 0 & 0.7 & N/A & N/A & 5 & 2 & 0.3 & N/A & $N / A$ \\
\hline
\end{tabular}

'BWR = boiling water reactor

${ }^{2}$ PWR = pressurized water reactor

Note: Data taken from reference BSC $2002 b$, Table 3.

The CSNF selection criterion used in this analysis is "Youngest Fuel First Greater than or Equal to 10 Years Old" (YFF10), which is described in Appendix A. This selection criterion was chosen to maintain consistency with the assumptions used in the waste stream for the May 2001 TSLCC (DOE 2001b). The YFF10 criterion produces a "best estimate" waste stream from a standpoint of transportation cask shipments and CSNF parameters at arrival. For each scenario, the CALVIN Version 3.1 computer code (BSC 2001c) was used to calculate the CSNF accepted and shipped to the repository. The reference annual CSNF acceptance rates are based on the target acceptance rates given in the CRD (DOE 2001a, Table 1). 
The defense waste stream modeled in this report was derived from the DOE/EM Integrated Acceptance Schedule (IAS) v1.08 dated June 29, 2001 (Bebee 2001). This draft shipping schedule for DSNF, HLW, and Navy waste has the latest (most accurate) projected inventories and dates of availability.

For the 70,000 MTHM waste stream, the first 4,667 MTHM of HLW and 2,333 MTHM of DSNF from the full waste stream were selected. For purposes of converting the HLW allocation to number of canisters, it was assumed that each HLW canister contains 0.5 MTHM (DOE 1999a, Appendix A). All naval and Idaho National Engineering and Environmental Laboratory (INEEL) DSNF listed in the IAS was included in the 2,333 MTHM allocated to DSNF, to be consistent with the assumption that all DSNF must be removed from INEEL by 2035 . No West Valley Demonstration Project (WDVP) HLW was assumed to be in the first 4,667 MTHM of HLW. In addition, for Savannah River (SRS), no HLW canisters containing immobilized Plutonium were assumed to be part of the total SRS HLW canisters.

Tables 2 and 3 describe the HLW and DSNF waste streams for both the full and 70,000 MTHM cases.

Table 2. HLW Waste Stream

\begin{tabular}{|c|c|c|c|c|}
\hline \multirow{2}{*}{ Waste Site } & \multicolumn{2}{|c|}{ Full Waste Stream } & \multicolumn{2}{c|}{ 70,000 MTHM Waste Stream } \\
\cline { 2 - 5 } & MHTM $^{1}$ & Canisters & MHTM $^{1}$ & Canisters \\
\hline Hanford & $6,099.0$ & 12,198 & $2,706.5$ & 5,413 \\
\hline INEEL & 660.5 & 1,321 & 232.5 & 465 \\
\hline Savannah River & $2,935.5$ & 5.871 & $1,728.0$ & 3,456 \\
\hline WVDP & 639.9 & 300 & 0 & 0 \\
\hline Total & $10,334.9$ & 19,690 & 4,667 & 9,334 \\
\hline
\end{tabular}

1 Assumes 0.5 MTHM per canister for defense wastes, and 2.13 MTHM per canister for West Valley Note: Data taken from reference BSC $2002 b$, Table 4

Table 3. DSNF Waste Stream

\begin{tabular}{|c|c|c|}
\hline \multirow{2}{*}{ Waste Site } & \multicolumn{2}{|c|}{ Canisters } \\
\cline { 2 - 3 } & Full Waste Stream & $\mathbf{7 0 , 0 0 0}$ MTHM Waste Stream \\
\hline Hanford - 15 ft. & 344 & 344 \\
\hline Hanford - MCO & 441 & 351 \\
\hline INEEL - Naval & 300 & 300 \\
\hline INEEL - 10 ft. & 984 & 984 \\
\hline INEEL - 15ft. & 619 & 619 \\
\hline SRS - 10 ft. & 400 & 400 \\
\hline Total & 3,088 & 2,998 \\
\hline
\end{tabular}

Note: Data taken from reference BSC $2002 \mathrm{~b}$, Table 5 


\subsubsection{Transportation Cask Options}

This section discussed transportation cask alternatives, including some that are not included in the standard cask fleet assumed in the TSLCC. These alternatives included:

- Legal Weight Truck (LWT) casks for HLW and DSNF

- LWT casks for canistered CSNF

It was concluded that LWT casks could be developed and procured for these waste forms by 2010 , although uncertainties exist with regard to costs and certification/procurement schedules.

\subsubsection{National Transportation Scenarios}

A total of 27 transportation scenarios were developed in the study. Of these 27 scenarios, 6 were selected for use in the system-level evaluation. These transportation scenarios are described in Table 4.

Table 4. National Transportation Scenarios Selected for System Evaluation

\begin{tabular}{|c|c|c|c|c|c|c|}
\hline \multirow[t]{2}{*}{ Scenario } & \multirow{2}{*}{$\begin{array}{c}\text { Shipping } \\
\text { Mode } 2010- \\
14\end{array}$} & \multicolumn{2}{|c|}{ CSNF Rate (MTHM/yr) } & \multirow{2}{*}{$\begin{array}{c}\text { HLW Rate } \\
\text { (MTHM/yr) } \\
2010-14\end{array}$} & \multirow{2}{*}{$\begin{array}{l}\text { DSNF Rate } \\
\text { (Can/yr) } \\
2010-14\end{array}$} & \multirow{2}{*}{$\begin{array}{c}\text { CSNF } \\
\text { Selection } \\
\text { Criterion }\end{array}$} \\
\hline & & 2010-14 & 2015- & & & \\
\hline $1 \mathrm{~B}$ & Mostly Rail & $400,600,900, \ldots$ & $\begin{array}{c}900,900,900 \\
900,900,1800 \\
2200,2600 \\
3000,3600 \ldots\end{array}$ & Reference $^{3}$ & Reference $^{3}$ & YFF10 \\
\hline $3 B$ & Mostly Rail & Reference $^{2}$ & Reference $^{2}$ & Reference ${ }^{3}$ & Reference $^{3}$ & YFF10 \\
\hline $4 \mathrm{~A}$ & Mostly Rail & Ref. $+33.3 \%$ & 4000 & Reference $^{3}$ & Reference $^{3}$ & YFF10 \\
\hline $5 A$ & $\mathrm{LWT}^{1}$ & $50,100, \ldots$ & $\begin{array}{c}400,600,1200 \\
2000,3000 \\
3600, \ldots\end{array}$ & $10,20, \ldots$ & $5,7,10,10,16 .$. & YFF10 \\
\hline $7 A$ & $\mathrm{LWT}^{1}$ & $200,400, \ldots$ & $\begin{array}{c}400,600,1200 \\
2000,3000 \\
3600, \ldots\end{array}$ & $40,80, \ldots$ & $\begin{array}{c}11,19,22,22,28 \\
\ldots\end{array}$ & YFF10 \\
\hline 7D & $\mathrm{LWT}^{1}$ & $200,400^{5}$ & Reference $^{6}$ & $20,40^{5}$ & $\begin{array}{c}11,19,22,22,28 \\
\ldots\end{array}$ & YFF10 \\
\hline
\end{tabular}

1 LWT mode includes limited heavy haul of naval SNF

2 Reference CSNF rates are the target rates used in the TSLCC analysis (see Appendix C, Table C-1)

${ }^{3}$ Reference defense rates are the rates defined in the IAS (see Appendix C, Table C-2)

4 See Appendix A for definition of criteria

5 2010-11 only for Scenario 7D

$62012+$ for Scenario 7D

The annual costs developed for these scenarios are given in Appendix B. These costs include a 25 percent contingency for both capital and labor costs. 


\subsubsection{Nevada Transportation Options Study}

This study (Gehner 2002) evaluated a number of scenarios for transporting SNF and HLW, within Nevada, to the repository at Yucca Mountain. These scenarios include use of legalweight truck (LWT), rail, and limited heavy-haul $(\mathrm{HH})$ transport. The study also addresses infrastructure upgrades.

The first scenario (Option 1) provides rail access to the repository site by 2010 , when the surface facilities are ready to receive the waste. The initiation of rail construction for Option 1 would be required by early Fiscal Year (FY) 2007 or about one year prior to repository construction authorization.

The second scenario (Option 2) considers a phased approach to having rail access to the repository by 2015 , with limited $\mathrm{HH}$ transport of Navy rail casks during the initial five years. This approach addresses constrained funding during repository construction where approximately $95 \%$ of the cost to design and construct the railroad is deferred until after 2010 . The use of limited HH transport requires an intermodal transfer of the shipping cask from a railcar to a $\mathrm{HH}$ transporter at the mainline railroad, a road from the transfer location to an existing highway, and upgrading of the highway between the transfer location and the repository site. This mode of transport also requires a Nevada Department of Transportation (NDOT)issued heavy-haul permit for each movement of the HH transporter on the highway. Note that costs for a $\mathrm{HH}$ transfer station at the repository are included in the surface facilities costs developed in Section 4.2.2.1.

The third scenario (Option 3) delays rail access to the repository until 2012, also with limited $\mathrm{HH}$ transport of Navy rail casks during the initial two years. This approach addresses the impact of not starting the branch rail line construction until DOE receives repository construction authorization in 2008. This use of limited $\mathrm{HH}$ has the same requirements as identified in Option 2.

Also discussed in this study (Gehner 2002) are three alternatives for a site access road from U.S. 95 to the repository site. The function of the site access road is to support repository construction, operations, and waste receipt. Alternatives 1 and 2 identify a new road approximately 20 miles long that starts from U.S. 95, about one mile west of the Gate 510 entrance road, and proceeds to the repository site along the west side of Forty Mile Wash. The difference between the two alternatives is that Alternative 1 includes an NDOT scope to design and construct an interchange at U.S. 95, whereas Alternative 2 requires that trucks cross the highway. Alternative 3 discusses using the existing Gate 510 entrance and upgrading the existing site roads to accommodate heavy-haul as well as the other site traffic. Alternative 1 was recommended, as it provides the greatest level of safety, a low level of cost and schedule risk, and is likely to be preferred by NDOT. In comparison to the new branch rail line, the site access road is not a major cost driver.

Figures 1 - 3 show the development schedules for the 3 Nevada transportation options. Table 5 summarizes the total costs of the 3 options. Table 6 summarizes the costs of the recommended 


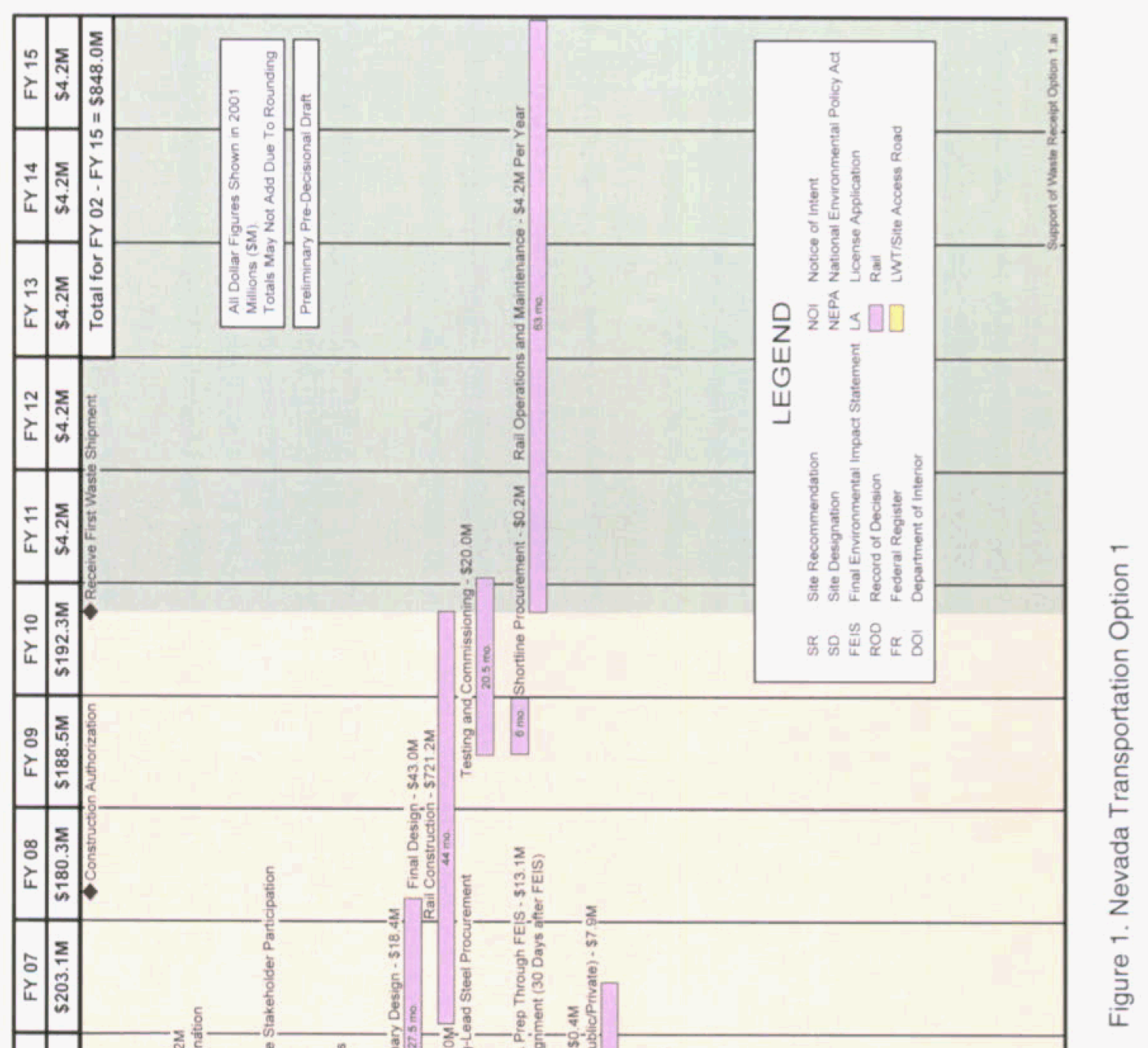




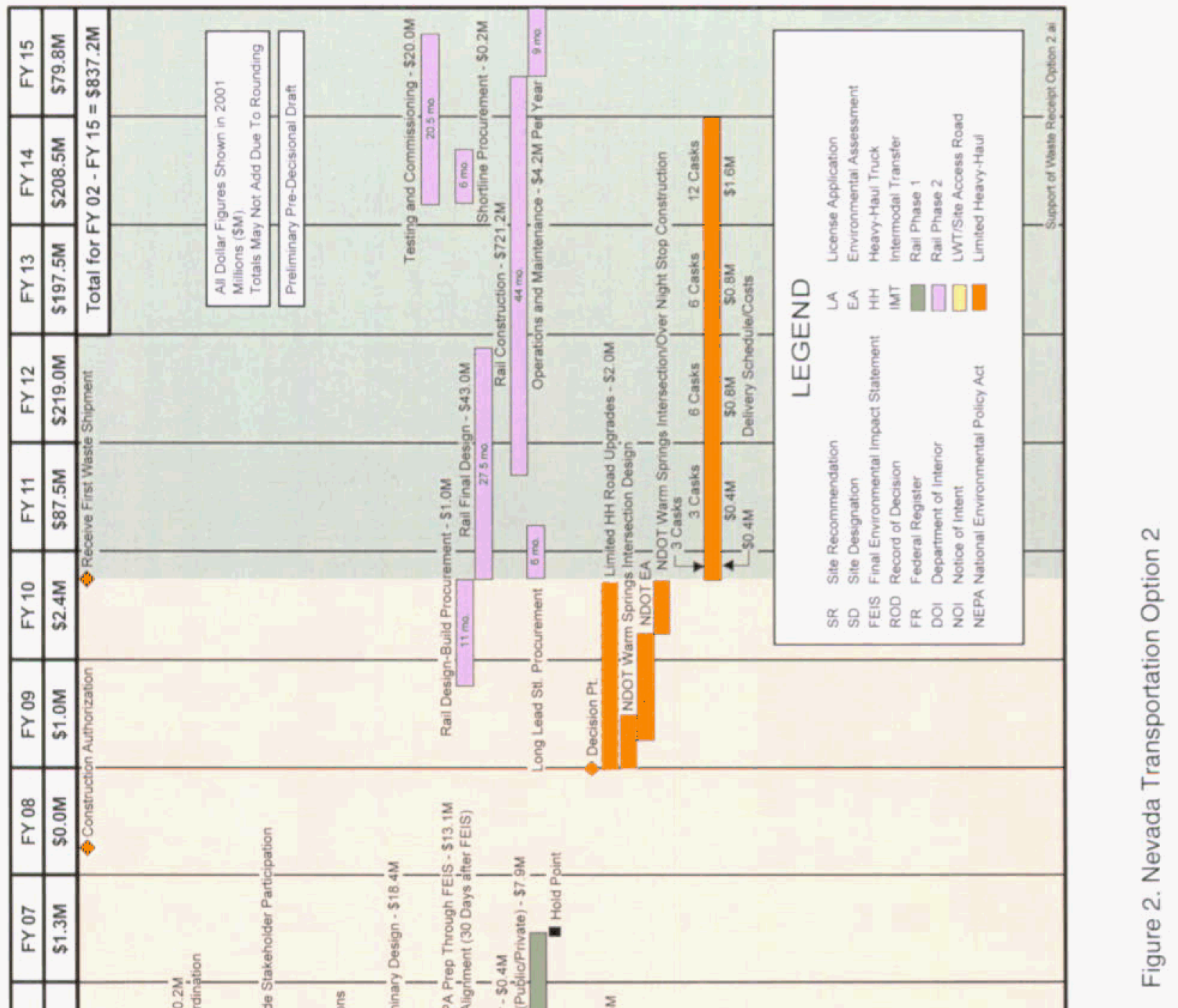




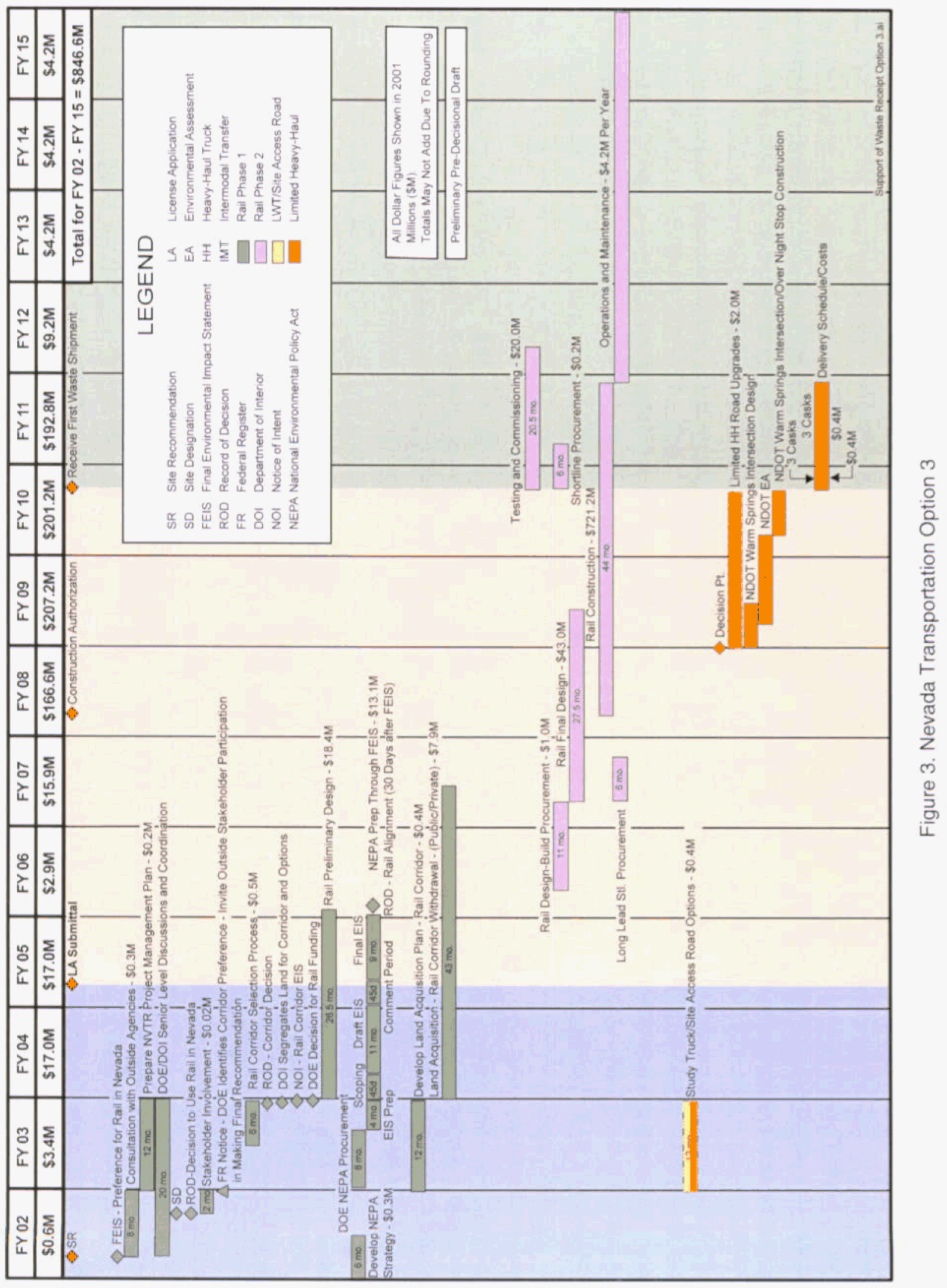


site access road alternative. Table 7 shows the annual development costs, including the site access road development, for the 3 options. These costs include a 25 percent contingency. Note that the schedules shown in Figures $1-3$ were developed under the assumption that transportation operations would begin in June 2010 (consistent with the May 2001 TSLCC [DOE $2001 \mathrm{~b}]$ ). Preliminary construction schedules developed for the Design Evolution Study (Rowe 2002) resulted in an initial repository operation date of December 2010 (see Section 5.2). This may result in a small inconsistency in Nevada transportation 2010 costs.

Table 5. Nevada Transportation Options Total Costs

\begin{tabular}{|c|c|c|c|}
\hline \multirow[b]{2}{*}{ Cost Category } & \multicolumn{3}{|c|}{ Costs in 2001 Dollars (Millions) ${ }^{1}$} \\
\hline & Option 1 & Option 2 & Option 3 \\
\hline Design, Acquisition, and Construction & 826.9 & 829.0 & 829.0 \\
\hline Heavy Haul Operations and Maintenance (per cask) & 0 & 0.1 & 0.1 \\
\hline Rail Operations and Maintenance (per year) & 4.2 & 4.2 & 4.2 \\
\hline
\end{tabular}

These costs are escalated to 2002 dollars for this analysis using an escalation factor of 1.02

Note: Data taken from reference Gehner 2002, Tables 1 - 3

Table 6. Site Access Road Costs

\begin{tabular}{|l|c|}
\hline \multicolumn{1}{|c|}{ Cost Component } & Cost (M 2001\$) \\
\hline Site Access Road Construction & 36.3 \\
\hline U.S. 95 Interchange Construction & 13.8 \\
\hline Annual Maintenance (per year) & 0.1 \\
\hline Overlay (every 8 Years) (per application) & 1.9 \\
\hline
\end{tabular}

These costs are escalated to 2002 dollars for this analysis using an escalation factor of 1.02

Note: Data taken from reference Gehner 2002, Table 5

Table 7. Nevada Transportation Annual Costs (M $2001 \$)^{1}$

\begin{tabular}{|c|c|c|c|c|}
\hline Fiscal Year & Option 1 & Option 2 & Option 3 & Site Access Road \\
\hline 2002 & 0.6 & 0.6 & 0.6 & 0 \\
\hline 2003 & 3.4 & 3.4 & 3.4 & 0 \\
\hline 2004 & 17.0 & 17.0 & 17.0 & 14.3 \\
\hline 2005 & 18.0 & 17.0 & 17.0 & 14.3 \\
\hline 2006 & 23.7 & 2.2 & 2.9 & 14.3 \\
\hline 2007 & 203.1 & 1.3 & 15.9 & 7.2 \\
\hline 2008 & 180.3 & 0.0 & 166.6 & 0.1 \\
\hline 2009 & 188.5 & 1.0 & 207.2 & 0.1 \\
\hline 2010 & 192.3 & 2.4 & 201.2 & 0.1 \\
\hline 2011 & 4.2 & 87.5 & 192.8 & 0.1 \\
\hline 2012 & 4.2 & 219.0 & 9.2 & 0.1 \\
\hline
\end{tabular}


Table 7. Nevada Transportation Annual Costs (M 2001 \$) (Continued)

\begin{tabular}{|c|c|c|c|c|}
\hline Fiscal Year & Option 1 & Option 2 & Option 3 & Site Access Road \\
\hline 2013 & 4.2 & 197.0 & 4.2 & 0.1 \\
\hline 2014 & 4.2 & 208.5 & 4.2 & 0.1 \\
\hline 2015 & 4.2 & 79.8 & 4.2 & $1.9^{2}$ \\
\hline $2016+$ & 4.2 & 4.2 & 4.2 & $0.1^{1}$ \\
\hline
\end{tabular}

These costs are escalated to 2002 dollars for this analysis using an escalation factor of 1.02

$21.9 \mathrm{M}$ every 8 years for road overlay

Note: Data taken from reference Gehner 2002, Tables A-1 to A-4

\subsection{REPOSITORY DESIGN EVOLUTION STUDY}

This section summarizes the results of the Repository Design Evolution Study (Rowe 2002), including the design component sub-studies (Board et al. 2002; Brown 2002; Linden 2002; McDaniel 2002; Silva and Stanley 2002), and the resulting repository conceptual design options.

\subsubsection{Repository Subsurface Design}

This section summarizes the results of the repository sub-studies addressing underground layout, in-drift configuration, and WP emplacement.

\subsubsection{Subsurface Layout}

The Underground Layout study (Board et al. 2002) provides the results of a reevaluation of the siting footprint, horizon selection, and underground layout of the proposed repository at the Yucca Mountain Project site.

An examination of the repository horizon selection was performed to determine if there was sufficient justification in altering the current SR horizon selection. It was determined that the current SR horizon selection, with minor modifications to adjust to the new siting footprint, was the best overall alternative.

With the horizon selected, the layout of the SR design was reexamined. It was proposed to alter the design concept to a repository composed of a number of panels that have shorter emplacement drifts, can be constructed more rapidly, and provide flexibility to adjust the repository design over time, as one need not "commit" to development of a large single panel at the earliest stages of construction. This layout additionally provides greater control of separation of the construction and emplacement functions, allows for somewhat simpler forced ventilation control, and facilitates performance confirmation testing within the center of the repository area. Since the layout is constructed in a phased manner over time, it was possible to incorporate a performance confirmation testing area into the overall layout while meeting the 2010 emplacement goal. Within the repository siting footprint it is possible to provide approximately $83,900 \mathrm{~m}$ of usable emplacement drift in four panels, which is sufficient to emplace 70,000 
MTHM of waste. Additional expansion area consisting of approximately 16,000 m of usable drift length is available in a fifth panel, if necessary.

Figure 4 shows the recommended repository footprint and subsurface layout. Table 8 lists the key design parameters for the subsurface facility.

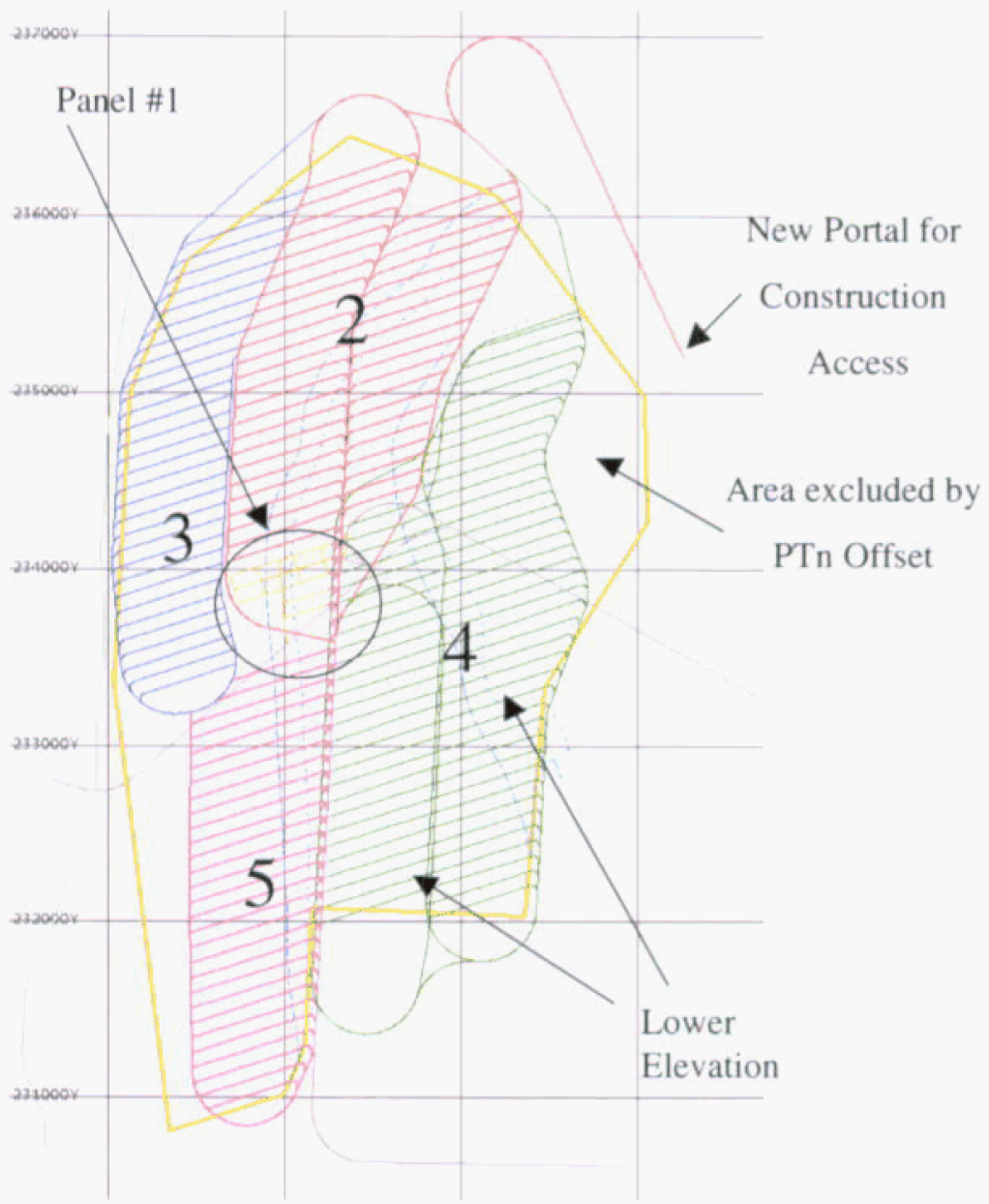

Figure 4. Recommended Modular Subsurface Layout

Table 8. Subsurface Facility Design Parameters

\begin{tabular}{|c|c|c|c|c|}
\hline Panel & $\begin{array}{c}\text { Usable } \\
\text { Emplacement Drift } \\
\text { Length }(m)^{1}\end{array}$ & $\begin{array}{l}\text { Construction } \\
\text { Schedule } \\
\text { (Months) }^{2}\end{array}$ & $\begin{array}{l}\text { Direct Cost } \\
\text { (M 2002\$) }^{3}\end{array}$ & $\begin{array}{l}\text { Distributables \& } \\
\text { Field Costs } \\
\text { (M 2002\$) }\end{array}$ \\
\hline 1 & 4,092 & $35^{4}$ & 216 & 0.6 \\
\hline 2 & 24,229 & 124 & 1,117 & 7.9 \\
\hline 3 & 17,490 & 105 & 559 & 4.1 \\
\hline 4 & 38,074 & 182 & 1,342 & 10.7 \\
\hline 5 & 16,063 & $\sim 101^{5}$ & 618 & 3.9 \\
\hline Total & 99,921 & & & \\
\hline
\end{tabular}


1 Taken from reference Board et al. 2002, Table 5 - 1

2 Taken from reference Board et al. 2002, Figures 5-8 and 5-10

${ }^{3}$ Taken from reference Board et al. 2002, Appendix A

28 months to first emplacement

5 Estimated based on similarity to Panel 3

Note that the subsurface construction schedule includes assumptions that certain preparatory work outside the GROA is performed prior to issuance of the CA, including offsite and onsite power upgrades and Balance-of-Plant (BOP) construction (Board et al. 2002, Figure 5-7).

It is possible that the first stage of the repository could be used to acquire additional engineering and scientific data. Figure 5 shows a potential configuration that could utilize a portion of Panel 1 to gather engineering and scientific data during the early phases of repository operations. The costs for the Demonstration Stage are included in the Panel 1 costs in Section 4.2.1.1.

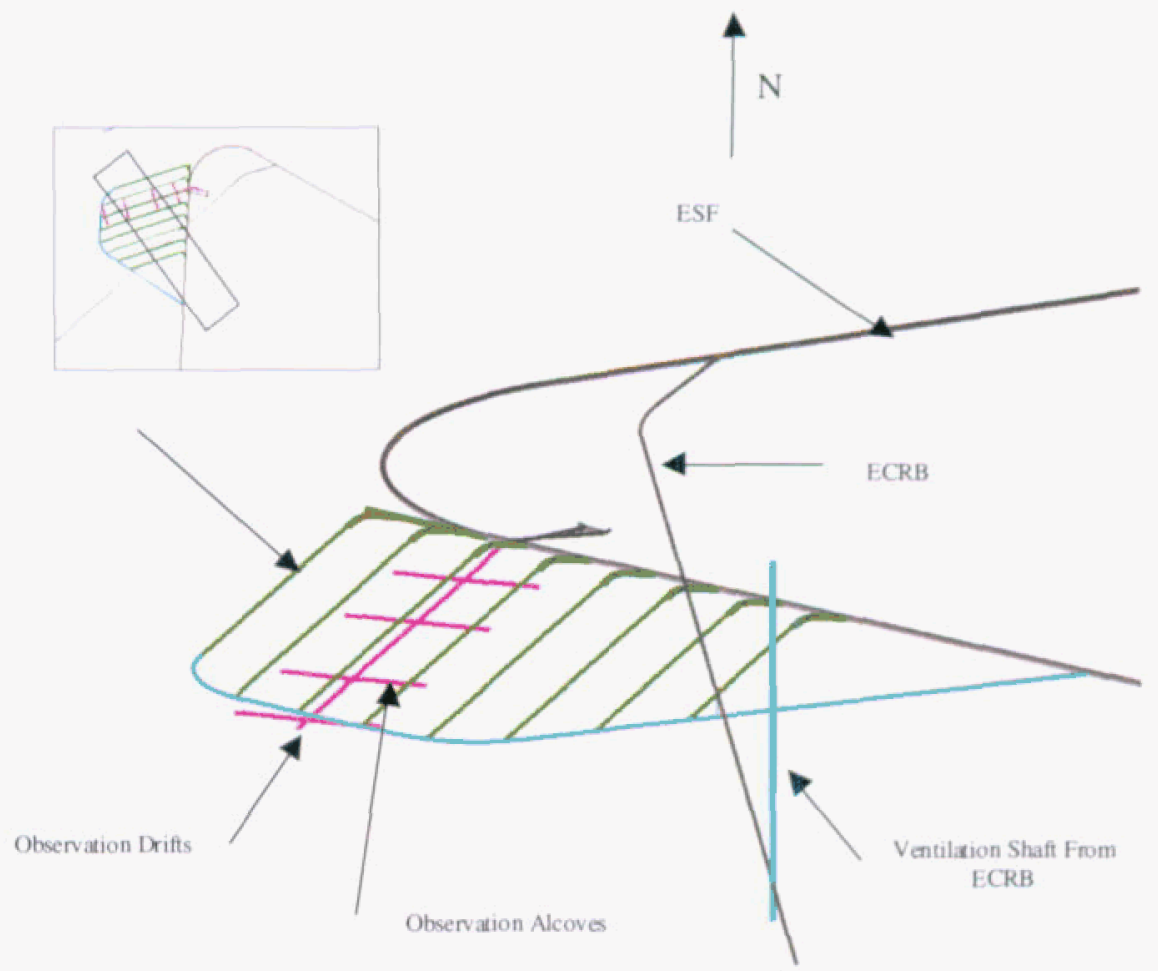

Figure 5. 3-Drift Testing Area Layout in Panel 1

\subsubsection{In-Drift Configuration}

This study (Linden 2002) examined the in-drift configuration for the emplacement drift. The present in-drift configuration consists of a circular opening configuration with an invert composed of carbon steel beams and crushed tuff ballast. The WP is carried into the drift via a rail-mounted gantry and is placed horizontally in the drift on pallets. This evaluation assessed whether the current drift geometry and emplacement drift system components (e.g., invert and emplacement pallets) should be carried forward to license application or whether the current drift geometry should be changed to better satisfy repository requirements and design constraints. 
It was recommended that the SR in-drift design configuration be carried forward with a modification to the ground support system. With this recommendation, instead of steel sets being routinely installed within the emplacement drifts, the sets would only be installed on an asneeded basis, with rock bolts and mesh providing the primary ground support function. The SR invert design configuration would be carried forward unchanged. Implementation of this recommendation would not require any changes to project requirements.

Figure 6 (Linden 2002, Figure 26) shows the recommended in-drift configuration, and Table 9 shows the estimated unit costs.

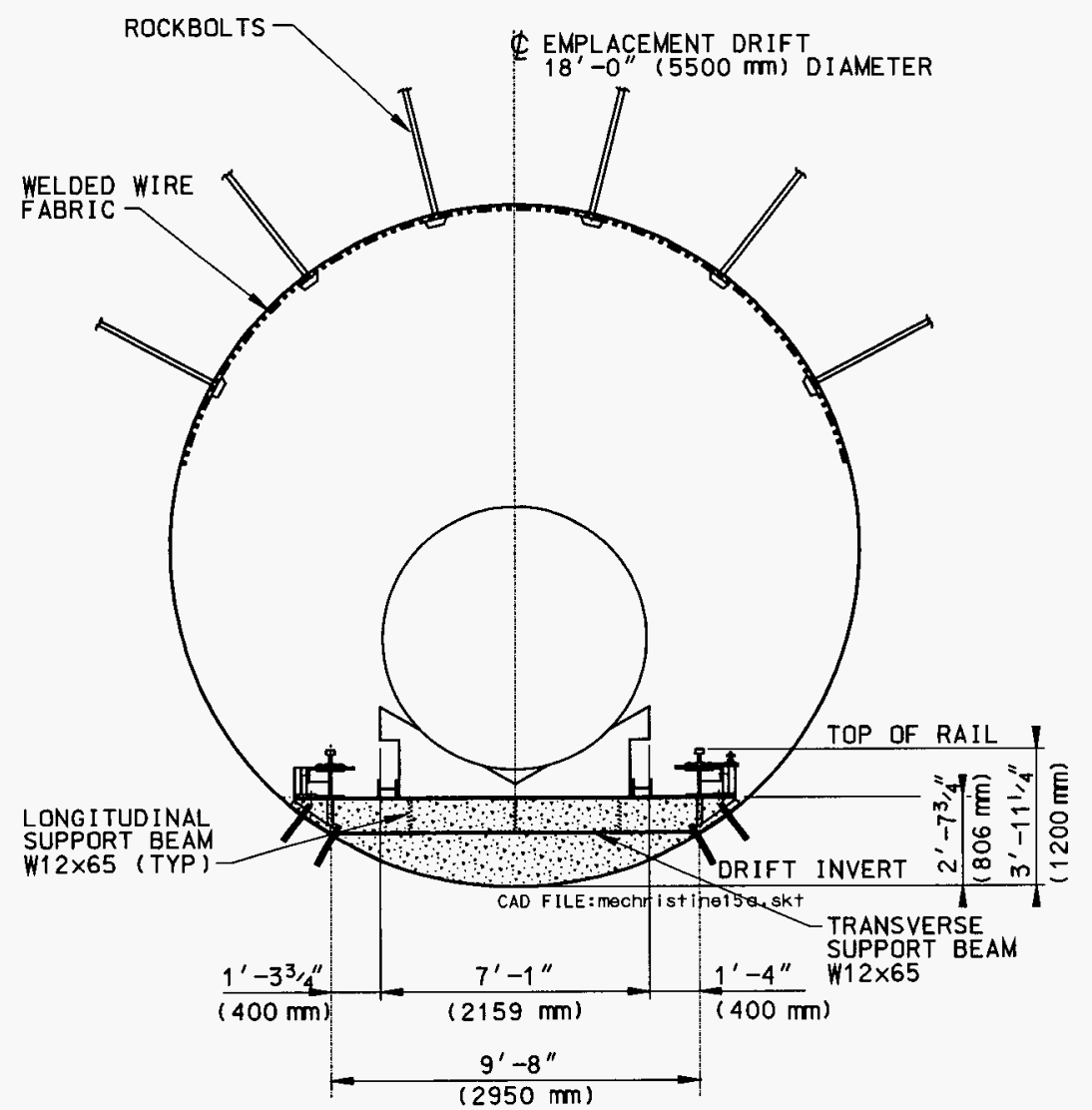

Figure 6. Recommended In-Drift Configuration

Table 9. In-Drift Design Configuration Unit Costs

\begin{tabular}{|l|c|}
\hline \multicolumn{1}{|c|}{ Item } & Unit Cost (2002\$) \\
\hline Excavation, Ground Support, and Invert & $\$ 12,357 /$ meter $^{1}$ \\
\hline WP Pallets & $\$ 57,000 /$ pallet $^{2}$ \\
\hline
\end{tabular}

1 Reference: Linden 2002: SR excavation, ground support, and invert $(\$ 14,257 / \mathrm{m})$ (Section 7.4.2.3.6.1) minus cost savings for new ground support $(\$ 1,900 / \mathrm{m})$ (Section 7.4.3.2.3.1)

2 Reference: Linden 2002, Section 7.4.2.3.6.1 


\subsubsection{Waste Package Emplacement}

This study (Silva and Stanley 2002) evaluated significant processes involving waste emplacement and retrieval, known as the Waste Emplacement/Retrieval System. This evaluation effort is a natural progression of the current baseline design for Site Recommendation, exploring fundamental emplacement and retrieval concepts against the current concept in order to refine and improve waste emplacement and retrieval.

The concept that was proposed for recommendation is an omni-directional lift transporter (OLT) for transporting the WPs from the surface Waste Handling Facilities to the subsurface emplacement drift entrance, and a rail-based gantry for handling and emplacing waste within the emplacement drifts.

Figure 7 shows a schematic of the recommended WP emplacement system. Table 10 shows the cost estimate for the OLT-gantry system, based on the 31-year emplacement period in the May 2001 TSLCC, which includes purchase of initial and replacement equipment.

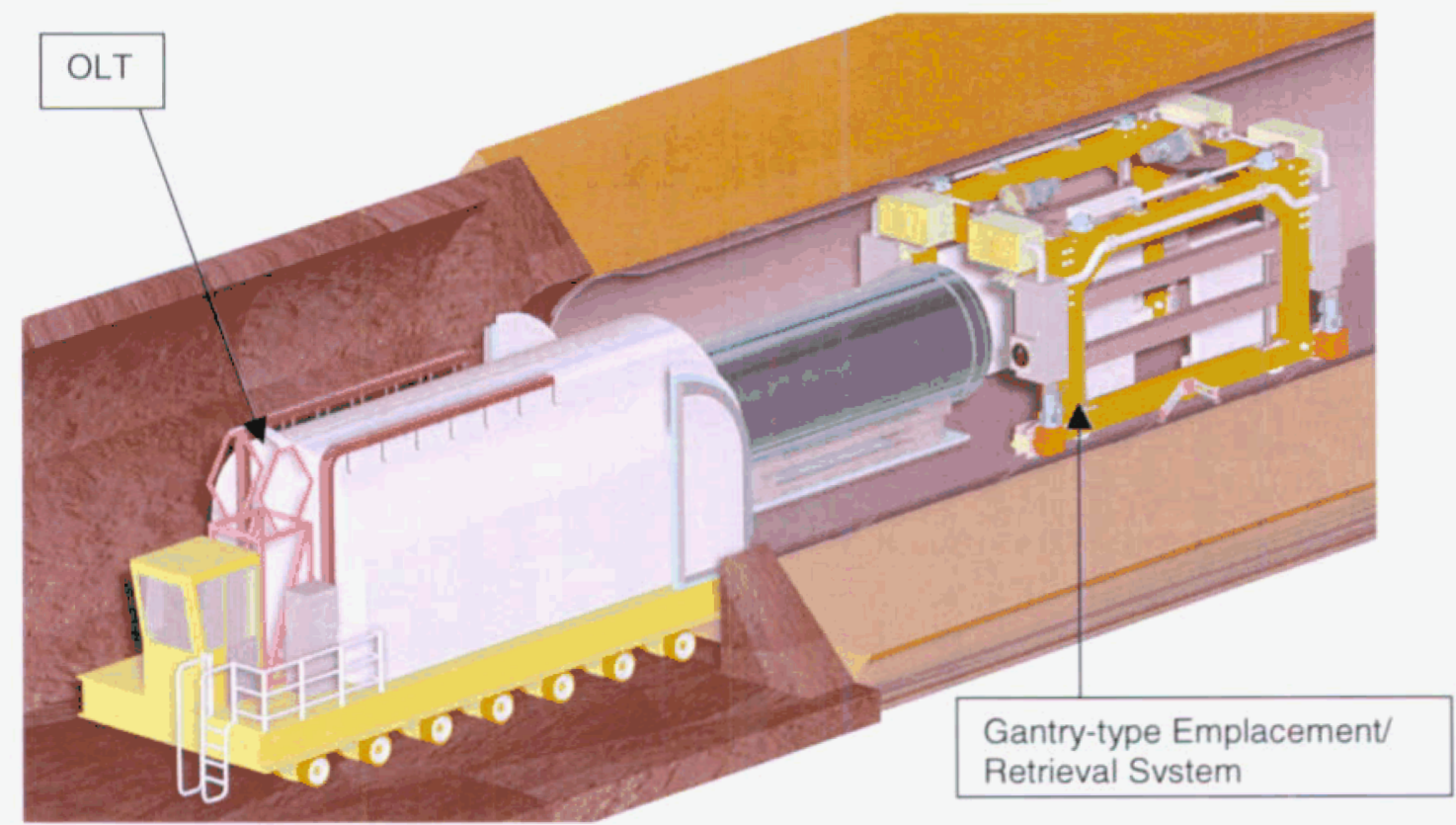

Figure 7. Recommended Waste Package Emplacement System

Table 10. Purchase Cost Summary for OLT Equipment (M 2002\$)

\begin{tabular}{|c|c|c|c|c|c|c|}
\hline & Locomotive $^{1}$ & OLT & $\begin{array}{c}\text { OLT } \\
\text { Shielding }\end{array}$ & $\begin{array}{c}\text { Emplacement } \\
\text { Gantry }\end{array}$ & $\begin{array}{c}\text { Gantry } \\
\text { Transporter }\end{array}$ & $\begin{array}{c}\text { Personnel } \\
\text { Carrier }\end{array}$ \\
\hline Initial Cost & $\$ 0.41$ & $\$ 3.13$ & $\$ 0.73$ & $\$ 1.40$ & $\$ 0.71$ & $\$ 0.32$ \\
\hline Replacement Cost & $\$ 0.34$ & $\$ 2.51$ & $\$ 0.029$ & $\$ 1.12$ & $\$ 0.57$ & $\$ 0.25$ \\
\hline
\end{tabular}

A locomotive is needed in the OLT design to transport the emplacement gantry on a gantry carrier Note: these costs were taken from Table 10 of Silva and Stanley 2002, adjusted to 2002 dollars (escalation factor of 1.044), and converted to millions 


\subsubsection{Surface Facilities}

This section summarizes the results of the repository sub-studies addressing waste handling facility (WHF) functions and layout, and storage.

\subsubsection{Waste Handling Facility}

The objective of this study (Brown 2002) was to evaluate and recommend the design and construction approach to be employed by the Yucca Mountain Project Surface Facilities responsible for receiving, processing, and packaging radioactive waste for emplacement. The current concept of constructing one large integrated Waste Handling Building was compared to a phased modular approach, with greater flexibility, improved incorporation of lessons learned, and a lower initial cost profile, but a higher total cost.

Based upon a thorough review of the options available, it was recommended for further study that the surface facilities be constructed in a phased approach consisting of multiple buildings, with the functions of the overall surface facilities distributed amongst them.

In the recommended option, fuel is handled primarily dry, with limited wet capability for offnormal fuel. This is similar to the approach used in La Hague, France. Casks and WPs are moved laterally using an OLT, both between and within buildings to reduce the number of lifts and operations.

Initial construction (Phase 1) would consist of a facility referred to as a "finishing building" (FB), equipped with a small processing line capable of processing bare fuel and canisters and finishing WPs for emplacement. This processing line allows for delayed completion of the primary processing building until after 2010, when significant quantities of material are transported to the site for processing. The processing line would continue to be used for processing bare fuel, canisters or both. Note that the waste transfer system in this building is assumed to utilize a dry transfer system (DTS) similar to the cold demonstration project system developed at INEEL (Brown 2002, Section 3.6).

After completion of the first phase of construction, a wet Waste Transfer Facility (WTF) would be constructed to support processing off-normal fuel and storing assemblies too hot for dry storage (Phase 2). In addition, several support facilities would also be constructed at this time. As proposed, the surface facilities have limited thermal blending inventory storage. This would necessitate either a substantial increase in the pool capacity or a separate aging facility to reduce the overall heat load and provide a blending inventory, and/or a change in the maximum thermal heat limits for the individual WPs.

When additional processing capacity is needed, a dry WTF with finishing capability would be constructed (Phase 3). Other support facilities would in general remain similar to the ones described in the Site Recommendation baseline. 
Figure 8 shows the locations of the recommended WHF phases. Tables 11 and 12 show the estimated costs and capacities of the WHF phases. Note that Table 11 does not include costs for the surface aging facility shown in Figure 8; these costs are discussed in Section 4.2.2.2.

Table 11. Surface Facility Construction Costs and Schedules

\begin{tabular}{|c|c|c|}
\hline Facility / Function & $\begin{array}{c}\text { Cost } \\
(\mathrm{M} 2002 \$)^{1}\end{array}$ & $\begin{array}{l}\text { Schedule } \\
\text { (Weeks) }^{1}\end{array}$ \\
\hline \multicolumn{3}{|c|}{ Phase 0 - Construction That Could be Performed Prior to Construction Authorization (CA) } \\
\hline Road from North Portal to Interface Point & $\$ 6.6$ & 24 \\
\hline Rail from North Portal to Interface Point & $\$ 6.6$ & 24 \\
\hline Fill removal & $\$ 2.6$ & 10 \\
\hline Subtotal & 15.8 & \\
\hline \multicolumn{3}{|c|}{ Phase 1 - Construction Necessary to Support Initial Operations (post-CA) } \\
\hline $\begin{array}{l}\text { Half-size FB with processing and two cask preparation } \\
\text { areas }\end{array}$ & $\$ 135.4^{2}$ & 49 \\
\hline Pit for handling WPs from Aging & $\$ 2.5$ & $O$ (part of FB) \\
\hline Cask carrier preparation building with lift beams & $\$ 30.8$ & 24 \\
\hline OLTs for shipping casks (2) & $\$ 2.0$ & N/A \\
\hline OLTs with integral shielding within welding area (2) & $\$ 4.0$ & N/A \\
\hline Fill emplacement & $\$ 4.1$ & 5 \\
\hline Subtotal & $\$ 178.8$ & \\
\hline \multicolumn{3}{|c|}{ Phase 2 - Construction Necessary to Support Long-Term Operations } \\
\hline Rail staging & $\$ 4.4^{2}$ & 12 \\
\hline $\begin{array}{l}\text { Complete equipment in cask carrier preparation } \\
\text { building }\end{array}$ & $\$ 10.3^{2}$ & 12 \\
\hline Wet WTF without load-out capability & $\$ 115.4$ & 53 \\
\hline Waste treatment building (WTB) & $\$ 21.0$ & 45 \\
\hline Empty DC Preparation building & $\$ 17.3$ & 24 \\
\hline OLTs for shipping casks (2) & $\$ 2.0$ & N/A \\
\hline OLTs with integral shielding within welding area (2) & $\$ 4.0$ & N/A \\
\hline Subtotal & $\$ 174.4$ & \\
\hline \multicolumn{3}{|c|}{ Phase 3 - Construction Necessary to Support Full Scale Operations } \\
\hline Dry WTF with half-size finishing building Incorporated & $\$ 201.1$ & 68 \\
\hline OLTs for shipping casks (4) & $\$ 4.0$ & N/A \\
\hline $\begin{array}{l}\text { OLTs with integral shielding for transfer between } \\
\text { WTFs and within welding areas (4) }\end{array}$ & $\$ 8.0$ & N/A \\
\hline $\begin{array}{l}\text { Shielded above grade corridor between dry WTF and } \\
\text { finishing building with processing ( } 100 \text { feet) }\end{array}$ & $\$ 2.4$ & 8 \\
\hline Subtotal & $\$ 215.5$ & \\
\hline Total & $\$ 593.5$ & \\
\hline
\end{tabular}


1 Reference: Brown 2002, Tables 4-1 through 4-4

2 Costs adjusted from values in Waste Handling Facility Report as a result of review by Cost Estimating Group

Table 12. Surface Facility Modular Capabilities

\begin{tabular}{|c|c|c|}
\hline Phase & $\begin{array}{c}\text { Cumulative Throughput } \\
\text { (Casks/year) }\end{array}$ & $\begin{array}{c}\text { Cumulative Nominal CSNF } \\
\text { Capacity (MTHM/year) }\end{array}$ \\
\hline 1 & 365 & $\begin{array}{c}\sim 400 \text { (truck only) } \\
\sim 1,800 \text { (mostly rail) }\end{array}$ \\
\hline 2 & 365 & $\begin{array}{c}\sim 400 \text { (truck only) } \\
\sim 1,800 \text { (mostly rail) }\end{array}$ \\
\hline 3 & 1,100 & $\sim 4,000$ \\
\hline
\end{tabular}

1 Reference: Brown 2002,Table 3-4 (Option 1)

2 Estimated from shipment calculations for Transportation scenarios 1B and 7A (see Table 4); includes proportional amount of defense wastes

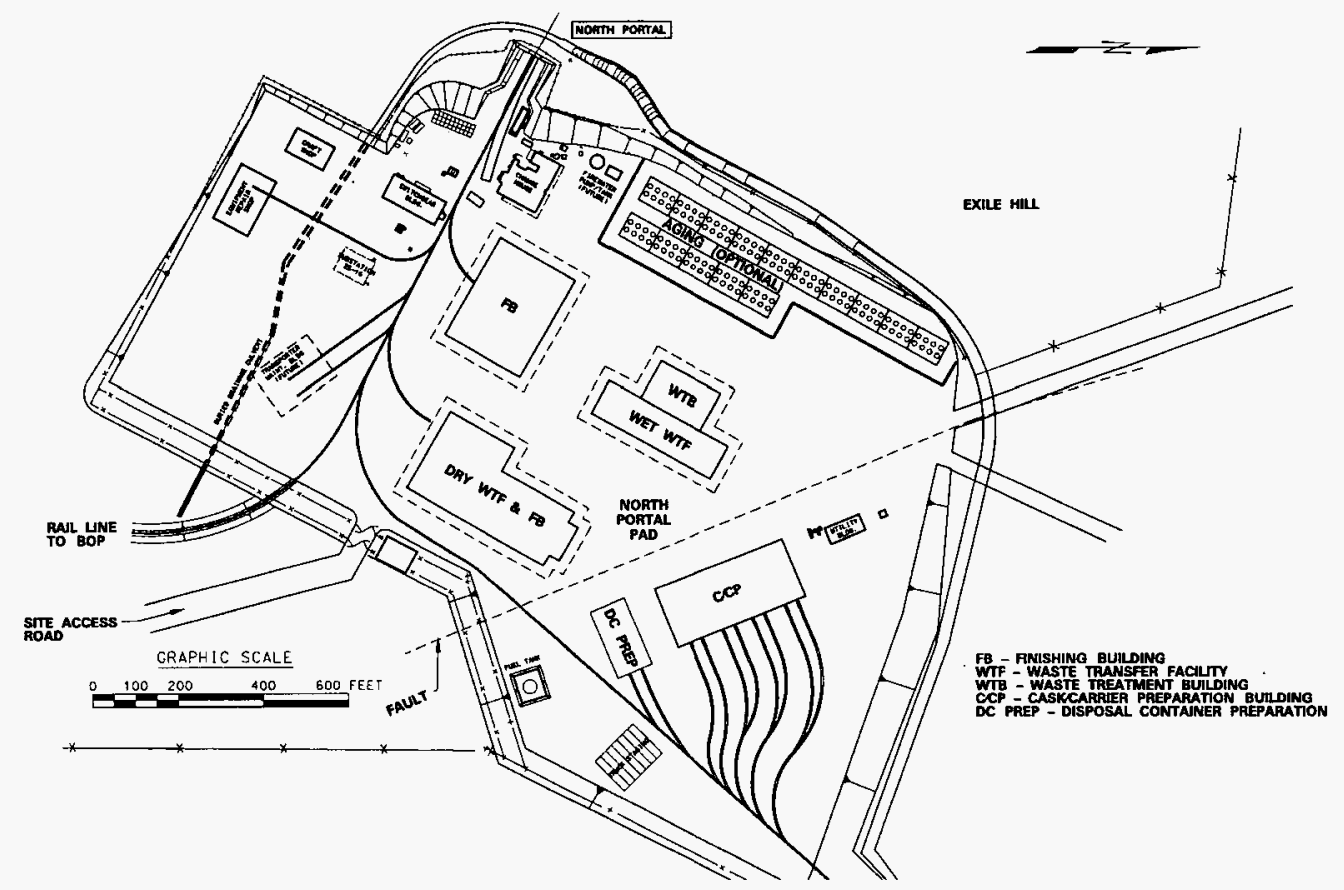

Figure 8. Modular Surface Facilities Layout

\subsubsection{Aging}

The purpose of this study (McDaniel 2002) was to identify options and issues for aging commercial spent nuclear fuel received for disposal at the Yucca Mountain Monitored Geologic Repository. Some early shipments of commercial spent nuclear fuel to the repository may be received with high-heat-output (younger) fuel assemblies that will need to be managed to meet thermal goals for emplacement. The capability to age as much as 40,000 metric tons of heavy metal of commercial spent nuclear fuel would provide more flexibility in the design to manage this younger fuel and to de-couple waste receipt and waste emplacement. 


\section{A. Storage Locations}

The following storage locations were evaluated:

- Surface storage at four locations near the North Portal

- Subsurface storage in the permanent emplacement drifts and in a new subsurface area

For the purposes of this study, only surface storage locations were considered.

The surface storage sites were chosen based on relatively flat sites located close to the North Portal WHF (see Figure 9). Three sites were identified: north of Exile Hill, Midway Valley, and south along Exile Hill. A fourth storage site in the North Portal Pad area was also included.

The concrete storage pads were sized considering current commercial vendor designs for five different dry storage cask systems and one vertical WP-storage configuration. The storage pads were sized for 5,000 MTHM of storage; this results in 504 storage casks on a $665 \mathrm{ft}$ by $609 \mathrm{ft}$ pad.

The study evaluated storage sites for up to 20,000 MTHM in 5,000 MTHM modules. The Exile Hill and Midway Valley sites could accommodate 20,000 MTHM. The North Portal site is only large enough for 5,000 MTHM. The North Portal Pad site could accommodate about 1,000 MTHM. There is a possibility that as much as 40,000 MTHM of storage may be needed. Further evaluations would be required to determine if the Exile Hill and Midway Valley sites could be expanded beyond 20,000 MTHM of storage.

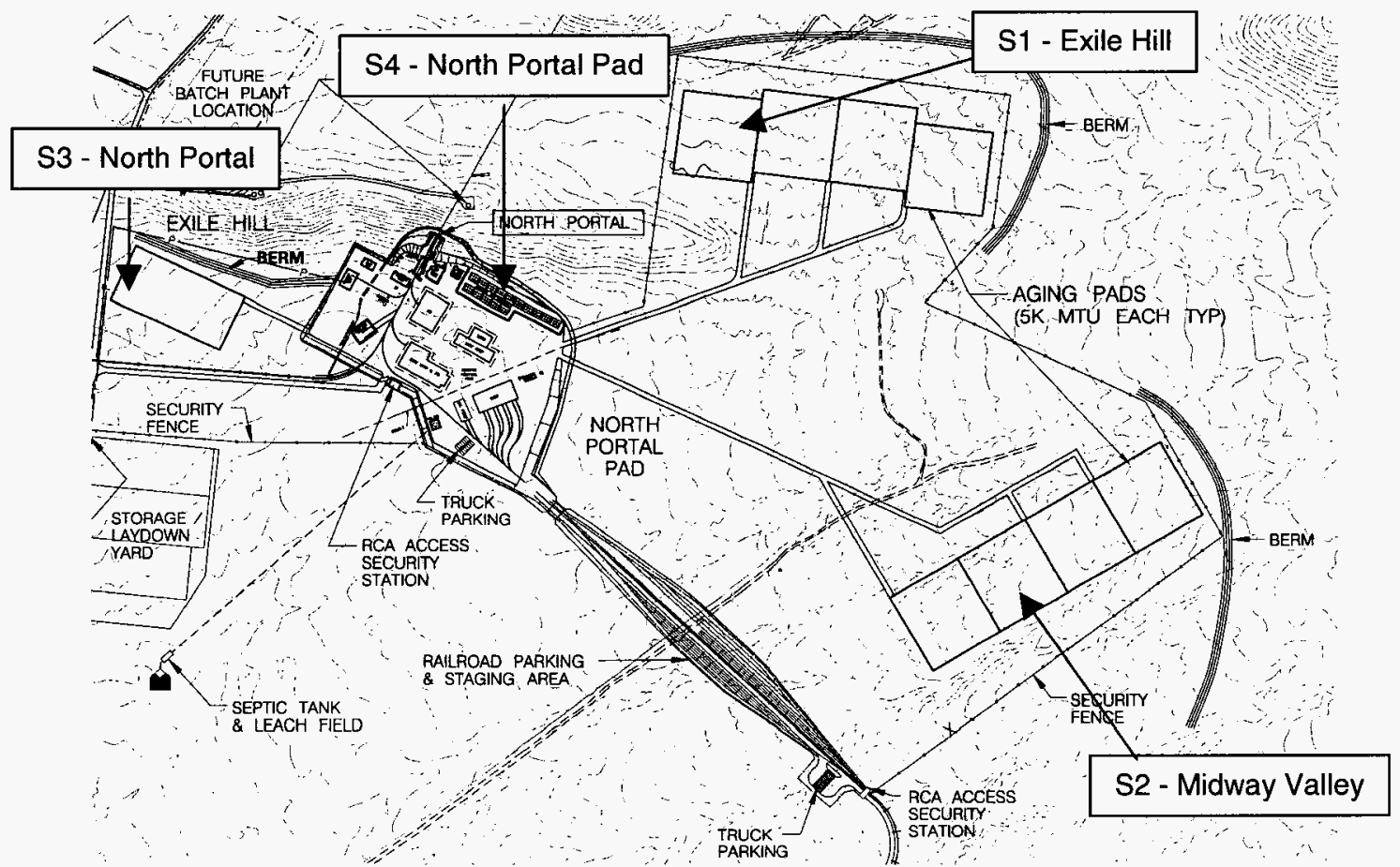

Figure 9. Potential Surface Aging Locations 


\section{B. Storage Containers}

The following containers for surface storage were evaluated and recommended:

- Dual Purpose Canisters (DPC) - DPCs received at the repository are placed in a storage cask for aging; additionally, uncanistered CSNF could be loaded into a new DPC at the repository for aging.

- Multi-Purpose Canisters (MPC) - MPCs received at the repository are placed in a storage cask for aging, similar to DPCs, but can also be used for disposal using a disposal overpack.

- New disposal canister for uncanistered CSNF - uncanistered CSNF would be placed in a new "storage and disposal" canister for aging; the canister would also be used for disposal.

\section{Cost Information}

Pricing information for the spent fuel storage equipment was provided by system vendors, fabricators of canisters and casks, and experienced industry consultants. The unit costs shown in Table 13 represent the additional capital costs for the storage container options.

Table 13. Unit Costs for Storage Containers (M 2002\$)

\begin{tabular}{|l|c|c|c|c|}
\hline \multicolumn{1}{|c|}{ Option } & $\begin{array}{c}\text { Canister/Basket, } \\
\text { 10 MTHM }\end{array}$ & $\begin{array}{c}\text { Storage Cask, } \\
\text { 10 MTHM }\end{array}$ & $\begin{array}{c}\text { Carrier/Equip, } \\
\text { 20,000 MTHM }\end{array}$ & $\begin{array}{c}\text { Unit Capital } \\
\text { Cost for } \\
\text { Container } \\
\text { Surface Aging } \\
\text { 1 MTHM }\end{array}$ \\
\hline $\begin{array}{l}\text { C1 - DPC } \\
\text { Vertical }\end{array}$ & 0 & 0.250 & 4.0 & 0.0252 \\
\hline $\begin{array}{l}\text { C1 - DPC } \\
\text { Horizontal }\end{array}$ & 0 & 0.150 & 12.8 & 0.0156 \\
\hline $\begin{array}{l}\text { C2-MPC } \\
\text { Vertical }\end{array}$ & 0 & 0.250 & 4.0 & 0.0252 \\
\hline $\begin{array}{l}\text { C2-MPC } \\
\text { Horizontal }\end{array}$ & 0 & 0.150 & 12.8 & 0.0156 \\
\hline $\begin{array}{l}\text { C3- Disposal } \\
\text { Canister } \\
\text { Vertical }\end{array}$ & 0.450 & 0.250 & 4.0 & 0.0702 \\
\hline $\begin{array}{l}\text { C3 - Disposal } \\
\text { Canister } \\
\text { Horizontal }\end{array}$ & 0.400 & 0.150 & 12.8 & 0.0556 \\
\hline
\end{tabular}

Note: Data taken from McDaniel 2002, Table 2.

Costs were developed for surface storage by estimating material quantities and associated direct costs and field distributable costs. Table 14 lists the resulting unit capital costs for the 4 surface storage locations. 
Table 14. Unit Costs for Surface Storage

\begin{tabular}{|l|c|c|}
\hline \multicolumn{1}{|c|}{ Option } & $\begin{array}{c}\text { Direct Cost } \\
\text { (M 2002\$) }\end{array}$ & $\begin{array}{c}\text { Unit Direct Cost } \\
\text { SM per MTHM }\end{array}$ \\
\hline S1 - Exile Hill: 5000 MTHM & 22.1 & 0.0044 \\
\hline S1 - Exile Hill: 20,000 MTHM & 86.3 & 0.0043 \\
\hline S2 - Midway Valley: 5,000 MTHM & 22.5 & 0.0045 \\
\hline S2 - Midway Valley: 20,000 MTHM & 86.8 & 0.0043 \\
\hline S3 - North Portal: 5000 MTHM & 21.6 & 0.0043 \\
\hline S4 - North Portal Pad: 1000 MTHM & 7.7 & 0.0075 \\
\hline
\end{tabular}

Note: Data taken from McDaniel 2002, Table 3

\section{Unit Cost Assumptions for System Evaluation}

The aging study did not recommend a single storage cask design or location. For the purpose of this study, the following cost assumptions were made for aging:

- Commercial DPCs will be used for CSNF aging. This option was selected because of the current lack of licensed commercial MPC designs, and the uncertainties associated with development of a storage and disposal canister for the repository. The cost for storage casks (for CSNF received in DPCs) is assumed to be the average cost of the C1 (vertical) and $\mathrm{C} 2$ (horizontal) option storage casks $(\$ 0.2 \mathrm{M} /$ cask). This reflects the uncertainty as to the storage method that will ultimately be chosen. For CSNF received uncanistered, the average cost of the canister from option $\mathrm{C} 3(\$ 0.425 \mathrm{M})$ is added to the storage cask cost.

- Storage pads for surface aging are assumed to be constructed in increments as needed. The first storage pad (the North Portal Pad) is assumed to hold 1,000 MTHM; subsequent pads are constructed in 5,000 MTHM increments. The unit cost of the first storage pad is assumed to be $\$ .0075 \mathrm{M} / \mathrm{MTHM}$, and the unit cost of subsequent storage pads is assumed to be the 5,000 MTHM value for the Exile Hill/Midway Valley storage areas $(\$ 0.0045 \mathrm{M} / \mathrm{MTHM})$.

- The aging study did not include storage of defense wastes. If surface storage of defense wastes is required, it is assumed that storage canisters and casks will be developed for WP-sized quantities of defense wastes at a cost similar to those for CSNF. However, it must be noted that no designs currently exist for such storage systems. Naval SNF is assumed to require only a storage cask (similar to a DPC), whereas HLW and DSNF will require a storage system with both an internal basket and a cask (similar to uncanistered CSNF). Unit costs were assumed to be the same as for CSNF systems for "WP - sized" storage containers. 
INTENTIONALLY LEFT BLANK 


\section{SYSTEM DESIGN IMPLEMENTATION SCENARIOS}

This section describes the process for combining the results of the Repository Design Evolution Study with the results of the national and Nevada transportation options studies to produce a series of system design implementation scenarios for further evaluation.

\subsection{RECEIPT AND EMPLACEMENT SCENARIOS}

This section describes the receipt and emplacement scenarios that will be used to perform the system design implementation evaluations. For all scenarios, the last year of emplacement is assumed to be 2038, which is driven by the receipt rate of defense wastes described in Section 4.1.1. The end of closure is assumed to be 2119 , which is consistent with the 100 -year preclosure period assumed in the May 2001 TSLCC (DOE 2001e). The nominal receipt, storage, and emplacement rates for the scenarios are given in Appendix C.

\subsubsection{Scenario 1 - Mostly Rail, Reference Receipt Rates}

This scenario assumes that wastes are transported to the repository in accordance with the target schedule in the CRD (DOE 2001a, Table 1). CSNF selection for transport at utility sites is in accordance with the "youngest fuel first greater than 10 years old" (YFF10) criterion (see Appendix A for definition). Transportation is "mostly rail" (i.e., rail with LWT transport only for sites that cannot handle a rail cask). Waste is emplaced as received, with no storage. Emplacement occurs first in the subsurface Panel 1, followed immediately by emplacement in Panel 2 and subsequent panels as needed. Surface facility phases are constructed as needed to meet the receipt rate.

\subsubsection{Scenario 2 - Mostly Rail, Initial APR/ACR Receipt Rate}

This scenario assumes the same transportation modes as Scenario 1. The CSNF receipt rate is capped at the maximum rate shown in the Acceptance Priority Ranking/Acceptance Capacity Report (APR/ACR) (DOE 1995a) for 10 years (until 2019). Beginning in 2020, the CSNF receipt rate ramps up to 3,600 MTHM/year to allow the receipt schedule to catch up to the CRD target schedule. Emplacement occurs first in the subsurface Panel 1, followed immediately by emplacement in Panel 2 and subsequent panels, which are constructed as needed. Surface facility phases are constructed as needed to meet the receipt rate.

\subsubsection{Scenario 3 - Mostly Rail, Reference Receipt Rate, Delayed Emplacement}

This scenario is similar to Scenario 1, except that after the testing area in Panel 1 is filled (approximately 1,200 MTHM of CSNF and a proportional amount of defense wastes), no more waste is emplaced until 2020. This simulates a postulated requirement to perform testing on the waste emplaced in the testing area prior to proceeding with further emplacement. During this time (2013-2019), all of the waste received is assumed to be stored on the surface. In addition, construction of subsurface Panels 2 - 4 is delayed by 8 years, since Panel 2 is not needed for 
emplacement until 2020. In 2020, waste emplacement resumes at a CSNF rate of 3,600 MTHM/year (and a corresponding defense rate) in order to achieve a last year of emplacement of 2038 .

\subsubsection{Scenario 4 - Mostly Rail, Accelerated Receipt and Emplacement Rate}

This scenario is similar to Scenario 1, but assumes that the CSNF waste receipt and emplacement rates are increased by $1 / 3$ to a maximum of 4,000 MTHM/year. Emplacement occurs first in the subsurface Panel 1, followed immediately by emplacement in Panel 2 and subsequent panels, which are constructed as needed. Surface facility phases are constructed as needed to meet the receipt rate.

\subsubsection{Scenario 5 - Initial Truck/Heavy Haul, Low Rate}

This scenario assumes that the Nevada rail line will not be available until 2015; therefore, transportation to the repository during the first 5 years of operation will be by Legal Weight Truck (LWT) and limited heavy haul (for naval SNF only). The initial CSNF transportation rate is limited to $100 \mathrm{MT} /$ year and the HLW transportation rate is limited to $10 \mathrm{MTHM} / \mathrm{year}$. Naval SNF is assumed to be shipped by heavy haul until 2015. The CSNF receipt rate ramps up to 3,600 MTHM/year after 2014, to allow the receipt to catch up with the CRD target schedule. The defense wastes receipt rates also ramp up to the reference rate after 2014. Emplacement occurs first in the subsurface Panel 1, followed immediately by emplacement in Panel 2 and subsequent panels, which are constructed as needed. Construction of Panels 2-4 is delayed by 3 years relative to the reference case. Surface facility phases are constructed as needed to meet the receipt rate.

\subsubsection{Scenario 6 - Initial Truck/Heavy Haul, High Rate}

This scenario is similar to Scenario 5, except that the initial (2010-2014) receipt rates for CSNF and defense wastes (except naval SNF) are increased by a factor of four.

\subsubsection{Scenario 7: Initial Truck/Heavy Haul, High Rate, 2 Year Rail Delay}

This scenario is similar to Scenario 6, but assumes that the Nevada rail line will become operational in 2012, instead of 2015.

Tables 15 and 16 summarize the characteristics of these scenarios. 


\begin{tabular}{|c|c|c|c|c|c|c|c|}
\hline 岂总兽 & $\frac{0}{\frac{0}{4}}$ & $\frac{0}{\frac{1}{4}}$ & $\frac{0}{\frac{1}{4}}$ & $\frac{0}{\frac{1}{4}}$ & $\frac{0}{\frac{0}{4}}$ & $\frac{0}{\frac{1}{4}}$ & $\stackrel{\frac{0}{4}}{\frac{1}{1}}$ \\
\hline 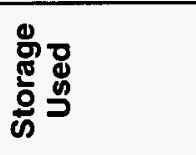 & 운 & 운 & 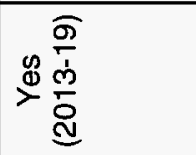 & i & 은 & 운 & 온 \\
\hline 峞悹 & 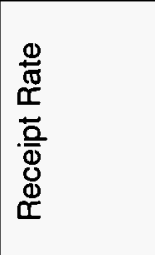 & 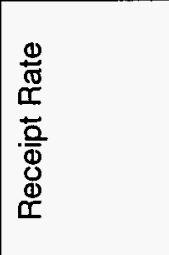 & 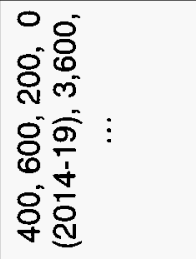 & 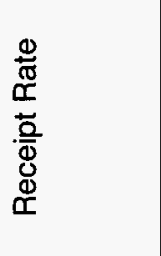 & 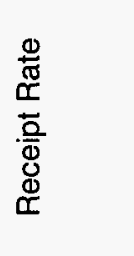 & 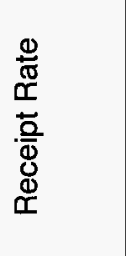 & 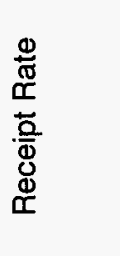 \\
\hline & 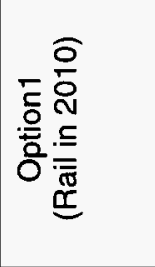 & 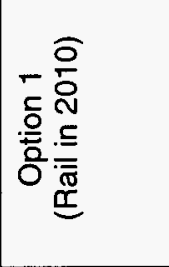 & 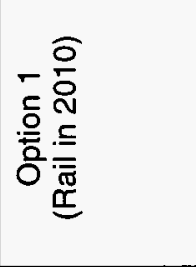 & 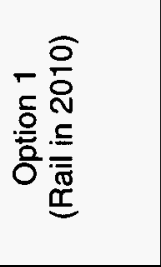 & 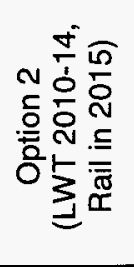 & 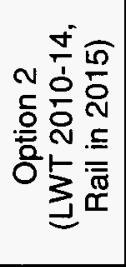 & 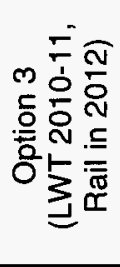 \\
\hline 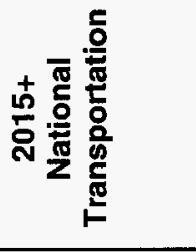 & 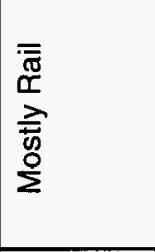 & 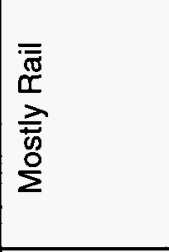 & 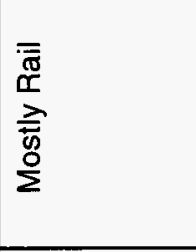 & 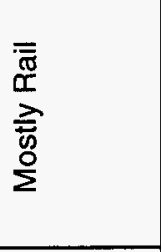 & 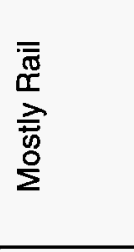 & 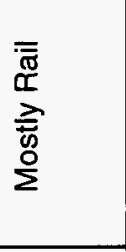 & 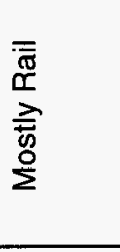 \\
\hline 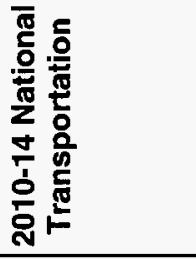 & 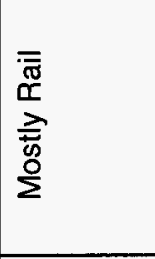 & 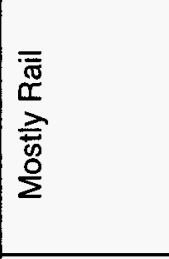 & 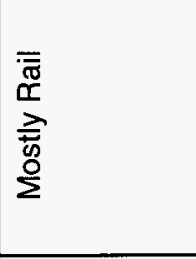 & 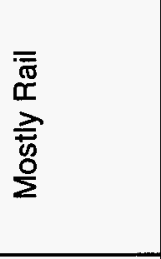 & 歺 & $\xi$ & 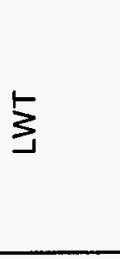 \\
\hline 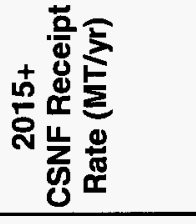 & 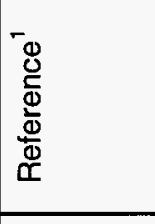 & 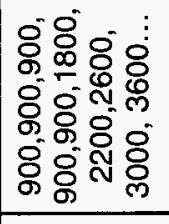 & 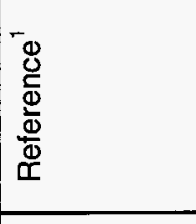 & 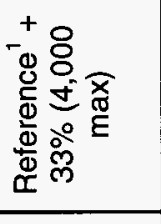 & 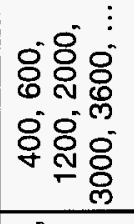 & 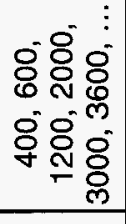 & 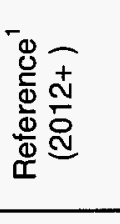 \\
\hline 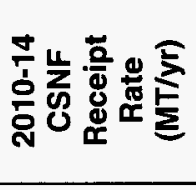 & 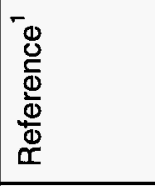 & $\begin{array}{l}80 \\
88.8 \\
8 \dot{8} \\
\dot{y} 8\end{array}$ & 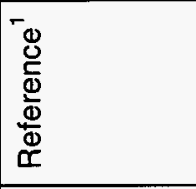 & 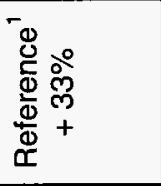 & $\begin{array}{l}80 \\
80 \\
80 \\
08 \\
0\end{array}$ & 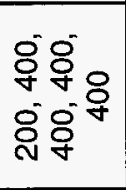 & 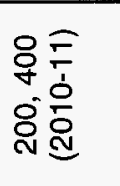 \\
\hline 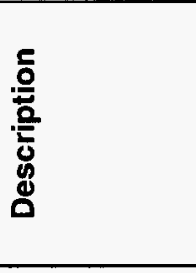 & 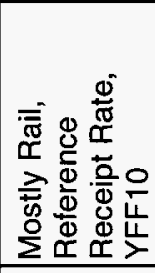 & 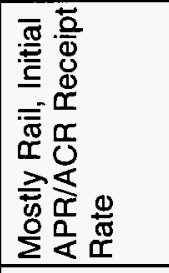 & 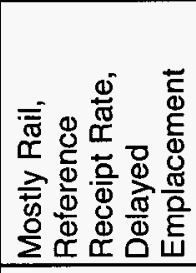 & 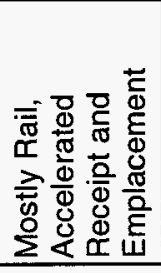 & 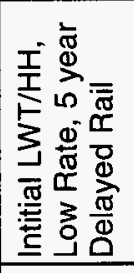 & 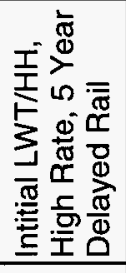 & 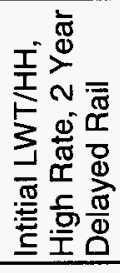 \\
\hline $\begin{array}{l}\text { 은 } \\
\text { 응 } \\
\text { 융 }\end{array}$ & - & $\sim$ & $m$ & $\nabla$ & in & 0 & $r$ \\
\hline
\end{tabular}




\begin{tabular}{|c|c|c|c|c|c|c|c|}
\hline 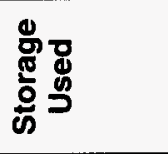 & $\frac{0}{2}$ & 은 & 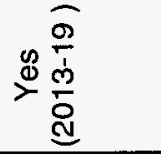 & 운 & 을 & 은 & z \\
\hline 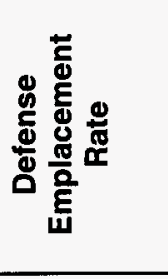 & 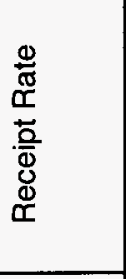 & 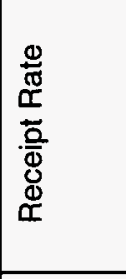 & 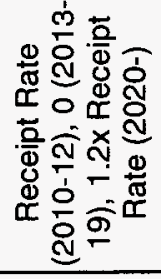 & 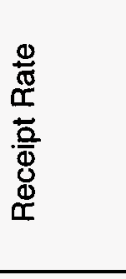 & 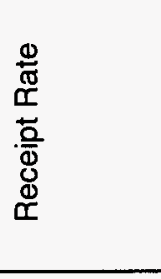 & 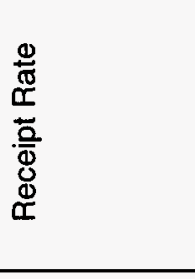 & 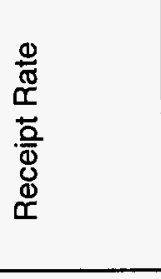 \\
\hline 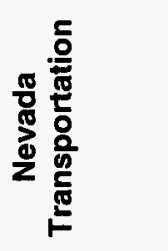 & 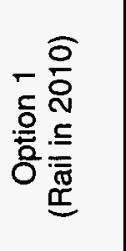 & 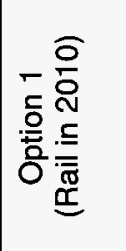 & 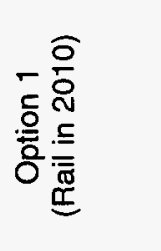 & 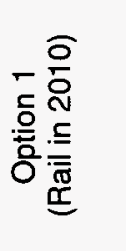 & 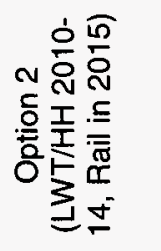 & 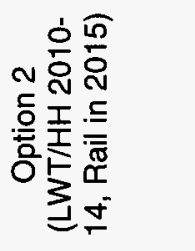 & 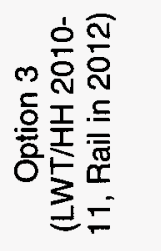 \\
\hline 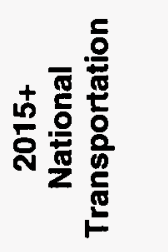 & $\begin{array}{l}\overline{\overline{\widetilde{\pi}}} \\
\text { व }\end{array}$ & 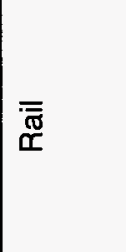 & $\overline{\overline{\mathbb{\sigma}}}$ & $\begin{array}{l}\overline{\overline{\widetilde{\sigma}}} \\
\widetilde{\widetilde{d}}\end{array}$ & $\begin{array}{l}\overline{\overline{\mathbb{\pi}}} \\
\tilde{\check{I}}\end{array}$ & $\begin{array}{l}\overline{\overline{\mathbb{\pi}}} \\
\widetilde{\widetilde{N}}\end{array}$ & $\begin{array}{l}\overline{\overline{\widetilde{\pi}}} \\
\tilde{\check{\nu}}\end{array}$ \\
\hline 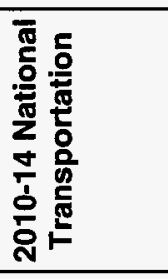 & $\begin{array}{l}\overline{\bar{\sigma}} \\
\bar{\alpha}\end{array}$ & \begin{tabular}{|l}
$\overline{\overline{\widetilde{\pi}}}$ \\
$\overline{\check{\gamma}}$
\end{tabular} & \begin{tabular}{|l}
$\overline{\overline{\widetilde{\pi}}}$ \\
\end{tabular} & $\begin{array}{l}\overline{\overline{\widetilde{\pi}}} \\
\overline{\widetilde{I}}\end{array}$ & 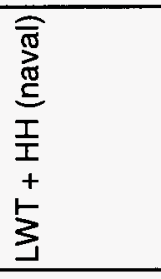 & 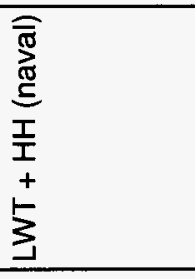 & 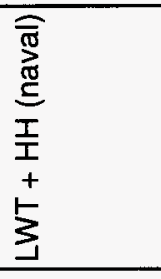 \\
\hline 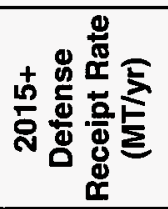 & 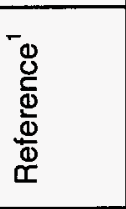 & 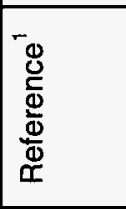 & 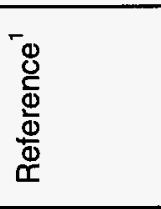 & 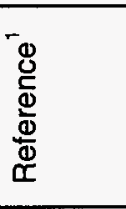 & 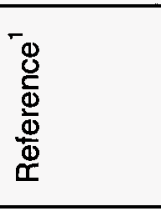 & 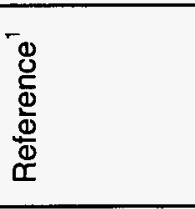 & 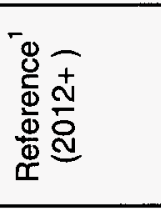 \\
\hline 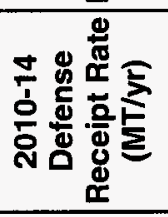 & 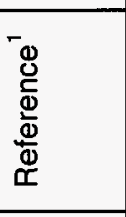 & 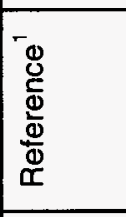 & 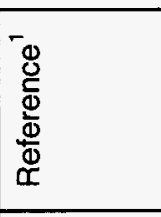 & 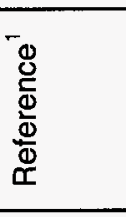 & 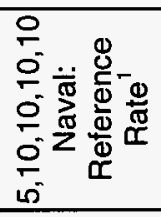 & 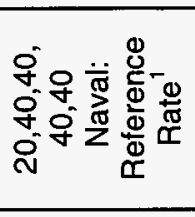 & 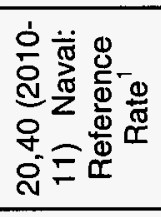 \\
\hline 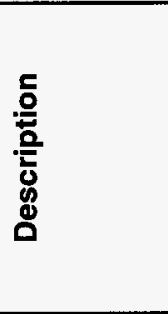 & 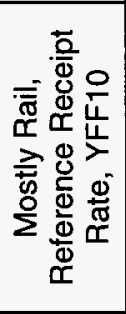 & 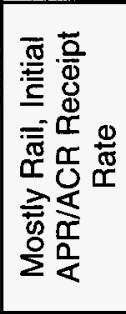 & 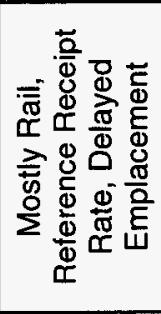 & 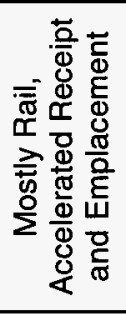 & 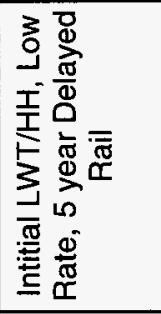 & 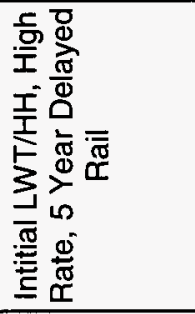 & 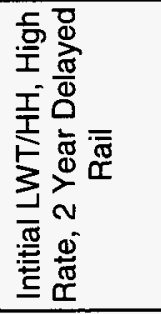 \\
\hline 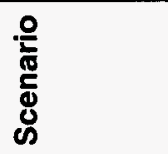 & - & $\sim$ & $m$ & $\nabla$ & o & $\omega$ & $\wedge$ \\
\hline
\end{tabular}




\subsection{REPOSITORY DESIGN MODULE TIME-PHASING}

For each of the receipt and emplacement scenarios described in Section 5.1, the construction and operation of the modular components of the repository surface facilities described in Section 4 were time-phased to match the receipt, aging, and emplacement rates. This was accomplished by matching the capabilities of the modular components to the annual receipt rates.

\subsubsection{Surface Facilities}

The Surface Facilities include five elements:

- Phase 0 (Permanent Plant Facilities)

- Phase 1

- Phase 2

- Phase 3

- Balance of Plant \& Construction Support

Phase 0 (Permanent Plant Facilities) includes in-plant road, rail \& fill removal at the North Portal. The schedule for Phase 0 is the same for all 7 scenarios.

Phase 1 includes North Portal fill, half size finishing building, Cask Carrier Prep Building, and Omni-Directional Lift Transporters. The schedule for Phase 1 is the same for all scenarios. The cost of the following items is excluded from Phase 1: Operator Recruitment \& Training; Operating Manuals/Procedures; Operations Readiness Review; and Hot Start-up Testing. It is assumed these costs are picked up elsewhere. These costs are included in O\&M costs. Phase 1 is also assumed to include a 1,000 MTHM surface aging facility at the North Portal Pad location (see Figure 9, location S4) for all scenarios.

Phase 2 includes Waste Transfer Facility (wet), Complete Rail Siding, Waste Treatment Building, Empty DC Prep Building, Complete Cask Carrier Prep, and OLTs. The cost of the following items is excluded from Phase 2: Operator Recruitment and Training; Operating Manuals/Procedures; Operations Readiness Review; and Hot Start-up Testing. These costs are included in O\&M costs.

Phase 3 includes Dry Waste Transfer Facility, Transfer Corridor, and OLTs. The timing for Phase 3 construction changes such that the facilities are completed prior to the year the waste receipt rate exceeds 365 transportation casks per year. The cost of the following items is excluded from Phase 3: Operator Recruitment and Training; Operating Manuals/Procedures; Operations Readiness Review; Hot Start-up Testing. These costs are included in O\&M costs.

Balance of Plant \& Construction Support includes all other Surface Facilities included in the May 2001 TSLCC except those facilities identified in Phases 1-3 above. The schedule for these surface facilities is the same for all 7 scenarios. Construction Support ( $\$ 82.5$ million) is accelerated to pre-CA time frame, commencing in FY2006. The schedule for pre-CA Construction Support is the same for all 7 scenarios. 
The total CSNF blending storage capacity in the three surface facilities phases consists of 10 canisters plus 144 PWR (or $324 \mathrm{BWR}$ ) assemblies in the Phase 3 dry WTF, and 480 PWR (or 1080 BWR) assemblies in the Phase 2 wet WTF (Brown 2002, Sections 3.7.1 and 3.7.2), for a total of approximately 400 MTHM. This is substantially less than the 5,000 MTHM capacity of the blending pool in the SR design. The significant reduction of storage capacity will necessitate either a separate aging facility to reduce overall heat load and provide a blending inventory and/or a change in the thermal heat limits for the individual WPs. A thermal operating strategy for the repository is currently under development. Once this is completed, a detailed analysis should be performed during preliminary design to determine the appropriate amount and type of WHF blending storage. For the purposes of this study, it was assumed that the 1,000 MTHM North Portal Pad aging area described in Section 4.2.2 is also used for WP blending purposes, giving a total blending storage capacity of about 1,400 MTHM. It was assumed that this blending capacity would be sufficient to support a HTOM. The cost of the North Portal Pad aging area was added to Phase 1 for all scenarios, plus 100 storage casks/canisters (about 1,000 MTHM) for all scenarios except Scenario 3 (which already includes significant storage).

The details of the surface facilities phased construction schedule and associated annual costs are contained in an Excel worksheet included in Appendix D.

It should be noted that the preliminary construction schedules developed for the surface facilities in the Design Evolution Study result in an initial operations date of December 2010. While this meets the goal of 2010 initial operation, it does not allow for receipt and processing of a significant quantity of waste in calendar year 2010 (certainly not approaching the CRD target level of 400 MTHM CSNF).

\subsubsection{Subsurface Facility}

Subsurface facilities include Panels 1-4, South Portal in Panel 1, the new portal in Panel 2, and associated facilities. The schedule for all scenarios except Scenarios 3 and 5 is driven by the estimated advance rate of the tunneling operation, not the waste emplacement rate; the Scenario 3 schedule for Panels $2-4$ is delayed 8 years to reflect the moratorium on subsurface construction following filling of the initial subsurface test area, and the Scenario 5 schedule is delayed 3 years in response to the low initial waste receipt rate. The details of the subsurface phased construction schedule and associated annual costs are contained in an Excel worksheet included in Appendix D.

The preliminary construction schedules developed for the subsurface Panel 1 in the Design Evolution Study result in an initial operations date of December 2010. While this meets the goal of 2010 initial operation, it does not allow for emplacement of a significant quantity of waste in calendar year 2010 (certainly not approaching the CRD target level of 400 MTHM CSNF). However, this schedule was based on completion of 5 of the 8 drifts in Panel 1 by the end of 2010. The detailed construction schedule for Panel 1 (Board et al. 2002, Figure 5-8) shows that the first 3 drifts (which have about a 1,200 MTHM capacity), are completed by about June 2010 . Even allowing time for a readiness review, it is possible that sufficient emplacement drifts for 400 MTHM could be available in 2010. 
Table 17 summarizes the operation dates of the surface and subsurface modules for the 7 receipt and emplacement scenarios. Note that in some scenarios (e.g., 1, 3, 4, and 6), Phase 3 of the surface facilities is required to commence operation at the same time as Phase 2 . This reflects the need for the additional processing capability in Phase 3 (note that Phase 2 does not include any cask processing capability, but is required for operation of Phase 3 ).

Table 17. Surface and Subsurface Modules Development

\begin{tabular}{|l|c|c|c|c|c|c|c|c|}
\hline & \multicolumn{7}{|c|}{ Year of Initial Operation } \\
\hline Module & Scenario 1 & Scenario 2 & Scenario 3 & Scenario 4 & Scenario 5 & Scenario 6 & Scenario 7 \\
\hline \multicolumn{7}{|c|}{ Surface Facilities } \\
\hline Phase 1 & 2010 & 2010 & 2010 & 2010 & 2010 & 2010 & 2010 \\
\hline Phase 2 & 2013 & 2013 & 2013 & 2013 & 2013 & 2012 & 2013 \\
\hline Phase 3 & 2013 & 2020 & 2013 & 2013 & 2018 & 2012 & 2015 \\
\hline & & Subsurface Facilities (First Emplacement) & \multicolumn{3}{|c|}{2010} & 2010 \\
\hline Panel 1 & 2010 & 2010 & 2010 & 2010 & 2010 & 2015 & 2012 & 2012 \\
\hline Panel 2 & 2012 & 2012 & 2020 & 2012 & 2012 & 2018 & 2018 \\
\hline Panel 3 & 2018 & 2018 & 2026 & 2018 & 2021 & 2024 & 2024 \\
\hline Panel 4 & 2024 & 2024 & 2032 & 2024 & 2027 & 20 \\
\hline
\end{tabular}

\subsection{REPOSITORY COST ANALYSIS}

This section describes how the repository annual costs were developed from the unit cost data and construction schedules. Detailed worksheets showing the annual breakdowns for repository costs are included in Appendix D. The Basis of Estimate for the repository costs are provided in references Board et al. 2002; Linden 2002; Brown 2002; and McDaniel 2002.

\subsubsection{General Assumptions}

- LA is submitted in December 2004.

- Three year NRC review of LA.

- Ability to begin certain pre-construction activities prior to CA.

- CA received in March 2008.

- Costs derived or taken from the May 2001 TSLCC are escalated from 2000 dollars to 2002 dollars using a factor of 1.044 . 
- The BSC Detailed Work Plan ("Plan B") is used for the FY 2002 through LA costs. The estimate from LA through start of waste acceptance is based on a level-of-effort staffing plan for each functional organization with the exception of the operations and maintenance $(\mathrm{O} \& M)$ cost.

- For the purposes of performing the cost analysis, receipt and emplacement rates were assumed to match the values given in Appendix $\mathrm{C}$ for each scenario. The inconsistencies between the preliminary construction schedules developed for the repository in the Design Evolution Study and the assumed receipt rates (noted in Section 5.2) were not considered.

\subsubsection{Construction Costs}

Direct costs for facilities that have changed from the SR design, per this study, are based on unit rates derived from the May 2001 TSLCC cost estimate. For the facilities that are unchanged from the SR design, the direct costs are based on the total direct cost values from the May 2001 TSLCC. The following is a list of adjustments to these direct cost values that account for the new M\&O business model and/or experience:

- A productivity factor adjustment is applied to the direct labor cost to account for slower productivity associated with "Q-Listed" facilities.

- A revised factor is applied to the direct cost to allow for the construction contractor's indirect cost (e.g., temporary facilities, supervision, small tools, equipment, supplies, etc.)

- A revised factor is applied to the direct cost to account for the M\&O's general and administrative cost (G\&A rate). This rate is consistent with the current M\&O business model.

- A factor is applied to the direct cost to allow for support services provided by the Nevada Test Site (NTS) during the construction phase of the project.

For Scenario 3, which assumed an 8 year delay in construction of Panels 2-4, an estimate of demobilization and mobilization costs for underground construction was included in the subsurface construction costs.

In order to allow for a direct comparison to the May 2001 TSLCC, WP spacing for all scenarios was assumed to be 0.1 meters, the value used in the TSLCC. Drip shield unit costs were calculated using the continuous drip shield model assumed in the May 2001 TSLCC. Note that the 0.1 meter WP spacing in the TSLCC resulted from a HTOM consistent with the SR surface facilities design (which included a 5,000 MTHM blending pool). The WP spacing that would result from a HTOM using the surface facilities design concept developed in the Design Evolution Study (which includes only about 400 MTHM of blending storage) has not been determined, due to the conceptual nature of the repository design and the current lack of a repository thermal operating strategy. This potential inconsistency was addressed in this study 
only to the extent that an additional 1,000 MTHM of surface blending storage was included in the cost analysis (see Section 5.2.1). Note that the available drift length in the first 4 subsurface panels is sufficient to accommodate 70,000 MTHM at up to 2 meter WP spacing. Since all 4 panels are assumed to be constructed regardless of the WP spacing, the subsurface construction costs are insensitive to the thermal operating mode. In addition, if the WPs were spaced significantly farther apart than 0.1 meters, a segmented drip shield would be used rather than the continuous drip shield costed in the this study. Therefore, the difference in total drip shield cost should not vary significantly with WP spacing.

The WP unit cost was assumed to be the average WP cost estimated in the May 2001 TSLCC, escalated to 2002 dollars $(\$ 0.465 \mathrm{M}$, including the pallet). The number of WPs emplaced each year was estimated from the nominal waste receipt rate by utilizing average assemblies (or canisters) per WP values for PWR CSNF, BWR CSNF, and defense wastes derived from the May 2001 TSLCC waste stream (DOE 2001b, Table B-2). This approximation is accurate to about 0.6 percent, as shown in Table 18 .

Table 18. Waste Package Model Results for Scenario 1

\begin{tabular}{|c|c|c|c|}
\hline Type of WP & May 2001 TSLCC & Scenario 1 & Delta (\%) \\
\hline CSNF & 9,919 & 10,000 & 0.8 \\
\hline HLW & $4,422^{1}$ & 4,247 & -4.0 \\
\hline Naval SNF & 300 & 300 & 0 \\
\hline Total & $14,641^{1}$ & 14,547 & -0.6 \\
\hline
\end{tabular}

1 Does not include 127 WPS (635 canisters) of immobilized plutonium included in TSLCC waste stream

\subsubsection{Operations and Maintenance Costs}

The O\&M costs are based on the May 2001 TSLCC estimate, adjusted for items included in other parts of the estimate. For example, Performance Confirmation and Testing and Regulatory, Infrastructure, and Management Support (RIMS)-related costs are included as separate line items, and are not included in this function. The procurement and installation of the drip shields is included in the monitoring phase of the project. O\&M costs were also adjusted for each scenario to account for variations in receipt and emplacement rates.

\subsubsection{Indirect Costs}

- Repository indirect costs include engineering, licensing, management support, administration, Payments Equivalent to Taxes (PETT), Benefits (i.e., payments to the state of Nevada and local governments), and Program Integration and Institutional (PI\&I) costs. In the May 2001 TSLCC, engineering, licensing, management support, and administration costs were rolled up into a cost category called RIMS. For this analysis, costs that were included as RIMS are now included in the cost estimate for each functional organization represented by the current $M \& O$ (e.g., functional directs, project management, license application, repository design, etc.). Functional directs include project controls, finance, administration, science, engineering, etc. 
PETT, Benefits and PI\&I costs used in this study were based on costs generated for the May 2001 TSLCC. The TSLCC costs are based on 31 years emplacement and 69 years monitoring (100 years total). These costs were adjusted for the 70,000 MTHM waste stream by deleting 2 years of emplacement period costs and adding 2 years of monitoring period costs. The TSLCC costs were then escalated to 2002 dollars, and the contingency factor was adjusted as described in Section 5.4. Institutional costs (Nuclear Waste Policy Act Section 180[c]) are included in the WAST cost estimate.

\subsection{COST CONTINGENCY FACTORS}

Contingency factors are typically added to cost estimates to compensate for uncertainties in the cost data and/or the estimating process. For this study, the contingency factors used in the May 2001 TSLCC were reviewed and adjusted as necessary to reflect the conceptual nature of the modular design concept. Based on this review, the contingency factors shown in Table 19 were assumed for this study. Note that contingency factors are assigned only after 2005.

Table 19. Cost Contingency Factors

\begin{tabular}{|l|c|}
\hline \multicolumn{1}{|c|}{ Cost Element } & $\begin{array}{c}\text { Contingency Factor } \\
\text { (percent) }\end{array}$ \\
\hline National Transportation & 25.0 \\
\hline Nevada Transportation & 25.0 \\
\hline Repository & 30.0 \\
\hline Program Management \& Integration & 19.7 \\
\hline Institutional & 30.0 \\
\hline
\end{tabular}




\section{EVALUATION OF SYSTEM DESIGN IMPLEMENTATION SCENARIOS}

This section describes the results of the evaluation of the system conceptual design implementation scenarios. Logistics results and cost results are presented, plus an evaluation of the results versus the programmatic assumptions listed in Section 2.

\subsection{LOGISTICS RESULTS}

Table 20 summarizes the logistics results for the 7 scenarios, as compared to the May 2001 TSLCC. Note that the Maximum CSNF Storage Capability in Table 20 is the amount of storage capability costed in the analysis, not the maximum actually in storage at any one time.

Table 20. Logistics Results

\begin{tabular}{|c|c|c|c|}
\hline Scenario & $\begin{array}{c}\text { Total CSNF Accepted, } \\
\text { 2010-20 } \\
\text { (MTHM) }\end{array}$ & $\begin{array}{c}\text { Total CSNF Emplaced, } \\
\text { 2010-20 } \\
\text { (MTHM) }\end{array}$ & $\begin{array}{c}\text { Maximum CSNF Storage } \\
\text { Capability } \\
\text { (MTHM) }\end{array}$ \\
\hline TSLCC & 25,200 & 25,200 & $5,000^{1}$ \\
\hline 1 & 25,200 & 25,200 & $1,400^{2}$ \\
\hline 2 & 10,000 & 10,000 & $1,400^{2}$ \\
\hline 3 & 25,200 & 4,800 & $21,400^{2}$ \\
\hline 4 & 33,610 & 33,610 & $1,400^{2}$ \\
\hline 5 & 11,250 & 11,250 & $1,400^{2}$ \\
\hline 6 & 12,600 & 12,600 & $1,400^{2}$ \\
\hline 7 & 19,800 & 19,800 & $1,400^{2}$ \\
\hline
\end{tabular}

${ }^{1}$ Pool storage for blending purposes

${ }^{2}$ Comprised of 400 MTHM pool storage, with the remainder in dry storage

Of the 7 scenarios, only scenarios 1, 3, and 4 meet or exceed the May 2001 TSLCC total receipt through 2020, and only scenarios 1 and 4 meet or exceed the May 2001 TSLCC total emplacement through 2020. Scenarios 5-7 fail to meet the TSLCC receipt and emplacement totals through 2020 due to the low initial receipt rate caused by delayed Nevada rail construction. Scenario 2 fails to meet the TSLCC total receipt and emplacement due to limiting the receipt rate for the first 10 years to the APR/ACR rate. Scenario 3 meets the TSLCC total receipt through 2020, but fails to meet the TSLCC total emplacement, due to the moratorium on emplacement from 2013-2019.

\subsection{COST RESULTS}

\subsubsection{Costs for 70,000 MTHM Receipt and Emplacement}

Table 21 summarizes the annual CRWMS future costs for the years 2002-2020 for the 7 scenarios, as compared to the May 2001 TSLCC (escalated to 2002 dollars). Table 22 shows the 
life cycle cost for emplacement of 70,000 MTHM. The historical costs were taken from the May 2001 TSLCC, escalated to 2002 dollars, and adjusted for actual FY 2001 expenditures.

Table 21. Annual CRWMS Future Costs, 2002-2020 (M 2002\$) ${ }^{1}$

\begin{tabular}{|c|c|c|c|c|c|c|c|c|}
\hline FY & TSLCC & Scen 1 & Scen 2 & Scen 3 & Scen 4 & Scen 5 & Scen 6 & Scen 7 \\
\hline 2002 & 470 & 380 & 380 & 380 & 380 & 380 & 380 & 380 \\
\hline 2003 & 530 & 530 & 530 & 530 & 530 & 530 & 530 & 530 \\
\hline 2004 & 680 & 640 & 640 & 640 & 640 & 640 & 640 & 640 \\
\hline 2005 & 790 & 640 & 640 & 640 & 560 & 630 & 630 & 630 \\
\hline 2006 & 780 & 710 & 660 & 710 & 730 & 670 & 670 & 670 \\
\hline 2007 & 1,460 & 990 & 920 & 990 & 1,000 & 710 & 740 & 770 \\
\hline 2008 & 1,520 & 1,090 & 980 & 1,040 & 1,100 & 790 & 840 & 1,010 \\
\hline 2009 & 1,630 & 1,430 & 1,340 & 1,260 & 1,420 & 1,010 & 1,160 & 1,380 \\
\hline 2010 & 1,120 & 1,540 & 1,520 & 1,290 & 1,720 & 1,060 & 1,370 & 1,480 \\
\hline 2011 & 890 & 1,390 & 1,200 & 1,250 & 1,470 & 1,100 & 1,350 & 1,350 \\
\hline 2012 & 960 & 1,370 & 1,110 & 1,210 & 1,250 & 1,120 & 1,200 & 1,020 \\
\hline 2013 & 1,100 & 1,200 & 1,010 & 1,080 & 1,290 & 1,040 & 1,110 & 1,150 \\
\hline 2014 & 1,070 & 1,350 & 1,050 & 1,100 & 1,500 & 1,000 & 1,200 & 1,310 \\
\hline 2015 & 1,110 & 1,380 & 1,070 & 1,090 & 1,530 & 900 & 1,060 & 1,280 \\
\hline 2016 & 1,130 & 1,400 & 1,110 & 1,050 & 1,520 & 1,140 & 1,090 & 1,420 \\
\hline 2017 & 1,090 & 1,400 & 1,110 & 1,220 & 1,520 & 1,270 & 1,170 & 1,420 \\
\hline 2018 & 1,110 & 1,260 & 1,120 & 1,210 & 1,390 & 1,290 & 1,140 & 1,250 \\
\hline 2019 & 1,080 & 1,260 & 1,190 & 1,220 & 1,400 & 1,380 & 1,220 & 1,230 \\
\hline 2020 & 1,070 & 1,250 & 1,080 & 1,250 & 1,400 & 1,310 & 1,280 & 1,200 \\
\hline $\begin{array}{c}\text { Total } \\
2002-10\end{array}$ & 8,970 & 7,930 & 7,610 & 7,470 & 8,070 & 6,410 & 6,950 & 7,490 \\
\hline $\begin{array}{c}\text { Total } \\
2002-20\end{array}$ & 19,570 & 21,190 & 18,640 & 19,150 & 22,340 & 17,960 & 18,780 & 20,110 \\
\hline $\begin{array}{c}\text { Peak } \\
2002-10\end{array}$ & 1,630 & 1,540 & 1,520 & 1,290 & 1,720 & 1,060 & 1,370 & 1,480 \\
\hline
\end{tabular}

${ }^{1}$ Costs rounded to the nearest $\$ 10$ million

Note that all of the scenarios exhibit lower total costs through 2010 than the May 2001 TSLCC, and all but Scenario 4 exhibit lower peak costs through 2010 . Scenarios 1, 4, and 7 exhibit higher total costs through 2020 than the May 2001 TSLCC.

Note that the annual cost results shown in Table 21 assume that the repository can receive and process waste at the rates given in Tables 15 and 16. As discussed in Section 5.2, the preliminary construction schedules developed in the Design Evolution Study, while meeting the goal of initial repository operation in 2010 , do not support the receipt of the quantities of waste in 2010 shown in Tables 15 and 16. Therefore, the annual costs shown in Table 21 for 2010 are 
likely overestimated. However, it is likely that processing rates could be accelerated in the near term such that the total costs through 2020 would not differ significantly from those given in Table 21.

Table 22. Life Cycle Cost for 70,000 MTHM Emplacement (B 2002\$)

\begin{tabular}{|c|c|c|c|c|c|c|}
\hline Scenario & Historical & WAST $^{\mathbf{1}}$ & $\begin{array}{c}\text { Nevada } \\
\text { Transportation }\end{array}$ & Repository & PI\& $^{\mathbf{2}}$ & Total \\
\hline 1 & 9.0 & 5.0 & 1.0 & 35.1 & 6.5 & 56.6 \\
\hline 2 & 9.0 & 5.1 & 1.0 & 35.1 & 5.4 & 55.5 \\
\hline 3 & 9.0 & 5.0 & 1.0 & 37.5 & 6.5 & 59.0 \\
\hline 4 & 9.0 & 5.1 & 1.0 & 35.1 & 6.5 & 56.6 \\
\hline 5 & 9.0 & 5.1 & 0.9 & 35.1 & 5.8 & 56.0 \\
\hline 6 & 9.0 & 5.1 & 0.9 & 35.1 & 5.8 & 55.9 \\
\hline 7 & 9.0 & 5.0 & 1.0 & 35.0 & 6.5 & 56.5 \\
\hline
\end{tabular}

${ }^{1}$ WAST $=$ Waste Acceptance, Storage, and Transportation

${ }^{2} \mathrm{PI} \& \mathrm{I}=$ Program Integration and Institutional

\subsubsection{Total Life Cycle Costs and Fee Adequacy}

\subsubsection{Total Life Cycle Cost Calculation}

In order to estimate the impacts of the modular repository design concept on Total System Life Cycle Costs and Fee Adequacy, the results for 70,000 MTHM emplacement were extended to 97,800 MTHM (83,800 CSNF, 14,000 defense), the total waste stream amount in the May 2001 TSLCC. The waste streams for the 7 scenarios were extended by adding additional years of acceptance at the maximum acceptance rate

The costs for the extended years of receipt and/or emplacement were estimated using costs for years with comparable receipt/emplacement rates. The increased amount of drift length required for 97,800 MTHM was accounted for by multiplying the additional WPs generated by the average WP length (including spacing between WPs). Note that at 0.1 meter spacing, the WPs for 97,800 MTHM require about 74,700 meters of emplacement drift length, which is within the total emplacement drift length for Panels $1-4$ (see Table 8). However, due to the uncertainty about the WP spacing required for a HTOM using the assumed surface facilities design (see Section 5.3.2), it was assumed that Panel 5 is constructed for all 97,800 MTHM scenarios. Additional drip shield costs were calculated from the additional number of WPs, and spread over the closure period. The total pre-closure period was kept the same for all scenarios. Once the adjusted future costs were calculated, the historical costs from the May 2001 TSLCC (adjusted for actual 2001 expenditures) were added to all scenarios. The receipt, storage, and emplacement rates for the 97,800 MTHM waste stream scenarios are given in Appendix C. The detailed cost calculations are included in the summary cost worksheets in Appendix D. Table 23 shows the resulting life cycle costs for the 7 scenarios and the May 2001 TSLCC. 
Table 23. Total Life Cycle Cost for 97,800 MTHM Emplacement (B 2002\$)

\begin{tabular}{|c|c|c|c|c|c|c|c|}
\hline Scenario & $\begin{array}{c}\text { Historical } \\
\text { Costs }\end{array}$ & WAST & $\begin{array}{c}\text { Nevada } \\
\text { Transportation }\end{array}$ & Repository & PI\&I & Total & $\begin{array}{c}\text { Delta to May } \\
\text { 2001 TSLCC }\end{array}$ \\
\hline $\begin{array}{c}\text { May 2001 } \\
\text { TSLCC }^{1}\end{array}$ & 9.0 & $6.2^{2}$ & 0.9 & 37.5 & $6.4^{3}$ & 60.0 & 0 \\
\hline 1 & 9.0 & 5.6 & 1.0 & 40.6 & 6.8 & 62.9 & 2.9 \\
\hline 2 & 9.0 & 5.7 & 1.0 & 40.2 & 6.0 & 61.9 & 1.9 \\
\hline 3 & 9.0 & 5.6 & 1.0 & 44.0 & 6.8 & 66.3 & 6.3 \\
\hline 4 & 9.0 & 5.2 & 1.0 & 40.6 & 6.8 & 62.6 & 2.5 \\
\hline 5 & 9.0 & 6.4 & 1.0 & 42.0 & 6.2 & 64.6 & 4.6 \\
\hline 6 & 9.0 & 6.4 & 1.0 & 41.0 & 6.2 & 63.5 & 3.4 \\
\hline 7 & 9.0 & 6.0 & 1.0 & 40.7 & 6.8 & 63.4 & 3.4 \\
\hline
\end{tabular}

${ }^{1}$ For the May 2001 TSLCC, FY 2001 costs have been included in historical costs.

2 Includes $\$ 0.5$ billion in 180 (c) costs which in the TSLCC were included in PI\&I

${ }^{3}$ Reduced by $\$ 0.5$ billion in 180 (c) costs transferred to WAST

As can be seen from Table 23 , the life cycle costs for the 7 scenarios are $\$ 1.9$ to $\$ 4.6$ billion higher than the May 2001 TSLCC. Repository costs are $\$ 2.7$ to $\$ 4.5$ billion higher. However, nearly all of the increase in repository costs result from the difference in assumed contingency factors between the May 2001 TSLCC ( 14\% for repository costs) and this study. Table 24 shows a summary comparison of repository costs without contingency for the 7 scenarios and the TSLCC.

Table 24. Repository Base Cost Comparison for 97,800 MTHM Emplacement

\begin{tabular}{|c|c|c|}
\hline Scenario & Repository Cost (B 2002\$) & $\begin{array}{c}\text { Delta to May 2001 } \\
\text { TSLCC }\end{array}$ \\
\hline May 2001 TSLCC & 31.9 & 0.0 \\
\hline 1 & 31.5 & -0.4 \\
\hline 2 & 31.5 & -0.4 \\
\hline 3 & 34.1 & 2.2 \\
\hline 4 & 31.5 & -0.4 \\
\hline 5 & 32.6 & 0.7 \\
\hline 6 & 31.8 & -0.1 \\
\hline 7 & 31.6 & -0.3 \\
\hline
\end{tabular}

Table 25 shows a reconciliation of the costs for Scenario 1 with the May 2001 TSLCC. In this table, the May 2001 TSLCC costs have been redistributed to match as closely as possible the Scenario 1 cost categories. 
Table 25. Scenario 1 and TSLCC Cost Reconciliation

\begin{tabular}{|c|c|c|c|}
\hline \multirow[t]{2}{*}{ Cost Element } & \multicolumn{3}{|c|}{ Millions of 2002 Dollars } \\
\hline & Scenario 1 & $\begin{array}{l}\text { May } 2001 \\
\text { TSLCC }^{1}\end{array}$ & Delta \\
\hline \multicolumn{4}{|c|}{ Repository } \\
\hline Project Support $^{2}$ & $\$ 11,269$ & $\$ 12,845$ & $-\$ 1,576$ \\
\hline Construction & $\$ 18,516$ & $\$ 17,848$ & $\$ 668$ \\
\hline Other ${ }^{3}$ & $\$ 1,715$ & $\$ 1,215$ & $\$ 501$ \\
\hline Contingency & $\$ 9,085$ & $\$ 5,957$ & $\$ 3,129$ \\
\hline TOTAL YMP - NEVADA & $\$ 40,586$ & $\$ 37,865$ & $\$ 2,721$ \\
\hline \multicolumn{4}{|c|}{ Waste Acceptance and Transportation (WAST) } \\
\hline Waste Acceptance and National Transportation & $\$ 5,597$ & $\$ 6,171$ & $-\$ 574$ \\
\hline Nevada Transportation & $\$ 968$ & $\$ 877$ & $\$ 92$ \\
\hline TOTAL WAST & $\$ 6,565$ & $\$ 7,047$ & $-\$ 483$ \\
\hline \multicolumn{4}{|c|}{ Program Integration and Institutional (PI\&l) } \\
\hline Program Integration & $\$ 2,233$ & $\$ 2,334$ & $-\$ 101$ \\
\hline Institutional & $\$ 3,174$ & $\$ 3,272$ & $-\$ 97$ \\
\hline Contingency & $\$ 1,343$ & $\$ 915$ & $\$ 427$ \\
\hline TOTAL PI\&I & $\$ 6,750$ & $\$ 6,521$ & $\$ 228$ \\
\hline GRAND TOTAL FUTURE COSTS & $\$ 53,900$ & $\$ 51,433$ & $\$ 2,467$ \\
\hline Historical Costs (1983-2000) & $\$ 8,587$ & $\$ 8,587$ & $\$ 0$ \\
\hline 2001 Costs & $\$ 417$ & $\$ 0$ & $\$ 417$ \\
\hline TSLCC & $\$ 62,904$ & $\$ 60,020$ & $\$ 2,884$ \\
\hline
\end{tabular}

1 Note that TSLCC costs include projected FY2001 costs, so cost deltas for individual categories may be slightly off.

2 Includes Functional Directs, Design, Repository O\&M, Licensing, Performance Assessment, Site Services, Procurement, Construction Management, Special Projects, and USGS

3 Includes Bechtel Nevada, YMP Program Direction, Set-Asides, and Miscellaneous Adjustments

The principal difference in base repository costs between the May 2001 TSLCC and Scenario 1 is due to lower Project Support costs in Scenario 1 (\$1.6 billion). This is due mostly to reestimation of the support costs included as RIMS costs in the TSLCC. In the "Other" cost category, Scenario 1 costs are $\$ 500$ million higher than the TSLCC, principally due to higher estimated "set-asides" (fees, etc). The largest cost difference, as discussed above, is in contingency costs.

Other differences between the TSLCC and Scenario 1 costs are in WAST, Nevada transportation, and PI\&I. The WAST cost differences ( $\$ 574$ million) mainly reflect the assumption of transport via dedicated trains in Scenario 1, rather than general freight as in the TSLCC. The differences in PI\&I costs reflect increased contingency costs, partially balanced by reductions in $2002-2005$ costs to reflect the Plan B budget. 


\subsubsection{Fee Adequacy Assessment}

A parametric assessment of Fee Adequacy was performed for the 7 scenarios analyzed in this study. Costs were split between civilian and defense funding sources utilizing data from the May 2001 TSLCC model (DOE 2001e), adjusted for the larger repository area. The results of the assessment indicated that there does not appear to be a Fee Adequacy concern with any of the scenarios.

\subsection{EVALUATION OF RESULTS VERSUS PROGRAMMATIC ASSUMPTIONS}

Table 26 shows the summary results of an evaluation of the recommended design concept as implemented by the 7 scenarios analyzed in this study versus the programmatic assumptions described in Section 2. A "green" ranking means that the implementation of the design fully satisfies the programmatic assumption or constraint. A "yellow" ranking means that some elements of the design implementation did not fully satisfy the programmatic assumption, although the overall ranking is acceptable. A "red" ranking means that the implementation of the design does not satisfy the assumption or constraint. A discussion of the areas that received a "yellow" or "red" ranking follows.

\section{Criterion}

2.1.3.B A high priority goal of the study is to develop a design concept that could allow initial emplacement of some CSNF (plus any or all of the other waste types described in 3.2.B, if possible) by 2010 , even under the constrained funding assumption in section 3.5 .

\section{Ranking: Green/Red}

\section{Discussion}

The design concept evaluated allowed the initial emplacement of all waste types analyzed by 2010 (green). However, the constrained funding limitation was not met (red) (see discussion of Criterion 2.1.4, below). 


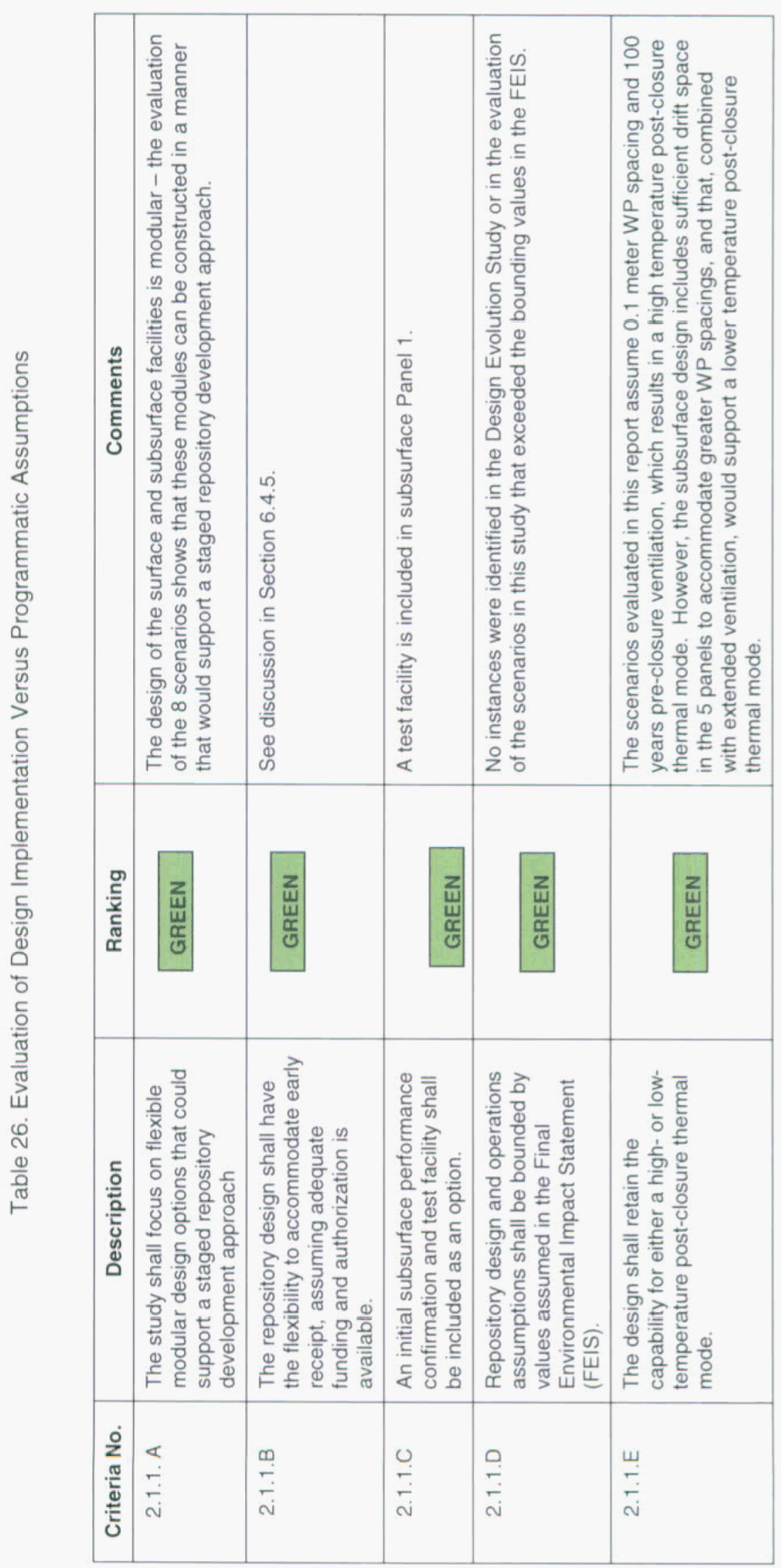




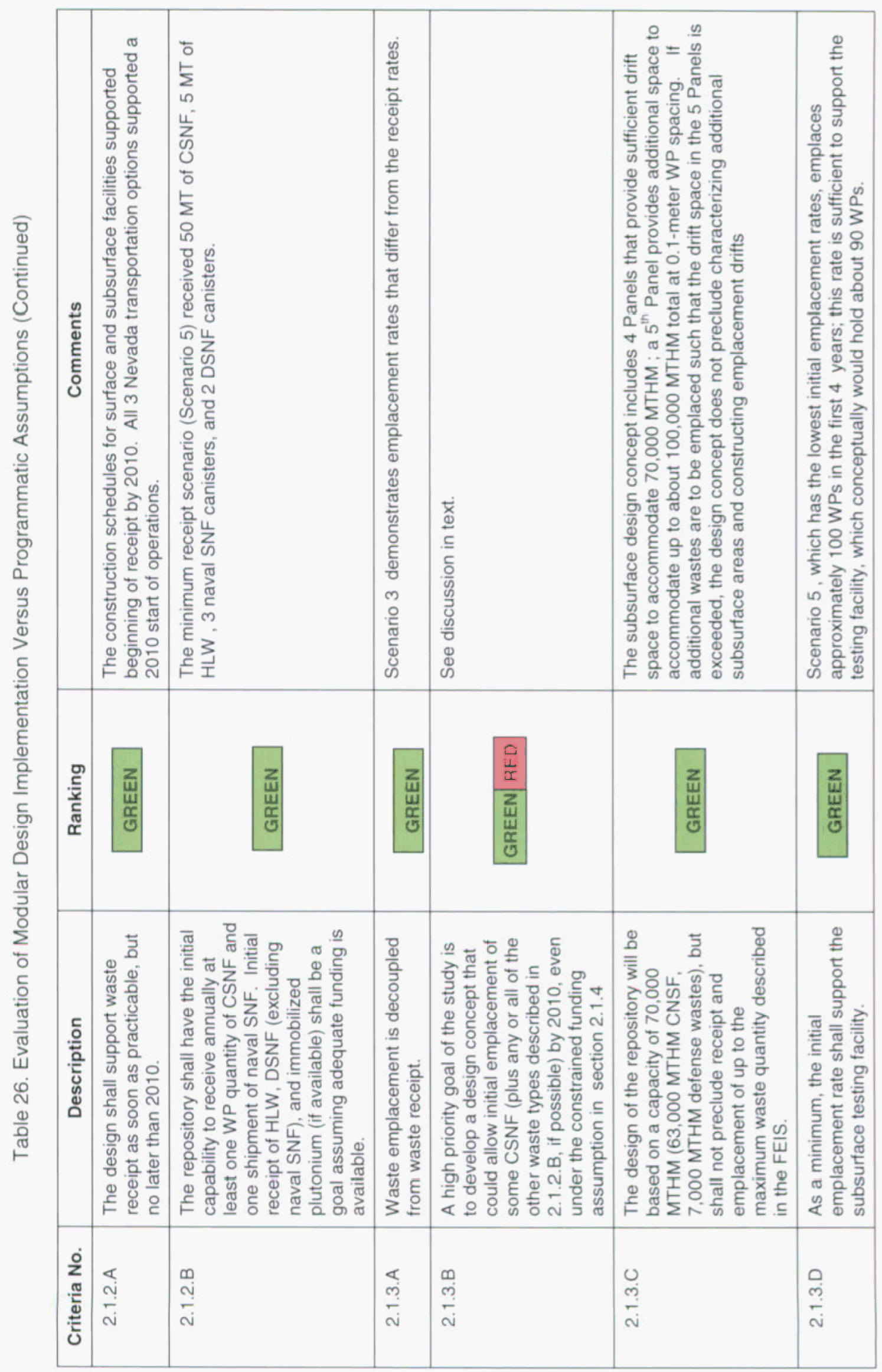




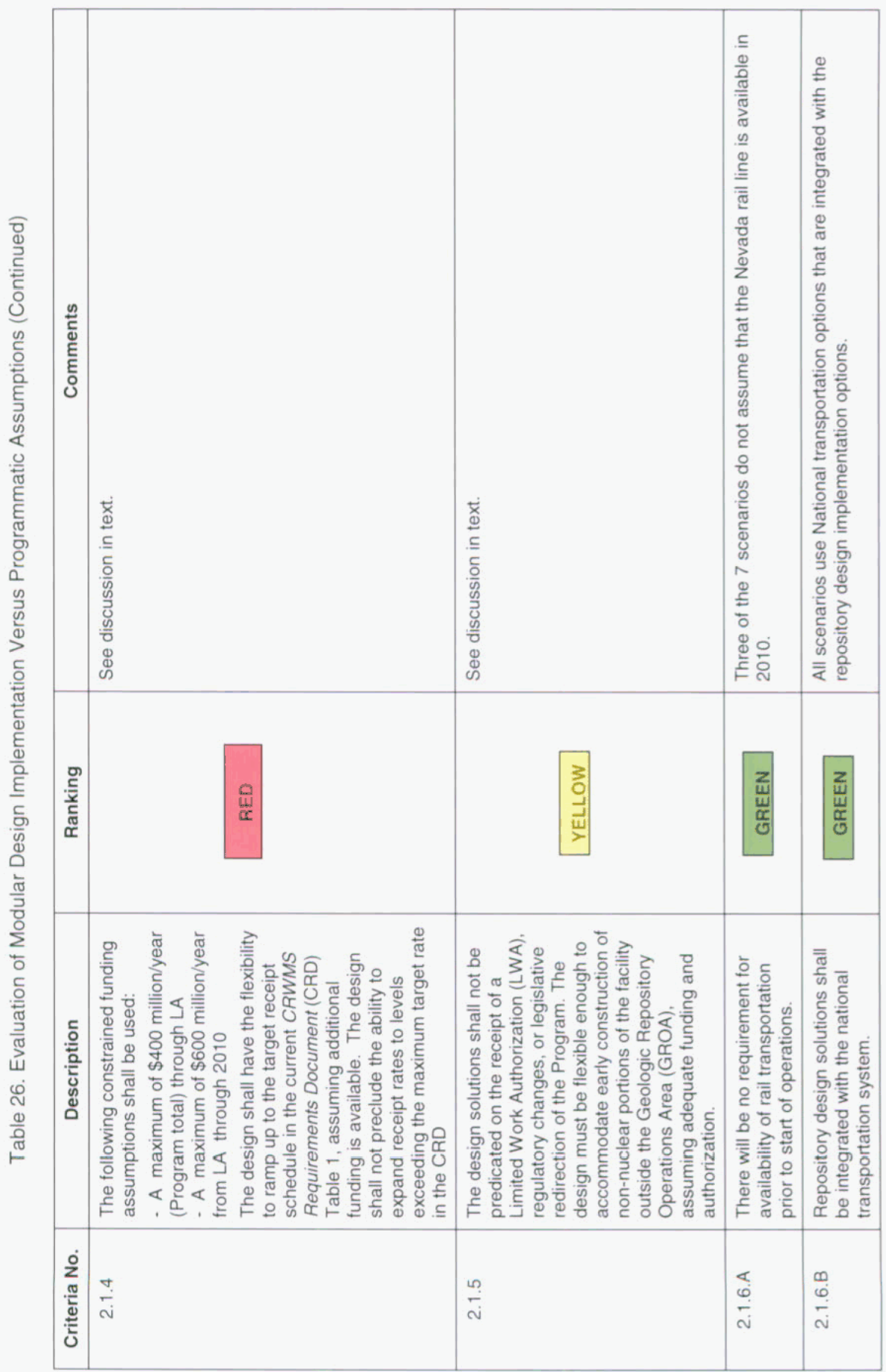




\section{Criterion}

2.1.4 The following constrained funding assumptions shall be used:

- A maximum of $\$ 400$ million/year (Program total) through LA

- A maximum of $\$ 600$ million/year from LA through 2010

The design shall have the flexibility to ramp up to the target receipt schedule in the current CRWMS Requirements Document (CRD) Table 1 (DOE 2001a), assuming additional funding is available. The design shall not preclude the ability to expand receipt rates to levels exceeding the maximum target rate in the CRD.

\section{Ranking: Red}

\section{Discussion}

The implementation scenarios demonstrated that the design concept has the flexibility to rampup to receipt and emplacement rates meeting and in some cases exceeding the CRD target rates by as much as 33 percent. However, the construction schedule developed for the repository design concept does not support initial receipt in 2010 at the target rate in the CRD (400 MTHM CSNF), even though for costing purposes this rate was assumed in several of the scenarios. In addition, the constrained funding assumption was not met in any of the scenarios analyzed. The minimum-capability scenario (Scenario 5) was intended to comply as far as possible with the constrained funding limit. As shown in Table 21, the maximum annual cost prior to 2010 for this scenario was $\$ 1.06$ billion, which significantly exceeded the $\$ 600$ million annual goal.

\section{Criterion}

2.1.5 The design solutions shall not be predicated on the receipt of a Limited Work Authorization (LWA), regulatory changes, or legislative redirection of the Program. However, the design must be flexible enough to accommodate early construction of nonnuclear portions of the facility outside the Geologic Repository Operations Area (GROA), assuming adequate funding and authorization.

\section{Ranking - Yellow}

\section{Discussion}

See Section 6.4 .3 below.

\subsection{LICENSING ISSUES}

In addition to the evaluation criteria described in Section 6.3, the design concept and its implementation in this study were examined with respect to licensability. The following licensability issues were identified during the design component sub-studies or the design implementation analysis conducted in this study: 


\subsubsection{Surface Facilities}

The Waste Handling Facility sub-study (Brown 2002, Appendix B) concluded that the recommended option (a dry waste handling facility with a small wet system for off-normal circumstances) involves some licensing risk due to the dry processing of large amounts of bare CSNF assemblies on a continual basis. However, the inclusion of a wet off-normal handling facility ameliorates this risk somewhat. The number of individual handling functions bears heavily on the perceived safety performance of the high throughput process. The NRC reviewers will scrutinize these functions with likely advantage given to the fewer processing steps, as present in the dry system. However, the uncertainties involved in the phased and separated modular design may combine to increase the risk of licensing.

\subsubsection{Aging}

The aging sub-study (McDaniel 2002) concluded that if Option C3 is selected for aging of CSNF (a new disposable canister that could be stored and then placed directly into a disposal overpack):

- Design and licensing of the disposal canister design would be required, which would parallel the design and licensing of the WPs. This would minimize the number of storage systems that would need to be licensed and deployed.

- The WHF would need to include new process steps for handling, inspecting, and welding the new disposal canisters.

An additional issue arose during the analysis of Scenario 3. If it is assumed that all subsurface construction is halted for several years after the initial test area is filled, waste received between 2013 and 2019 would either need to be stored at the repository, or acceptance would need to be halted during the emplacement moratorium. The aging sub-study did not include an analysis of surface storage for defense wastes. For the purposes of this study, it was assumed that defense wastes could be stored on the surface in "WP-sized" canisters with a concrete overpack (similar in design and cost to DPC storage for CSNF). Such storage systems for defense wastes do not currently exist, and would require development by DOE and licensing by the NRC. If it is decided to provide for storage of defense wastes at the repository, additional work would be required to determine the feasibility and cost of providing for storage.

The issue of whether storage (aging) facilities could be licensed as part of the repository under 10 CFR Part 63 is addressed in Appendix E.

\subsubsection{Design Implementation}

The preliminary construction schedules from the Design Evolution Study identified a number of early construction activities that would be required to meet a 2010 operations date. Examples of such activities are:

- Safety and infrastructure improvements 
- Support of ongoing testing and initiation of additional performance confirmation activities

- Site remediation activities.

Tables 7 and 11 show the activities identified in the Design Evolution Study for the Nevada rail and surface facilities, respectively. The Underground Layout Study (Board et al. 2002, Figure 57) also assumes on-site power upgrades and other BOP early construction activities. Further evaluation is being performed as part of the Critical Decision 1 (CD-1) effort to determine the extent to which early construction activities may be required.

\subsubsection{Phased Repository Construction}

Appendix E contains a detailed discussion of regulatory issues associated with phased construction and operation of the repository.

\subsubsection{Early Waste Receipt}

The Design Evolution Study Summary (Rowe 2002, Section 7) discussed the adaptability of the phased construction design concept to early receipt of waste (i.e., prior to 2010), assuming adequate funding and authorization are available. Two early receipt options were evaluated, as described below.

\section{Option 1 - Early Receipt and Emplacement}

The current LA schedule, along with the NRC review time, will not give the project a CA until March 2008. This would not provide sufficient time to construct the facilities necessary for early waste receipt and emplacement. Thus, any meaningful early receipt and emplacement would require a change to the decision strategy to submit the LA prior to 2004, and an expedited review by the NRC to allow starting construction prior to 2008 .

\section{Option 2 - Early Receipt Only}

Delay all subsurface work and simply construct a waste storage area at one or more of the potential sites identified in Figure 9. This surface storage would require a change to the Nuclear Waste Policy Act (NWPA) (DOE 1995b). The change would be necessary to remove the prohibitions and limitations that are contained in NWPA sections 135 (a) (1) and (2), and 141 (g), which prevent the storage of waste at Yucca Mountain prior to repository licensing. If such legislative relief were obtained, the NRC would need to conduct a conforming rulemaking to amend 10 CFR 63 to eliminate its corresponding prohibitions.

Even if the current NWPA storage prohibitions were to be removed, the Energy Reorganization Act, Section 202 (3) and (4), requires that DOE storage of commercial reactor spent fuel be licensed by the NRC. Two licensing options are presented: 
10 CFR 72 license -10 CFR 72 is the NRC regulation for storing spent fuel. Originally issued in the early 1980 s, this regulation accommodates both dry and wet storage, and stand-alone storage as well as storage at a licensed reactor site. If applied to Yucca Mountain, a specific Part 72 license could be issued to DOE after NRC review. However, if a request for hearing were granted by the Commission, a 10 CFR 2 Subpart G hearing would be held prior to license issuance. Such a hearing would take place if parties were admitted upon successful petition for leave to intervene, and if the assigned Atomic Safety and Licensing Board were to admit at least one contention for litigation. The high likelihood that Nevada and Clark County would petition successfully and participate in a hearing has the potential to introduce the significant schedule uncertainty in this endeavor.

Operate under DOE Orders - This option would require amendment to both the NWPA and the Energy Reorganization Act to allow DOE to receive and store the fuel without the requirement for NRC licensing. We would still need to address the issues concerning NEPA and the fact that 10 CFR 63 does not allow early fuel storage. This option would be counter to recent DOE actions at INEEL, which entail NRC licensing of spent fuel storage, and would likely draw opposition due to the lack of public access to the process. 
INTENTIONALLY LEFT BLANK 


\section{CONCLUSIONS AND RECOMMENDATIONS}

This section summarizes the results of the system design implementation analysis, and lists recommendations for alternative conceptual design solutions and/or changes in Program/Project requirements.

\subsection{CONCLUSIONS}

The Design Evolution Study (Rowe 2002) examined potential enhancements to the repository design that is presented in the Yucca Mountain Science and Engineering Report (S\&ER) (DOE 2001c). The study concluded that there are several enhancements that, if implemented, could potentially result in an improved repository design, lower peak costs, and increased flexibility. The design concept used in this study reflects the recommendations of the Design Evolution Study.

This study evaluated the implementation of the modular design concept using 7 receipt and emplacement scenarios. The scenarios tested the ability of the design concept to adapt to changes in funding, waste receipt/emplacement rate, and Nevada rail transportation availability.

The overall conclusion of this study is that the repository design concept recommended for further study in the Design Evolution Study (Rowe 2002) is adaptable and appears to be sufficiently flexible to encompass a variety of receipt rates, emplacement rates, transportation options, and funding profiles. Other conclusions are as follows:

1. Peak and total Program costs during the pre-operations period (through 2010) were reduced by utilizing a phased repository construction concept. Scenario 1, which has receipt and emplacement assumptions similar to those in the May 2001 TSLCC, reduced peak Program costs by $\$ 90$ million (6 percent) and total costs through 2010 by $\$ 1.0$ billion (12 percent) versus the SR design. Scenario 5 reduced peak costs by $\$ 570$ million (35 percent) and total costs by $\$ 2.6$ billion (29 percent), but at the cost of a substantial reduction in initial receipt capability. Note that without the assumed increase in contingency factors versus the May 2001 TSLCC, the cost differences for all scenarios would have been greater.

2. Repository design and construction costs represent about 24 percent of total Program costs through 2010. Therefore, even though these costs were reduced by almost 50 percent by phased construction in Scenario 1, the net reduction in total costs was only 12 percent.

3. The preliminary construction schedule developed for the Design Evolution Study, while supporting a 2010 operations date, does not support receipt of waste at the CRD target rates in 2010 (400 MTHM of CSNF). 
4. Once adjusted for differing contingency factors, estimated total life cycle costs for the 7 implementation scenarios are not significantly different than for the SR design modeled in the May 2001 TSLCC, particularly given the large uncertainties in the cost estimates.

5. The Nuclear Waste Fund Fee appears to be adequate for all of the scenarios.

6. The construction schedule developed for the Design Evolution Study identified a number of early construction activities that would improve confidence in meeting an operation date of 2010. Further evaluation is being performed as part of the Critical Decision 1 (CD-1) effort to more definitively determine the extent to which early construction activities are required.

7. Construction and operation of the repository in a phased manner appears to be consistent with the current regulatory requirements in 10 CFR 63.

8. The phased construction concept appears to be adaptable to early waste receipt, assuming adequate funding and authorization.

9. The design concept analyzed in this study did not meet the constrained funding criterion of $\$ 600$ million/year from LA through 2010. While this criterion was set somewhat arbitrarily, the minimum cost implementation scenario (Scenario 5) exceeded this goal by over $\$ 400$ million in 2009 . Contributing factors were the need to support a rapid rampup in waste receipt rate through 2015, and the fact that BOP cost phasing was not evaluated. However, given the fact that repository design and construction costs represent about 24 percent of the total Program costs through 2010, it is unlikely that the $\$ 600$ million/year goal can be met without reductions in Program costs other than design and construction.

10. The analysis of Scenario 3 involved a several-year moratorium on underground construction and emplacement after the filling of the test area in subsurface Panel 1. This required an assumption of either surface storage at the repository for defense wastes, or halting receipt of defense wastes during the emplacement moratorium. For the purposes of this study, it was assumed that surface storage of defense wastes would be employed. If such a feature were to be included in the repository design, storage casks for HLW and DSNF (including naval SNF) would need to be designed and licensed.

11. The cost analyses performed for this design concept were only rough order of magnitude (ROM) estimates, in that there was little or no "bottoms up" cost analysis performed due to lack of design detail and time constraints. Therefore, the life cycle costs generated in this study are useful only for comparative purposes.

\subsection{RECOMMENDATIONS}

The following recommendations were developed as a result of this study: 
1. As part of the preliminary design process, further evaluation of the repository design concept and more detailed estimates of BOP facilities' cost and construction schedules will be required to more accurately determine annual costs through 2010 .

2. As part of the preliminary design process, further evaluation of the repository construction schedule should be performed to more accurately determine the need for early construction activities and the receipt rate in the early years of operation.

3. As the design is refined further, more comprehensive life cycle cost and Fee Adequacy analyses should be performed, including development of a more detailed operations and maintenance (O\&M) cost model.

4. There is a need to evaluate other Program costs (besides repository design and construction), in order to further reduce the funding profile through 2010. 
INTENTIONALLY LEFT BLANK 


\section{REFERENCES}

Bebee. C. L. 2001. "Integrated Acceptance Schedule." E-mail from Corey L. Bebee (INEEL) to David Rhodes (BSC), July 19, 2001. ACC: MOV.20020206.0051.

Board, M. P.; Linden, A; and Zhu, M. 2002. Design Evolution Study-Underground Layout. TDR-MGR-MG-000003 REV 00. Las Vegas, Nevada: BSC. ACC: MOL.20020429.0023.

Brown, N. 2002. Design Evolution Study - Waste Handling Facility. TDR-MGR-MD-000010 REV 00. Las Vegas, Nevada: BSC. ACC: MOL.20020501.0415.

BSC (Bechtel SAIC Company, LLC ) 2001a. Program-Level Assumptions for the Preliminary System Design Alternatives Study for License Application. TDR-CRW-SE-000020 REV 00. Washington, D.C.: BSC. ACC: MOV.20020122.0003.

BSC 2001b Life Cycle Cost Analysis for Repository Flexible Design Concepts. TDR-CRW-SE000017 REV 00. Washington, D.C.: BSC. ACC: MOL.20011120.0951.

BSC 2001c. CRWMS Analysis and Logistics Visually Interactive Model, Version 3.1. Washington, D.C.: BSC. STN: 10074-3.1-00.

BSC 2002a. Technical Work Plan: Modular Design Implementation System Evaluation for License Application. TWP-CRW-SE-000009 REV 00. Washington, D.C.: BSC. ACC: MOV.20020403.0002.

BSC 2002b. National Transportation Options for the Modular Design Implementation System Evaluation for License Application. TDR-WAT-SE-000005 REV 00. Washington, D.C.: BSC. ACC: MOL.20020416.0054.

DOE (U.S. Department of Energy) 1995a. Acceptance Priority Ranking and Annual Capacity Report. DOE/RW-0457. Washington, D.C.: U.S. Department of Energy Office of Civilian Radioactive Waste Management. ACC: MOV.19960910.0021.

DOE 1995b. The Nuclear Waste Policy Act, As Amended With Appropriations Acts Appended. DOE/RW-0438 Rev. 1. Washington, D.C.: U.S. Department of Energy Office of Civilian Radioactive Waste Management. ACC: HQO.19950124.0001.

DOE 1999a. Draft Environmental Impact Statement for a Repository for the Disposal of Spent Nuclear Fuel and High-Level Radioactive Waste at Yucca Mountain, Nye County. Nevada. DOE/EIS-0250D. Summary, Volumes I and II. Washington, D.C.: U.S. Department of Energy Office of Civilian Radioactive Waste Management. ACC: MOL.19990816.0240. 
DOE 1999b. Waste Acceptance System Requirements Document. DOE/RW-0351 REV 03. Washington, D.C.: U.S. Department of Energy Office of Civilian Radioactive Waste Management. ACC: HQO.19990226.0001.

DOE 2001a. Civilian Radioactive Waste Management System Requirements Document. DOE/RW-0406 REV 05 DCN 04. Washington, D.C.: U.S. Department of Energy Office of Civilian Radioactive Waste Management. ACC: MOL.20010628.0243.

DOE 2001b. Total System Life Cycle Cost of the Civilian Radioactive Waste Management Program. ODE/RW-0533. Washington, D.C.: U.S. Department of Energy Office of Civilian Radioactive Waste Management. ACC: MOL.20010802.0217.

DOE 2001c Yucca Mountain Science and Engineering Report. DOE/RW-0539. Las Vegas, Nevada: U.S. Department of Energy Yucca Mountain Site Characterization Office. ACC: MOL MOL.20010524.0272.

DOE 2001d . Supplement to the Draft Environmental Impact Statement for a Geologic Repository for the Disposal of Spent Nuclear Fuel and High-Level Radioactive Waste at Yucca Mountain, Nye County, Nevada. DOE/EIS-0250D-S. Washington, D.C.: U.S. Department of Energy Office of Civilian Radioactive Waste Management. ACC: MOL.20010524.0184.

DOE 2001e. Nuclear Waste Fund Fee Adequacy: An Assessment. DOE/RW-0534. Washington, D.C.: U.S. Department of Energy Office of Civilian Radioactive Waste Management. ACC: MOV.20010607.0015.

DOE 2002. Final Environmental Impact Statement for a Geologic Repository for the Disposal of Spent Nuclear Fuel and High-Level Radioactive Waste at Yucca Mountain, Nye County. Nevada. DOE/EIS-0250. Washington, D.C.: U.S. Department of Energy Office of Civilian Radioactive Waste Management. ACC: MOL.20020207.0334 through MOL.20020207.0349.

Gehner, P. 2002. Nevada Transportation Options Study. TDR-OSS-SE-000001 REV 00. Las Vegas, Nevada: BSC. ACC: MOL.20020429.0315.

Linden, C. 2002. Design Evolution Study - In-Drift Configuration. TDR-MGR-MD-000008 REV 00. Las Vegas, Nevada: BSC. ACC: MOL.20020429.0022.

McDaniel, P. 2002. Design Evolution Study - Aging Options. TDR-MGR-MD-000011 REV 00. Las Vegas, Nevada: BSC. ACC: MOL.20020429.0316.

Rowe, G. 2002. Design Evolution Study - Summary. TDR-MGR-MD-000013 REV 00 Las Vegas, Nevada: BSC. ACC: MOL.20020530.0076.

Silva, R. A. and Stanley, B. T. 2002. Design Evolution Study - Waste Emplacement. TDR-MGRME-000002 REV 00. Las Vegas, Nevada: BSC. ACC: MOL.20020429.0313. 
Waisley, S. 2001. "Technical Direction to Bechtel SAIC Company, LLC, Contract Number DEAC08-01RW12101; TDL No. 02-003." Letter from S. Waisley (DOE) to K. Hess (BSC).

November 2, 2001, with attachments. ACC: HQO.20011109.0001. 
INTENTIONALLY LEFT BLANK 
APPENDIX A

YFF10 CSNF SELECTION CRITERION 
INTENTIONALLY LEFT BLANK 


\section{APPENDIX A - YFF10 CSNF SELECTION CRITERION}

1. Casks are selected based on priority (from highest to lowest). The highest priority cask usually has the largest capacity (and lowest heat limit) that can be handled at the site. Assemblies are then selected based on the YFF10 method (youngest fuel 10 years old or older selected first) and are tested against the cask limits.

2. Assemblies that pass the cask limit tests are loaded. Assemblies that fail the cask limit test are rejected.

- If sufficient acceptable assemblies cannot be located in the pool to fill the allocation, assemblies are taken from dry storage.

- If sufficient acceptable assemblies cannot be located in dry storage, fuel younger than 10 years old will be selected from the pool starting at the minimum acceptable fuel age and working up to 10 years old.

- If the current cask still cannot be filled, the desired fuel age is reset to 10 years, the next priority cask (usually a smaller, more robust design) is chosen, and the assembly selection/testing is repeated.

- Once sufficient assemblies have been loaded to fill the allocation, the next pool is selected. Note that if sufficient acceptable assemblies cannot be loaded, the pool's remaining allocation will be deferred to the next year. 
INTENTIONALLY LEFT BLANK 
APPENDIX B

TRANSPORTATION SCENARIOS ANNUAL COSTS 
INTENTIONALLY LEFT BLANK 


\section{APPENDIX B - TRANSPORTATION SCENARIOS ANNUAL COSTS}

This appendix contains the costs developed for the national transportation scenarios that were included in this study. The annual costs are shown in Table B-1 and the total costs are shown in Table B-2. These results were taken from reference BSC $2002 \mathrm{~b}$.

Table B-1. Annual Costs for National Transportation Scenarios

\begin{tabular}{|c|c|c|c|c|c|c|}
\hline \multirow[t]{2}{*}{ Year } & \multicolumn{6}{|c|}{ Millions of 2001 Dollars } \\
\hline & $1 \mathrm{~B}$ & $3 B$ & $4 A$ & $5 A$ & $7 \mathrm{~A}$ & $7 \mathrm{D}$ \\
\hline $2002^{1}$ & 2.8 & 2.8 & 2.8 & 2.8 & 2.8 & 2.8 \\
\hline $2003^{1}$ & 8.9 & 8.9 & 8.9 & 5.2 & 5.2 & 5.2 \\
\hline $2004^{1}$ & 15.2 & 15.2 & 15.2 & 5.6 & 5.6 & 5.6 \\
\hline $2005^{1}$ & 13.0 & 13.0 & 13.0 & 8.3 & 8.3 & 8.3 \\
\hline 2006 & 17.6 & 37.9 & 37.9 & 18.5 & 18.5 & 18.5 \\
\hline 2007 & 13.6 & 46.6 & 46.6 & 14.5 & 14.5 & 14.5 \\
\hline 2008 & 48.6 & 92.2 & 93.7 & 31.7 & 36.1 & 36.1 \\
\hline 2009 & 78.3 & 123.9 & 133.6 & 45.8 & 59.0 & 59.0 \\
\hline 2010 & 144.5 & 125.9 & 142.9 & 36.3 & 51.8 & 85.6 \\
\hline 2011 & 137.1 & 148.6 & 167.7 & 47.3 & 66.2 & 109.3 \\
\hline 2012 & 145.3 & 176.9 & 199.6 & 59.5 & 77.5 & 106.4 \\
\hline 2013 & 145.7 & 192.8 & 226.0 & 99.4 & 120.6 & 141.1 \\
\hline 2014 & 131.8 & 190.5 & 228.3 & 120.7 & 138.2 & 174.6 \\
\hline 2015 & 132.5 & 197.6 & 238.9 & 128.4 & 128.2 & 208.2 \\
\hline 2016 & 129.3 & 181.0 & 204.7 & 146.1 & 134.0 & 190.9 \\
\hline 2017 & 142.3 & 192.3 & 216.9 & 175.9 & 171.4 & 200.6 \\
\hline 2018 & 140.3 & 186.5 & 219.2 & 199.4 & 196.8 & 192.1 \\
\hline 2019 & 164.6 & 179.1 & 219.1 & 201.3 & 207.3 & 195.4 \\
\hline 2020 & 159.8 & 180.9 & 226.7 & 216.4 & 217.7 & 181.2 \\
\hline 2021 & 183.4 & 183.4 & 221.7 & 212.9 & 209.1 & 185.1 \\
\hline 2022 & 188.5 & 182.2 & 228.0 & 213.2 & 203.9 & 185.0 \\
\hline 2023 & 204.7 & 184.5 & 230.6 & 207.6 & 206.2 & 187.8 \\
\hline 2024 & 200.9 & 182.9 & 229.8 & 207.0 & 204.7 & 184.4 \\
\hline 2025 & 211.1 & 185.2 & 234.9 & 210.0 & 213.6 & 192.3 \\
\hline 2026 & 199.6 & 192.8 & 226.0 & 213.9 & 215.4 & 182.5 \\
\hline 2027 & 199.3 & 179.8 & 202.4 & 214.8 & 217.8 & 191.3 \\
\hline 2028 & 185.1 & 169.7 & 107.5 & 217.5 & 216.3 & 191.5 \\
\hline
\end{tabular}


Table B-1. Annual Costs for National Transportation Scenarios (Continued)

\begin{tabular}{|c|c|c|c|c|c|c|}
\hline \multirow[t]{2}{*}{ Year } & \multicolumn{6}{|c|}{ Millions of 2001 Dollars } \\
\hline & $1 \mathrm{~B}$ & $3 B$ & $4 A$ & $5 A$ & $7 A$ & 7D \\
\hline 2029 & 186.4 & 170.9 & 53.6 & 226.1 & 226.9 & 177.9 \\
\hline 2030 & 195.2 & 171.2 & 75.5 & 235.1 & 224.8 & 179.0 \\
\hline 2031 & 189.8 & 173.5 & 50.5 & 231.9 & 219.9 & 181.4 \\
\hline 2032 & 192.2 & 169.2 & 65.8 & 210.9 & 202.6 & 176.6 \\
\hline 2033 & 195.3 & 142.6 & 51.8 & 204.0 & 202.2 & 174.6 \\
\hline 2034 & 190.2 & 60.6 & 59.4 & 192.1 & 178.9 & 166.9 \\
\hline 2035 & 191.6 & 55.8 & 57.3 & 102.1 & 85.8 & 89.8 \\
\hline 2036 & 142.5 & 43.1 & 52.8 & 49.9 & 52.7 & 51.3 \\
\hline 2037 & 46.8 & 40.1 & 47.0 & 75.3 & 64.5 & 71.4 \\
\hline 2038 & 34.6 & 39.9 & 45.6 & 49.2 & 32.0 & 32.0 \\
\hline 2039 & 28.7 & 5.4 & 8.3 & 47.5 & 39.5 & 46.3 \\
\hline 2040 & 16.3 & 0.0 & 0.0 & 23.8 & 22.6 & 20.1 \\
\hline Total & $4,953.3$ & $4,825.6$ & $5,415.8$ & $4,908.0$ & $4,899.3$ & $4,802.7$ \\
\hline
\end{tabular}

1 Note: $2002-2005$ costs were not used in the total system cost analysis; current budget numbers were used instead. 
RECEIPT AND EMPLACEMENT SCENARIOS 
INTENTIONALLY LEFT BLANK 


\section{APPENDIX C - RECEIPT AND EMPLACEMENT SCENARIOS}

This appendix lists the nominal receipt, storage, and emplacement rates for the scenarios used in this study. Section C.1 gives the data for the 70,000 MTHM waste stream, and Section C.2 shows data as expanded for a 97,800 MTHM waste stream.

\section{C.1 70,000 MTHM WASTE STREAM}

Table C-1. Scenario 1 Nominal CSNF Receipt, Storage, and Emplacement Rates

\begin{tabular}{|c|c|c|c|}
\hline Year & $\begin{array}{c}\text { Receipt Rate } \\
\text { (MTHM/yr) }\end{array}$ & $\begin{array}{c}\text { Storage } \\
\text { Rate } \\
\text { (MTHM/yr) }\end{array}$ & $\begin{array}{c}\text { Emplacement Rate } \\
\text { (MTHM/yr) }\end{array}$ \\
\hline 2010 & 400 & 0 & 400 \\
\hline 2011 & 600 & 0 & 600 \\
\hline 2012 & 1,200 & 0 & 1,200 \\
\hline 2013 & 2,000 & 0 & 2,000 \\
\hline 2014 & 3,000 & 0 & 3,000 \\
\hline $2015-2032$ & 3,000 & 0 & 3,000 \\
\hline 2033 & 1,800 & 0 & 1,800 \\
\hline Total & 63,000 & 0 & 63,000 \\
\hline
\end{tabular}

Table C-2. Scenario 1, 2, and 4 Defense Wastes Receipt/Emplacement Rates

\begin{tabular}{|c|c|c|c|}
\hline Year & HLW (MTHM/year) & $\begin{array}{c}\text { Naval SNF } \\
\text { (Canisters/Year) }\end{array}$ & $\begin{array}{c}\text { Other DSNF } \\
\text { (Canisters/Year) }\end{array}$ \\
\hline 2010 & 127.5 & 3 & 18 \\
\hline 2011 & 220 & 3 & 41 \\
\hline 2012 & 220 & 6 & 76 \\
\hline 2013 & 220 & 6 & 76 \\
\hline 2014 & 235 & 12 & 76 \\
\hline 2015 & 235 & 14 & 76 \\
\hline 2016 & 220 & 14 & 76 \\
\hline 2017 & 235 & 14 & 86 \\
\hline 2018 & 245 & 14 & 129 \\
\hline 2019 & 367.5 & 14 & 130 \\
\hline 2020 & 357.5 & 14 & 129 \\
\hline 2021 & 322.5 & 14 & 138 \\
\hline 2022 & 360 & 14 & \\
\hline
\end{tabular}


Table C-2. Scenario 1, 2, and 4 Defense Wastes Receipt/Emplacement Rates (Continued)

\begin{tabular}{|c|c|c|c|}
\hline Year & HLW (MTHM/year) & $\begin{array}{c}\text { Naval SNF } \\
\text { (Canisters/Year) }\end{array}$ & $\begin{array}{c}\text { Other DSNF } \\
\text { (Canisters/Year) }\end{array}$ \\
\hline 2023 & 357.5 & 14 & 143 \\
\hline 2024 & 370 & 14 & 148 \\
\hline 2025 & 377.5 & 14 & 151 \\
\hline 2026 & 197 & 14 & 153 \\
\hline 2027 & 0 & 14 & 152 \\
\hline 2028 & 0 & 14 & 105 \\
\hline 2029 & 0 & 14 & 105 \\
\hline 2030 & 0 & 15 & 105 \\
\hline 2031 & 0 & 15 & 50 \\
\hline 2032 & 0 & 15 & 66 \\
\hline 2033 & 0 & 15 & 116 \\
\hline 2034 & 0 & 0 & 103 \\
\hline 2035 & 0 & 0 & 66 \\
\hline 2036 & 0 & 0 & 49 \\
\hline 2037 & 0 & 0 & 49 \\
\hline 2038 & 0 & 0 & 24 \\
\hline Total & 4667 & 300 & 2698 \\
\hline
\end{tabular}

Table C-3. Scenario 2 Nominal CSNF Receipt, Storage, and Emplacement Rates

\begin{tabular}{|c|c|c|c|}
\hline Year & $\begin{array}{c}\text { Receipt Rate } \\
\text { (MTHM/yr) }\end{array}$ & $\begin{array}{c}\text { Storage } \\
\text { Rate } \\
\text { (MTHM/yr) }\end{array}$ & $\begin{array}{c}\text { Emplacement Rate } \\
\text { (MTHM/yr) }\end{array}$ \\
\hline 2010 & 400 & 0 & 400 \\
\hline 2011 & 600 & 0 & 600 \\
\hline $2012-2019$ & 900 & 0 & 900 \\
\hline 2020 & 1,800 & 0 & 1,800 \\
\hline 2021 & 2,200 & 0 & 2,200 \\
\hline 2022 & 2,600 & 0 & 2,600 \\
\hline 2023 & 3,000 & 0 & 3,000 \\
\hline $2024-2035$ & 3,600 & 0 & 3,600 \\
\hline 2036 & 2,000 & 0 & 2,000 \\
\hline Total & 63,000 & 0 & 63,000 \\
\hline
\end{tabular}


Table C-4. Scenario 3 Nominal CSNF Receipt, Storage, and Emplacement Rates

\begin{tabular}{|c|c|c|c|}
\hline Year & $\begin{array}{c}\text { Receipt Rate } \\
\text { (MTHM/yr) }\end{array}$ & $\begin{array}{c}\text { Storage Rate } \\
\text { (MTHM/yr) }\end{array}$ & $\begin{array}{c}\text { Emplacement Rate } \\
\text { (MTHM/yr) }\end{array}$ \\
\hline 2010 & 400 & 0 & 400 \\
\hline 2011 & 600 & 0 & 600 \\
\hline 2012 & 1,200 & 1,000 & 200 \\
\hline 2013 & 2,000 & 2,000 & 0 \\
\hline $2014-2019$ & 3,000 & 3,000 & 0 \\
\hline $2020-2032$ & 3,000 & 0 & 3,600 \\
\hline 2033 & 1,800 & 0 & 3,600 \\
\hline $2034-36$ & 0 & 0 & 3,600 \\
\hline 2037 & 0 & 0 & 600 \\
\hline Total & 63,000 & 21,000 & 63,000 \\
\hline
\end{tabular}

Table C-5. Scenario 3 Nominal Defense Waste Receipt, Storage, and Emplacement Rates

\begin{tabular}{|c|c|c|c|c|c|c|c|c|c|}
\hline \multirow{2}{*}{ Year } & \multicolumn{3}{|c|}{ Receipt Rate } & \multicolumn{3}{c|}{ Storage Rate } & \multicolumn{3}{c|}{ Emplacement Rate } \\
\cline { 2 - 10 } & $\begin{array}{c}\text { HLW } \\
\text { (MTH/ } / \\
\text { yr) }\end{array}$ & $\begin{array}{c}\text { Naval } \\
\text { SNF } \\
\text { (Can/yr) }\end{array}$ & $\begin{array}{c}\text { DSNF } \\
\text { (Can/yr) }\end{array}$ & $\begin{array}{c}\text { HLW } \\
\text { (MTHM/ } / \\
\text { yr) }\end{array}$ & $\begin{array}{c}\text { Naval } \\
\text { SNF } \\
\text { (Can/yr) }\end{array}$ & $\begin{array}{c}\text { DSNF } \\
\text { (Can/yr) }\end{array}$ & $\begin{array}{c}\text { HLW } \\
\text { (MTHM/ } \\
\text { yr) }\end{array}$ & $\begin{array}{c}\text { Naval } \\
\text { SNF } \\
\text { (Can/yr) }\end{array}$ & $\begin{array}{c}\text { DSNF } \\
\text { (Can/yr) }\end{array}$ \\
\hline 2010 & 97.5 & 3 & 18 & 0.0 & 0 & 0 & 97.5 & 3 & 18 \\
\hline 2011 & 190 & 3 & 41 & 0.0 & 0 & 0 & 190.0 & 3 & 41 \\
\hline 2012 & 190 & 6 & 62 & 158.3 & 5 & 52 & 31.7 & 1 & 10 \\
\hline 2013 & 190 & 6 & 76 & 190.0 & 6 & 76 & 0.0 & 0 & 0 \\
\hline 2014 & 205 & 12 & 76 & 205.0 & 12 & 76 & 0.0 & 0 & 0 \\
\hline 2015 & 205 & 14 & 76 & 205.0 & 14 & 76 & 0.0 & 0 & 0 \\
\hline 2016 & 190 & 14 & 76 & 190.0 & 14 & 76 & 0.0 & 0 & 0 \\
\hline 2017 & 205 & 14 & 76 & 205.0 & 14 & 76 & 0.0 & 0 & 0 \\
\hline 2018 & 215 & 14 & 86 & 215.0 & 14 & 86 & 0.0 & 0 & 0 \\
\hline 2019 & 337.5 & 14 & 129 & 337.5 & 14 & 129 & 0.0 & 0 & 0 \\
\hline 2020 & 340 & 14 & 130 & 0.0 & 0 & 0 & 408.0 & 17 & 156 \\
\hline 2021 & 322.5 & 14 & 129 & 0.0 & 0 & 0 & 387.0 & 17 & 155 \\
\hline 2022 & 360 & 14 & 138 & 0.0 & 0 & 0 & 432.0 & 17 & 166 \\
\hline 2023 & 357.5 & 14 & 143 & 0.0 & 0 & 0 & 429.0 & 17 & 172 \\
\hline 2024 & 370 & 14 & 148 & 0.0 & 0 & 0 & 444.0 & 17 & 178 \\
\hline 2025 & 377.5 & 14 & 151 & 0.0 & 0 & 0 & 453.0 & 17 & 181 \\
\hline 2026 & 382.5 & 14 & 153 & 0.0 & 0 & 0 & 459.0 & 17 & 184 \\
\hline 2027 & 132 & 14 & 152 & 0.0 & 0 & 0 & 459.0 & 17 & 182 \\
\hline
\end{tabular}


Table C-5. Scenario 3 Nominal Defense Waste Receipt, Storage, and Emplacement Rates (Continued)

\begin{tabular}{|c|c|c|c|c|c|c|c|c|c|}
\hline \multirow{2}{*}{ Year } & \multicolumn{3}{|c|}{ Receipt Rate } & \multicolumn{3}{c|}{ Storage Rate } & \multicolumn{3}{c|}{ Emplacement Rate } \\
\cline { 2 - 10 } & $\begin{array}{c}\text { HLW } \\
(\mathbf{M T H M} / \\
\mathbf{y r})\end{array}$ & $\begin{array}{c}\text { Naval } \\
\text { SNF } \\
(\mathbf{C a n} / \mathbf{y r})\end{array}$ & $\begin{array}{c}\text { DSNF } \\
\text { (Can/yr) }\end{array}$ & $\begin{array}{c}\text { HLW } \\
\text { (MTHM/ } \\
\text { yr) }\end{array}$ & $\begin{array}{c}\text { Naval } \\
\text { SNF } \\
(\text { Can/yr) }\end{array}$ & $\begin{array}{c}\text { DSNF } \\
\text { (Can/yr) }\end{array}$ & $\begin{array}{c}\text { HLW } \\
\text { (MTHM/ } / \\
\text { yr) }\end{array}$ & $\begin{array}{c}\text { Naval } \\
\text { SNF } \\
\text { (Can/yr) }\end{array}$ & $\begin{array}{c}\text { DSNF } \\
\text { (Can/yr) }\end{array}$ \\
\hline 2028 & 0 & 14 & 105 & 0.0 & 0 & 0 & 459.0 & 17 & 126 \\
\hline 2029 & 0 & 14 & 105 & 0.0 & 0 & 0 & 418.0 & 17 & 126 \\
\hline 2030 & 0 & 15 & 105 & 0.0 & 0 & 0 & 0.0 & 18 & 126 \\
\hline 2031 & 0 & 15 & 50 & 0.0 & 0 & 0 & 0.0 & 18 & 60 \\
\hline 2032 & 0 & 15 & 66 & 0.0 & 0 & 0 & 0.0 & 18 & 79 \\
\hline 2033 & 0 & 15 & 116 & 0.0 & 0 & 0 & 0.0 & 18 & 139 \\
\hline 2034 & 0 & 0 & 103 & 0.0 & 0 & 0 & 0.0 & 18 & 124 \\
\hline 2035 & 0 & 0 & 66 & 0.0 & 0 & 0 & 0.0 & 18 & 79 \\
\hline 2036 & 0 & 0 & 49 & 0.0 & 0 & 0 & 0.0 & 15 & 59 \\
\hline 2037 & 0 & 0 & 49 & 0.0 & 0 & 0 & 0.0 & 0 & 59 \\
\hline 2038 & 0 & 0 & 24 & 0.0 & 0 & 0 & 0.0 & 0 & 278 \\
\hline Total & $4,667.0$ & 300 & 2,698 & $1,705.8$ & 93 & 647 & $4,667.2$ & 300 & 2,698 \\
\hline
\end{tabular}

Table C-6. Scenario 4 Nominal CSNF Receipt, Storage, and Emplacement Rates

\begin{tabular}{|c|c|c|c|}
\hline Year & $\begin{array}{c}\text { Receipt Rate } \\
\text { (MTHM/yr) }\end{array}$ & $\begin{array}{c}\text { Storage Rate } \\
\text { (MTHM/yr) }\end{array}$ & $\begin{array}{c}\text { Emplacement Rate } \\
\text { (MTHM/yr) }\end{array}$ \\
\hline 2010 & 533 & 0 & 533 \\
\hline 2011 & 800 & 0 & 800 \\
\hline 2012 & 1,600 & 0 & 1,600 \\
\hline 2013 & 2,677 & 0 & 2,677 \\
\hline $2014-2027$ & 4,000 & 0 & 4,000 \\
\hline 2028 & 1,390 & 0 & 1,390 \\
\hline Total & 63,000 & 0 & 63,000 \\
\hline
\end{tabular}


Table C-7. Scenario 5 Nominal Receipt, Storage, and Emplacement Rates

\begin{tabular}{|c|c|c|c|c|c|c|}
\hline \multirow[t]{2}{*}{ Year } & \multicolumn{3}{|c|}{ CSNF } & \multicolumn{3}{|c|}{ Receipt/Emplacement Rate } \\
\hline & \begin{tabular}{|c|} 
Receipt \\
Rate \\
(MTHM/yr)
\end{tabular} & $\begin{array}{c}\text { Storage } \\
\text { Rate } \\
\text { (MTHM/yr) }\end{array}$ & $\begin{array}{c}\text { Emplacement } \\
\text { Rate (MTHM/yr) }\end{array}$ & $\begin{array}{c}\text { HLW } \\
\text { (MTHM/year) }\end{array}$ & $\begin{array}{c}\text { Naval SNF } \\
\text { (Canisters/Year) }\end{array}$ & $\begin{array}{l}\text { Other DSNF } \\
\text { (Canisters/year) }\end{array}$ \\
\hline 2010 & 50 & 0 & 50 & 5 & 3 & 2 \\
\hline 2011 & 100 & 0 & 100 & 10 & 3 & 4 \\
\hline 2012 & 100 & 0 & 100 & 10 & 6 & 4 \\
\hline 2013 & 100 & 0 & 100 & 10 & 6 & 4 \\
\hline 2014 & 100 & 0 & 100 & 10 & 12 & 4 \\
\hline 2015 & 400 & 0 & 400 & 128 & 14 & 18 \\
\hline 2016 & 600 & 0 & 600 & 220 & 14 & 41 \\
\hline 2017 & 1,200 & 0 & 1,200 & 220 & 14 & 62 \\
\hline 2018 & 2,000 & 0 & 2,000 & 220 & 14 & 76 \\
\hline 2019 & 3,000 & 0 & 3,000 & 235 & 14 & 76 \\
\hline 2020 & 3,600 & 0 & 3,600 & 235 & 14 & 76 \\
\hline 2021 & 3,600 & 0 & 3,600 & 220 & 14 & 76 \\
\hline 2022 & 3,600 & 0 & 3,600 & 235 & 14 & 76 \\
\hline 2023 & 3,600 & 0 & 3,600 & 248 & 14 & 86 \\
\hline 2024 & 3,600 & 0 & 3,600 & 338 & 14 & 129 \\
\hline 2025 & 3,600 & 0 & 3,600 & 340 & 14 & 130 \\
\hline 2026 & 3,600 & 0 & 3,600 & 323 & 14 & 129 \\
\hline 2027 & 3,600 & 0 & 3,600 & 360 & 14 & 138 \\
\hline 2028 & 3,600 & 0 & 3,600 & 358 & 14 & 143 \\
\hline 2029 & 3,600 & 0 & 3,600 & 370 & 14 & 148 \\
\hline 2030 & 3,600 & 0 & 3,600 & 378 & 15 & 151 \\
\hline 2031 & 3,600 & 0 & 3,600 & 197 & 15 & 186 \\
\hline 2032 & 3,600 & 0 & 3,600 & 0 & 15 & 201 \\
\hline 2033 & 3,600 & 0 & 3,600 & 0 & 15 & 204 \\
\hline 2034 & 3,600 & 0 & 3,600 & 0 & 0 & 191 \\
\hline 2035 & 1,350 & 0 & 1,350 & 0 & 0 & 154 \\
\hline 2036 & 0 & 0 & 0 & 0 & 0 & 66 \\
\hline 2037 & 0 & 0 & 0 & 0 & 0 & 66 \\
\hline 2038 & 0 & 0 & 0 & 0 & 0 & 57 \\
\hline Total & 63,000 & 0 & 63,000 & 4667 & 300 & 2698 \\
\hline
\end{tabular}


Table C-8. Scenario 6 Nominal Receipt, Storage, and Emplacement Rates

\begin{tabular}{|c|c|c|c|c|c|c|}
\hline \multirow[t]{2}{*}{ Year } & \multicolumn{3}{|c|}{ CSNF } & \multicolumn{3}{|c|}{ Receipt/Emplacement Rate } \\
\hline & $\begin{array}{c}\text { Receipt } \\
\text { Rate } \\
\text { (MTHM/yr) }\end{array}$ & $\begin{array}{c}\text { Storage } \\
\text { Rate } \\
\text { (MTHM/yr) }\end{array}$ & $\begin{array}{c}\text { Emplacement } \\
\text { Rate (MTHM/yr) }\end{array}$ & $\begin{array}{c}\text { HLW } \\
\text { (MTHM/yr) }\end{array}$ & $\begin{array}{c}\text { Naval SNF } \\
\text { (Canisters/yr) }\end{array}$ & $\begin{array}{l}\text { Other DSNF } \\
\text { (Canisters/yr) }\end{array}$ \\
\hline 2010 & 200 & 0 & 200 & 20 & 3 & 8 \\
\hline 2011 & 400 & 0 & 400 & 40 & 3 & 16 \\
\hline 2012 & 400 & 0 & 400 & 40 & 6 & 16 \\
\hline 2013 & 400 & 0 & 400 & 40 & 6 & 16 \\
\hline 2014 & 400 & 0 & 400 & 40 & 12 & 16 \\
\hline 2015 & 400 & 0 & 400 & 127.5 & 14 & 18 \\
\hline 2016 & 600 & 0 & 600 & 220 & 14 & 41 \\
\hline 2017 & 1,200 & 0 & 1,200 & 220 & 14 & 62 \\
\hline 2018 & 2,000 & 0 & 2,000 & 220 & 14 & 76 \\
\hline 2019 & 3,000 & 0 & 3,000 & 235 & 14 & 76 \\
\hline 2020 & 3,600 & 0 & 3,600 & 235 & 14 & 76 \\
\hline 2021 & 3,600 & 0 & 3,600 & 220 & 14 & 76 \\
\hline 2022 & 3,600 & 0 & 3,600 & 222.5 & 14 & 76 \\
\hline 2023 & 3,600 & 0 & 3,600 & 215 & 14 & 86 \\
\hline 2024 & 3,600 & 0 & 3,600 & 337.5 & 14 & 129 \\
\hline 2025 & 3,600 & 0 & 3,600 & 340 & 14 & 130 \\
\hline 2026 & 3,600 & 0 & 3,600 & 322.5 & 14 & 129 \\
\hline 2027 & 3,600 & 0 & 3,600 & 360 & 14 & 138 \\
\hline 2028 & 3,600 & 0 & 3,600 & 357.5 & 14 & 143 \\
\hline 2029 & 3,600 & 0 & 3,600 & 370 & 14 & 148 \\
\hline 2030 & 3,600 & 0 & 3,600 & 347.5 & 15 & 151 \\
\hline 2031 & 3,600 & 0 & 3,600 & 137 & 15 & 186 \\
\hline 2032 & 3,600 & 0 & 3,600 & 0 & 15 & 201 \\
\hline 2033 & 3,600 & 0 & 3,600 & 0 & 15 & 204 \\
\hline 2034 & 3,600 & 0 & 3,600 & 0 & 0 & 191 \\
\hline 2035 & 0 & 0 & 0 & 0 & 0 & 154 \\
\hline 2036 & 0 & 0 & 0 & 0 & 0 & 66 \\
\hline 2037 & 0 & 0 & 0 & 0 & 0 & 66 \\
\hline 2038 & 0 & 0 & 0 & 0 & 0 & 3 \\
\hline Total & 63,000 & 0 & 63,000 & 4667 & 300 & 2698 \\
\hline
\end{tabular}


Table C-9. Scenario 7 Nominal Receipt, Storage, and Emplacement Rates

\begin{tabular}{|c|c|c|c|c|c|c|}
\hline \multirow[t]{2}{*}{ Year } & \multicolumn{3}{|c|}{ CSNF } & \multicolumn{3}{|c|}{ Receipt/Emplacement Rate } \\
\hline & $\begin{array}{c}\text { Receipt } \\
\text { Rate } \\
\text { (MTHM/yr) }\end{array}$ & $\begin{array}{c}\text { Storage } \\
\text { Rate } \\
\text { (MTHM/yr) }\end{array}$ & $\begin{array}{c}\text { Emplacement } \\
\text { Rate (MTHM/yr) }\end{array}$ & $\begin{array}{c}\text { HLW } \\
\text { (MTHM/yr) }\end{array}$ & $\begin{array}{c}\text { Naval SNF } \\
\text { (Canisters/yr) }\end{array}$ & $\begin{array}{l}\text { Other DSNF } \\
\text { (Canisters/yr) }\end{array}$ \\
\hline 2010 & 200 & 0 & 200 & 20.0 & 3 & 8 \\
\hline 2011 & 400 & 0 & 400 & 40.0 & 3 & 16 \\
\hline 2012 & 400 & 0 & 400 & 97.5 & 6 & 32 \\
\hline 2013 & 600 & 0 & 600 & 190.0 & 6 & 52 \\
\hline 2014 & 1200 & 0 & 1200 & 190.0 & 12 & 70 \\
\hline 2015 & 2000 & 0 & 2000 & 190.0 & 14 & 82 \\
\hline 2016 & 3000 & 0 & 3000 & 205.0 & 14 & 79 \\
\hline 2017 & 3000 & 0 & 3000 & 205.0 & 14 & 76 \\
\hline 2018 & 3000 & 0 & 3000 & 190.0 & 14 & 76 \\
\hline 2019 & 3000 & 0 & 3000 & 205.0 & 14 & 76 \\
\hline 2020 & 3000 & 0 & 3000 & 215.0 & 14 & 86 \\
\hline 2021 & 3000 & 0 & 3000 & 337.5 & 14 & 129 \\
\hline 2022 & 3000 & 0 & 3000 & 340.0 & 14 & 130 \\
\hline 2023 & 3000 & 0 & 3000 & 322.5 & 14 & 129 \\
\hline 2024 & 3000 & 0 & 3000 & 360.0 & 14 & 138 \\
\hline 2025 & 3000 & 0 & 3000 & 357.5 & 14 & 143 \\
\hline 2026 & 3000 & 0 & 3000 & 370.0 & 14 & 148 \\
\hline 2027 & 3000 & 0 & 3000 & 377.5 & 14 & 151 \\
\hline 2028 & 3000 & 0 & 3000 & 358.0 & 14 & 153 \\
\hline 2029 & 3000 & 0 & 3000 & 96.5 & 14 & 152 \\
\hline 2030 & 3000 & 0 & 3000 & 0 & 15 & 155 \\
\hline 2031 & 3000 & 0 & 3000 & 0 & 15 & 175 \\
\hline 2032 & 3000 & 0 & 3000 & 0 & 15 & 154 \\
\hline 2033 & 3000 & 0 & 3000 & 0 & 15 & 66 \\
\hline 2034 & 3000 & 0 & 3000 & 0 & 0 & 51 \\
\hline 2035 & 1,200 & 0 & 1,200 & 0 & 0 & 49 \\
\hline 2036 & 0 & 0 & 0 & 0 & 0 & 49 \\
\hline 2037 & 0 & 0 & 0 & 0 & 0 & 49 \\
\hline 2038 & 0 & 0 & 0 & 0 & 0 & 24 \\
\hline Total & 63,000 & 0 & 63,000 & 4,667 & 300 & 2,698 \\
\hline
\end{tabular}




\section{C.2 97,800 MTHM WASTE STREAM}

Table C-10. Scenario 1 Nominal CSNF Receipt, Storage, and Emplacement Rates for 97,800 MTHM Waste Stream

\begin{tabular}{|c|c|c|c|}
\hline Year & $\begin{array}{c}\text { Receipt } \\
\text { Rate } \\
\text { (MTHM/yr) }\end{array}$ & $\begin{array}{c}\text { Storage } \\
\text { Rate } \\
\text { (MTHM/yr) }\end{array}$ & $\begin{array}{c}\text { Emplacement } \\
\text { Rate } \\
\text { (MTHM/yr) }\end{array}$ \\
\hline 2010 & 400 & 0 & 400 \\
\hline 2011 & 600 & 0 & 600 \\
\hline 2012 & 1,200 & 0 & 1,200 \\
\hline 2013 & 2,000 & 0 & 2,000 \\
\hline $2014-39$ & 3,000 & 0 & 3,000 \\
\hline 2040 & 1600 & 0 & 1600 \\
\hline Total & 83,800 & 0 & 83,800 \\
\hline
\end{tabular}

Table C-11. Scenario 1, 2, and 4 Nominal Defense Waste Receipt and Emplacement Rates for 97,800 MTHM Waste Stream

\begin{tabular}{|c|c|c|c|}
\hline \multirow[t]{2}{*}{ Year } & HLW & DSNF & Naval SNF \\
\hline & (MTHM/Yr) & (Canisters/Yr) & (Canisters/Yr) \\
\hline 2010 & 97.5 & 18 & 3 \\
\hline 2011 & 190 & 41 & 3 \\
\hline 2012 & 190 & 62 & 6 \\
\hline 2013 & 190 & 76 & 6 \\
\hline 2014 & 205 & 76 & 12 \\
\hline 2015 & 205 & 76 & 14 \\
\hline 2016 & 190 & 76 & 14 \\
\hline 2017 & 205 & 76 & 14 \\
\hline 2018 & 215 & 86 & 14 \\
\hline 2019 & 337.5 & 129 & 14 \\
\hline 2020 & 340 & 130 & 14 \\
\hline 2021 & 322.5 & 129 & 14 \\
\hline 2022 & 360 & 138 & 14 \\
\hline 2023 & 357.5 & 143 & 14 \\
\hline 2024 & 370 & 148 & 14 \\
\hline 2025 & 452.2 & 151 & 14 \\
\hline 2026 & 531.8 & 153 & 14 \\
\hline 2027 & 529.3 & 152 & 14 \\
\hline
\end{tabular}


Table C-11. Scenario 1, 2, and 4 Nominal Defense Waste Receipt and Emplacement Rates for 97,800 MTHM Waste Stream (Continued)

\begin{tabular}{|c|c|c|c|}
\hline \multirow{2}{*}{ Year } & HLW & DSNF & Naval SNF \\
\cline { 2 - 4 } & (MTHM/Yr) & (Canisters/Yr) & (Canisters/Yr) \\
\hline 2028 & 531.8 & 105 & 14 \\
\hline 2029 & 489.8 & 105 & 14 \\
\hline 2030 & 372.5 & 105 & 15 \\
\hline 2031 & 372.5 & 50 & 15 \\
\hline 2032 & 372.5 & 66 & 15 \\
\hline 2033 & 372.5 & 116 & 15 \\
\hline 2034 & 372.5 & 103 & 0 \\
\hline 2035 & 373 & 66 & 0 \\
\hline 2036 & 325 & 49 & 0 \\
\hline 2037 & 310 & 49 & 0 \\
\hline 2038 & 310 & 49 & 0 \\
\hline 2039 & 220.5 & 49 & 0 \\
\hline 2040 & 207.5 & 16 & 0 \\
\hline 2041 & 207.5 & 0 & 0 \\
\hline 2042 & 209 & 0 & 0 \\
\hline Total & 10334.9 & 2788 & 300 \\
\hline & & & \\
\hline
\end{tabular}

Table C-12. Scenario 2 Nominal CSNF Receipt, Storage, and Emplacement Rates for 97,800 MTHM Waste Stream

\begin{tabular}{|c|c|c|c|}
\hline Year & $\begin{array}{c}\text { Receipt } \\
\text { Rate } \\
\text { (MTHM/yr) }\end{array}$ & $\begin{array}{c}\text { Storage } \\
\text { Rate } \\
\text { (MTHM/yr) }\end{array}$ & $\begin{array}{c}\text { Emplacement } \\
\text { Rate } \\
\text { (MTHM/yr) }\end{array}$ \\
\hline 2010 & 400 & 0 & 400 \\
\hline 2011 & 600 & 0 & 600 \\
\hline $2012-19$ & 900 & 0 & 900 \\
\hline 2020 & 1,800 & 0 & 1,800 \\
\hline 2021 & 2,200 & 0 & 2,200 \\
\hline 2022 & 2,600 & 0 & 2,600 \\
\hline 2023 & 3,000 & 0 & 3,000 \\
\hline $2024-41$ & 3,600 & 0 & 3,600 \\
\hline 2042 & 1,200 & 0 & 1,200 \\
\hline Total & 83,800 & 0 & 83,800 \\
\hline
\end{tabular}


Table C-13. Scenario 3 Nominal CSNF Receipt, Storage, and Emplacement Rates for 97,800 MTHM Waste Stream

\begin{tabular}{|c|c|c|c|}
\hline Year & $\begin{array}{c}\text { Receipt } \\
\text { Rate } \\
\text { (MTHM/yr) }\end{array}$ & $\begin{array}{c}\text { Storage } \\
\text { Rate } \\
\text { (MTHM/yr) }\end{array}$ & $\begin{array}{c}\text { Emplacement } \\
\text { Rate } \\
\text { (MTHM/yr) }\end{array}$ \\
\hline 2010 & 400 & 0 & 400 \\
\hline 2011 & 600 & 0 & 600 \\
\hline 2012 & 1,200 & 1,000 & 200 \\
\hline 2013 & 2,000 & 2,000 & 0 \\
\hline $2014-19$ & 3,000 & 3,000 & 0 \\
\hline $2020-39$ & 3,000 & 0 & 3,600 \\
\hline 2040 & 1,600 & 0 & 3,600 \\
\hline 2041 & 0 & 0 & 3,600 \\
\hline 2042 & 0 & 0 & 3,400 \\
\hline Total & 83,800 & 21,000 & 83,800 \\
\hline
\end{tabular}

Table C-14. Scenario 3 Nominal Defense Receipt, Storage, and Emplacement Rates for 97,800 MTHM Waste Stream

\begin{tabular}{|c|c|c|c|c|c|c|c|c|c|}
\hline \multirow[t]{2}{*}{ Year } & \multicolumn{3}{|c|}{ Receipt Rate } & \multicolumn{3}{|c|}{ Storage Rate } & \multicolumn{3}{|c|}{ Emplacement Rate } \\
\hline & $\begin{array}{c}\text { HLW } \\
\text { (MTHM/ } \\
\text { yr) }\end{array}$ & $\begin{array}{c}\text { Naval } \\
\text { SNF } \\
\text { (Can/yr) }\end{array}$ & $\begin{array}{c}\text { DSNF } \\
\text { (Can/yr) }\end{array}$ & $\begin{array}{c}\text { HLW } \\
\text { (MTHM/ } \\
\text { yr) }\end{array}$ & $\begin{array}{c}\text { Naval } \\
\text { SNF } \\
\text { (Can/yr) }\end{array}$ & $\begin{array}{c}\text { DSNF } \\
\text { (Can/yr) }\end{array}$ & $\begin{array}{c}\text { HLW } \\
\text { (MTHM/ } \\
\text { yr) }\end{array}$ & $\begin{array}{c}\text { Naval } \\
\text { SNF } \\
\text { (Can/yr) }\end{array}$ & $\begin{array}{c}\text { DSNF } \\
\text { (Can/yr) }\end{array}$ \\
\hline 2010 & 97.5 & 18 & 3 & 0.0 & 0.0 & 0.0 & 97.5 & 3 & 18 \\
\hline 2011 & 190 & 41 & 3 & 0.0 & 0.0 & 0.0 & 190.0 & 3 & 41 \\
\hline 2012 & 190 & 62 & 6 & 158.3 & 5.0 & 52.0 & 31.7 & 1 & 10 \\
\hline 2013 & 190 & 76 & 6 & 190.0 & 6.0 & 76.0 & 0.0 & 0 & 0 \\
\hline 2014 & 205 & 76 & 12 & 205.0 & 12.0 & 76.0 & 0.0 & 0 & 0 \\
\hline 2015 & 205 & 76 & 14 & 205.0 & 14.0 & 76.0 & 0.0 & 0 & 0 \\
\hline 2016 & 190 & 76 & 14 & 190.0 & 14.0 & 76.0 & 0.0 & 0 & 0 \\
\hline 2017 & 205 & 76 & 14 & 205.0 & 14.0 & 76.0 & 0.0 & 0 & 0 \\
\hline 2018 & 215 & 86 & 14 & 215.0 & 14.0 & 86.0 & 0.0 & 0 & 0 \\
\hline 2019 & 337.5 & 129 & 14 & 337.5 & 14.0 & 129.0 & 0.0 & 0 & 0 \\
\hline 2020 & 340 & 130 & 14 & 0.0 & 0.0 & 0.0 & 408.0 & 17 & 156 \\
\hline 2021 & 322.5 & 129 & 14 & 0.0 & 0.0 & 0.0 & 387.0 & 17 & 155 \\
\hline 2022 & 360 & 138 & 14 & 0.0 & 0.0 & 0.0 & 432.0 & 17 & 166 \\
\hline 2023 & 357.5 & 143 & 14 & 0.0 & 0.0 & 0.0 & 429.0 & 17 & 172 \\
\hline 2024 & 370 & 148 & 14 & 0.0 & 0.0 & 0.0 & 444.0 & 17 & 178 \\
\hline 2025 & 452.2 & 151 & 14 & 0.0 & 0.0 & 0.0 & 542.6 & 17 & 181 \\
\hline
\end{tabular}


Table C-14. Scenario 3 Nominal Defense Receipt, Storage, and Emplacement Rates for 97,800 MTHM Waste Stream (Continued)

\begin{tabular}{|c|c|c|c|c|c|c|c|c|c|}
\hline Year & \multicolumn{3}{|c|}{ Receipt Rate } & \multicolumn{3}{c|}{ Storage Rate } & \multicolumn{3}{c|}{ Emplacement Rate } \\
\cline { 2 - 10 } & $\begin{array}{c}\text { HLW } \\
\text { (MTHM/ } \\
\text { yr) }\end{array}$ & $\begin{array}{c}\text { Naval } \\
\text { SNF } \\
\text { (Can/yr) }\end{array}$ & $\begin{array}{c}\text { DSNF } \\
\text { (Can/yr) }\end{array}$ & $\begin{array}{c}\text { HLW } \\
\text { (MTHM/ } \\
\text { yr) }\end{array}$ & $\begin{array}{c}\text { Naval } \\
\text { SNF } \\
\text { (Can/yr) }\end{array}$ & $\begin{array}{c}\text { DSNF } \\
\text { (Can/yr) }\end{array}$ & $\begin{array}{c}\text { HLW } \\
\text { (MTHM/ } \\
\text { yr) }\end{array}$ & $\begin{array}{c}\text { Naval } \\
\text { SNF } \\
\text { (Can/yr) }\end{array}$ & $\begin{array}{c}\text { DSNF } \\
\text { (Can/yr) }\end{array}$ \\
\hline 2026 & 531.8 & 153 & 14 & 0.0 & 0.0 & 0.0 & 638.2 & 17 & 184 \\
\hline 2027 & 529.3 & 152 & 14 & 0.0 & 0.0 & 0.0 & 635.2 & 17 & 182 \\
\hline 2028 & 531.8 & 105 & 14 & 0.0 & 0.0 & 0.0 & 638.2 & 17 & 126 \\
\hline 2029 & 489.8 & 105 & 14 & 0.0 & 0.0 & 0.0 & 587.8 & 17 & 126 \\
\hline 2030 & 372.5 & 105 & 15 & 0.0 & 0.0 & 0.0 & 447.0 & 18 & 126 \\
\hline 2031 & 372.5 & 50 & 15 & 0.0 & 0.0 & 0.0 & 447.0 & 18 & 60 \\
\hline 2032 & 372.5 & 66 & 15 & 0.0 & 0.0 & 0.0 & 447.0 & 18 & 79 \\
\hline 2033 & 372.5 & 116 & 15 & 0.0 & 0.0 & 0.0 & 447.0 & 18 & 139 \\
\hline 2034 & 372.5 & 103 & 0 & 0.0 & 0.0 & 0.0 & 447.0 & 18 & 124 \\
\hline 2035 & 373 & 66 & 0 & 0.0 & 0.0 & 0.0 & 447.6 & 18 & 79 \\
\hline 2036 & 325 & 49 & 0 & 0.0 & 0.0 & 0.0 & 390.0 & 15 & 59 \\
\hline 2037 & 310 & 49 & 0 & 0.0 & 0.0 & 0.0 & 372.0 & 0 & 59 \\
\hline 2038 & 310 & 49 & 0 & 0.0 & 0.0 & 0.0 & 372.0 & 0 & 59 \\
\hline 2039 & 220.5 & 49 & 0 & 0.0 & 0.0 & 0.0 & 264.6 & 0 & 59 \\
\hline 2040 & 207.5 & 16 & 0 & 0.0 & 0.0 & 0.0 & 249.0 & 0 & 59 \\
\hline 2041 & 207.5 & 0 & 0 & 0.0 & 0.0 & 0.0 & 249.0 & 0 & 59 \\
\hline 2042 & 209 & 0 & 0 & 0.0 & 0.0 & 0.0 & 294.7 & 0 & 132 \\
\hline Total & $10,334.9$ & 300 & 2,788 & $1,705.8$ & 93 & 647 & $10,334.9$ & 300 & 2,788 \\
\hline
\end{tabular}

Table C-15. Scenario 4 Nominal CSNF Receipt, Storage, and Emplacement Rates for 97,800 MTHM Waste Stream

\begin{tabular}{|c|c|c|c|}
\hline Year & $\begin{array}{c}\text { Receipt } \\
\text { Rate } \\
\text { (MTHM/yr) }\end{array}$ & $\begin{array}{c}\text { Storage } \\
\text { Rate } \\
\text { (MTHM/yr) }\end{array}$ & $\begin{array}{c}\text { Emplacement } \\
\text { Rate } \\
\text { (MTHM/yr) }\end{array}$ \\
\hline 2010 & 533 & 0 & 533 \\
\hline 2011 & 800 & 0 & 800 \\
\hline 2012 & 1,600 & 0 & 1,600 \\
\hline 2013 & 2,677 & 0 & 2,677 \\
\hline $2014-32$ & 4,000 & 0 & 4,000 \\
\hline 2033 & 2,190 & 0 & 2,190 \\
\hline Total & 83,800 & 0 & 83,800 \\
\hline
\end{tabular}


Table C-16. Scenario 5 Nominal CSNF and Defense Waste Receipt, Storage, and Emplacement Rates for 97,800 MTHM Waste Stream

\begin{tabular}{|c|c|c|c|c|c|c|}
\hline \multirow[t]{2}{*}{ Year } & \multicolumn{3}{|c|}{ CSNF } & \multicolumn{3}{|c|}{ Receipt/Emplacement Rate } \\
\hline & $\begin{array}{c}\text { Receipt } \\
\text { Rate } \\
\text { (MTHM/yr) }\end{array}$ & $\begin{array}{c}\text { Storage } \\
\text { Rate } \\
\text { (MTHM/yr) }\end{array}$ & $\begin{array}{c}\text { Emplacement } \\
\text { Rate } \\
\text { (MTHM/yr) }\end{array}$ & $\begin{array}{c}\text { HLW } \\
\text { (MTHM/ } \\
\text { yr) }\end{array}$ & $\begin{array}{c}\text { Naval SNF } \\
\text { (Canisters/yr) }\end{array}$ & $\begin{array}{c}\text { Other DSNF } \\
\text { (Canisters/yr) }\end{array}$ \\
\hline 2010 & 50 & 0 & 50 & 10.0 & 3 & 2 \\
\hline 2011 & 100 & 0 & 100 & 20.0 & 3 & 4 \\
\hline 2012 & 100 & 0 & 100 & 20.0 & 6 & 4 \\
\hline 2013 & 100 & 0 & 100 & 20.0 & 6 & 4 \\
\hline 2014 & 100 & 0 & 100 & 20.0 & 12 & 4 \\
\hline 2015 & 400 & 0 & 400 & 97.5 & 14 & 32 \\
\hline 2016 & 600 & 0 & 600 & 190.0 & 14 & 52 \\
\hline 2017 & 1,200 & 0 & 1,200 & 190.0 & 14 & 70 \\
\hline 2018 & 2,000 & 0 & 2,000 & 190.0 & 14 & 82 \\
\hline 2019 & 3,000 & 0 & 3,000 & 205.0 & 14 & 79 \\
\hline 2020 & 3,600 & 0 & 3,600 & 205.0 & 14 & 76 \\
\hline 2021 & 3,600 & 0 & 3,600 & 190.0 & 14 & 76 \\
\hline 2022 & 3,600 & 0 & 3,600 & 205.0 & 14 & 76 \\
\hline 2023 & 3,600 & 0 & 3,600 & 215.0 & 14 & 86 \\
\hline 2024 & 3,600 & 0 & 3,600 & 337.5 & 14 & 129 \\
\hline 2025 & 3,600 & 0 & 3,600 & 340.0 & 14 & 130 \\
\hline 2026 & 3,600 & 0 & 3,600 & 322.5 & 14 & 129 \\
\hline 2027 & 3,600 & 0 & 3,600 & 360.0 & 14 & 138 \\
\hline 2028 & 3,600 & 0 & 3,600 & 357.5 & 14 & 143 \\
\hline 2029 & 3,600 & 0 & 3,600 & 370.0 & 14 & 148 \\
\hline 2030 & 3,600 & 0 & 3,600 & 452.2 & 15 & 151 \\
\hline 2031 & 3,600 & 0 & 3,600 & 531.8 & 15 & 186 \\
\hline 2032 & 3,600 & 0 & 3,600 & 529.3 & 15 & 201 \\
\hline 2033 & 3,600 & 0 & 3,600 & 531.8 & 15 & 204 \\
\hline 2034 & 3,600 & 0 & 3,600 & 489.8 & 0 & 208 \\
\hline 2035 & 3,600 & 0 & 3,600 & 372.5 & 0 & 162 \\
\hline 2036 & 3,600 & 0 & 3,600 & 372.5 & 0 & 49 \\
\hline 2037 & 3,600 & 0 & 3,600 & 372.5 & 0 & 49 \\
\hline 2038 & 3,600 & 0 & 3,600 & 372.5 & 0 & 49 \\
\hline 2039 & 3,600 & 0 & 3,600 & 372.5 & 0 & 49 \\
\hline 2040 & 3,600 & 0 & 3,600 & 373.0 & 0 & 16 \\
\hline 2041 & 550 & 0 & 550 & 373.0 & 0 & 0 \\
\hline
\end{tabular}


Table C-16. Scenario 5 Nominal CSNF and Defense Waste Receipt, Storage, and Emplacement Rates for 97,800 MTHM Waste Stream (Continued)

\begin{tabular}{|c|c|c|c|c|c|c|}
\hline \multirow{2}{*}{ Year } & \multicolumn{3}{|c|}{ CSNF } & \multicolumn{3}{c|}{ Receipt/Emplacement Rate } \\
\cline { 2 - 7 } & $\begin{array}{c}\text { Receipt } \\
\text { Rate } \\
(\text { MTHM/yr) }\end{array}$ & $\begin{array}{c}\text { Storage } \\
\text { Rate } \\
(\text { MTHM/yr) }\end{array}$ & $\begin{array}{c}\text { Emplacement } \\
\text { Rate } \\
\text { (MTHM/yr) }\end{array}$ & $\begin{array}{c}\text { HLW } \\
\text { (MTHM/ } / \\
\text { yr) }\end{array}$ & $\begin{array}{c}\text { Naval SNF } \\
\text { (Canisters/yr) }\end{array}$ & $\begin{array}{c}\text { Other DSNF } \\
\text { (Canisters/yr) }\end{array}$ \\
\hline 2042 & 0 & 0 & 0 & 373.0 & 0 & 0 \\
\hline 2043 & 0 & 0 & 0 & 373.0 & 0 & 0 \\
\hline 2044 & 0 & 0 & 0 & 373.0 & 0 & 0 \\
\hline 2045 & 0 & 0 & 0 & 207.5 & 0 & 0 \\
\hline Total & 83,800 & 0 & 83,800 & $10,334.9$ & 300 & 2788 \\
\hline
\end{tabular}

Table C-17. Scenario 6 Nominal CSNF and Defense Waste Receipt, Storage, and Emplacement Rates for 97,800 MTHM Waste

\begin{tabular}{|c|c|c|c|c|c|c|}
\hline \multirow[t]{2}{*}{ Year } & \multicolumn{3}{|c|}{ CSNF } & \multicolumn{3}{|c|}{ Receipt/Emplacement Rate } \\
\hline & \begin{tabular}{|c|} 
Receipt \\
Rate \\
(MTHMr)
\end{tabular} & $\begin{array}{c}\begin{array}{c}\text { Storage } \\
\text { Rate } \\
\text { (MTHM/yr) }\end{array} \\
\end{array}$ & $\begin{array}{c}\text { Emplacement Rate } \\
\text { (MTHMyr) }\end{array}$ & $\begin{array}{c}\text { HLW } \\
\text { (MTHM/yr) }\end{array}$ & $\begin{array}{c}\text { Naval SNF } \\
\text { (Canisters/yr) }\end{array}$ & $\begin{array}{c}\text { Other DSNF } \\
\text { (Canisters/yr) }\end{array}$ \\
\hline 2010 & 200 & 0 & 200 & 20.0 & 3 & 8 \\
\hline 2011 & 400 & 0 & 400 & 40.0 & 3 & 16 \\
\hline 2012 & 400 & 0 & 400 & 40.0 & 6 & 16 \\
\hline 2013 & 400 & 0 & 400 & 40.0 & 6 & 16 \\
\hline 2014 & 400 & 0 & 400 & 40.0 & 12 & 16 \\
\hline 2015 & 400 & 0 & 400 & 97.5 & 14 & 32 \\
\hline 2016 & 600 & 0 & 600 & 190.0 & 14 & 52 \\
\hline 2017 & 1,200 & 0 & 1,200 & 190.0 & 14 & 70 \\
\hline 2018 & 2,000 & 0 & 2,000 & 190.0 & 14 & 82 \\
\hline 2019 & 3,000 & 0 & 3,000 & 205.0 & 14 & 79 \\
\hline 2020 & 3,600 & 0 & 3,600 & 205.0 & 14 & 76 \\
\hline 2021 & 3,600 & 0 & 3,600 & 190.0 & 14 & 76 \\
\hline 2022 & 3,600 & 0 & 3,600 & 205.0 & 14 & 76 \\
\hline 2023 & 3,600 & 0 & 3,600 & 215.0 & 14 & 86 \\
\hline 2024 & 3,600 & 0 & 3,600 & 337.5 & 14 & 129 \\
\hline 2025 & 3,600 & 0 & 3,600 & 340.0 & 14 & 130 \\
\hline 2026 & 3,600 & 0 & 3,600 & 322.5 & 14 & 129 \\
\hline 2027 & 3,600 & 0 & 3,600 & 360.0 & 14 & 138 \\
\hline 2028 & 3,600 & 0 & 3,600 & 357.5 & 14 & 143 \\
\hline 2029 & 3,600 & 0 & 3,600 & 370.0 & 14 & 148 \\
\hline
\end{tabular}


Table C-17. Scenario 6 Nominal CSNF and Defense Waste Receipt, Storage, and Emplacement Rates for 97,800 MTHM Waste (Continued)

\begin{tabular}{|c|c|c|c|c|c|c|}
\hline \multirow[t]{2}{*}{ Year } & \multicolumn{3}{|c|}{ CSNF } & \multicolumn{3}{|c|}{ Receipt/Emplacement Rate } \\
\hline & $\begin{array}{c}\text { Receipt } \\
\text { Rate } \\
\text { (MTHM/yr) }\end{array}$ & $\begin{array}{c}\text { Storage } \\
\text { Rate } \\
\text { (MTHM/yr) }\end{array}$ & $\begin{array}{c}\text { Emplacement Rate } \\
\text { (MTHM/yr) }\end{array}$ & $\begin{array}{c}\text { HLW } \\
\text { (MTHM/yr) }\end{array}$ & $\begin{array}{l}\text { Naval SNF } \\
\text { (Canisters/yr) }\end{array}$ & $\begin{array}{c}\text { Other DSNF } \\
\text { (Canisters/yr) }\end{array}$ \\
\hline 2030 & 3,600 & 0 & 3,600 & 452.2 & 15 & 151 \\
\hline 2031 & 3,600 & 0 & 3,600 & 531.8 & 15 & 186 \\
\hline 2032 & 3,600 & 0 & 3,600 & 529.3 & 15 & 201 \\
\hline 2033 & 3,600 & 0 & 3,600 & 531.8 & 15 & 204 \\
\hline 2034 & 3,600 & 0 & 3,600 & 489.8 & 0 & 179 \\
\hline 2035 & 3,600 & 0 & 3,600 & 372.5 & 0 & 137 \\
\hline 2036 & 3,600 & 0 & 3,600 & 372.5 & 0 & 49 \\
\hline 2037 & 3,600 & 0 & 3,600 & 372.5 & 0 & 49 \\
\hline 2038 & 3,600 & 0 & 3,600 & 372.5 & 0 & 49 \\
\hline 2039 & 3,600 & 0 & 3,600 & 372.5 & 0 & 49 \\
\hline 2040 & 2,800 & 0 & 2800 & 373.0 & 0 & 16 \\
\hline 2041 & 0 & 0 & 0 & 373.0 & 0 & 0 \\
\hline 2042 & 0 & 0 & 0 & 373.0 & 0 & 0 \\
\hline 2043 & 0 & 0 & 0 & 373.0 & 0 & 0 \\
\hline 2044 & 0 & 0 & 0 & 373.0 & 0 & 0 \\
\hline 2045 & 0 & 0 & 0 & 117.5 & 0 & 0 \\
\hline Total & 83,800 & 0 & 83,800 & 10334.9 & 300 & 2788 \\
\hline
\end{tabular}

Table C-18. Scenario 7 Nominal CSNF and Defense Waste Receipt, Storage, and Emplacement Rates for 97,800 MTHM Waste Stream

\begin{tabular}{|c|c|c|c|c|c|c|}
\hline \multirow{2}{*}{ Year } & \multicolumn{3}{|c|}{ CSNF } & \multicolumn{3}{c|}{ Receipt/Emplacement Rate } \\
\cline { 2 - 7 } & $\begin{array}{c}\text { Receipt } \\
\text { Rate } \\
\text { (MTHM/yr) }\end{array}$ & $\begin{array}{c}\text { Storage } \\
\text { Rate } \\
\text { (MTHM/yr) }\end{array}$ & $\begin{array}{c}\text { Emplacement } \\
\text { Rate } \\
\text { (MTHM/yr) }\end{array}$ & $\begin{array}{c}\text { HLW } \\
\text { (MTHM/yr) }\end{array}$ & $\begin{array}{c}\text { Naval SNF } \\
\text { (Canisters/yr) }\end{array}$ & $\begin{array}{c}\text { Other DSNF } \\
\text { (Canisters/yr) }\end{array}$ \\
\hline 2010 & 200 & 0 & 200 & 20.0 & 3 & 8 \\
\hline 2011 & 400 & 0 & 400 & 40.0 & 3 & 16 \\
\hline 2012 & 400 & 0 & 400 & 97.5 & 6 & 18 \\
\hline 2013 & 600 & 0 & 600 & 190.0 & 6 & 41 \\
\hline 2014 & 1200 & 0 & 1200 & 190.0 & 12 & 62 \\
\hline 2015 & 2000 & 0 & 2000 & 190.0 & 14 & 76 \\
\hline 2016 & 3000 & 0 & 3000 & 205.0 & 14 & 76 \\
\hline
\end{tabular}


Table C-18. Scenario 7 Nominal CSNF and Defense Waste Receipt, Storage, and Emplacement Rates for 97,800 MTHM Waste Stream (Continued)

\begin{tabular}{|c|c|c|c|c|c|c|}
\hline \multirow[t]{2}{*}{ Year } & \multicolumn{3}{|c|}{ CSNF } & \multicolumn{3}{|c|}{ Receipt/Emplacement Rate } \\
\hline & $\begin{array}{c}\text { Receipt } \\
\text { Rate } \\
\text { (MTHM/yr) }\end{array}$ & $\begin{array}{c}\text { Storage } \\
\text { Rate } \\
\text { (MTHM/yr) }\end{array}$ & $\begin{array}{c}\text { Emplacement } \\
\text { Rate } \\
\text { (MTHM/yr) }\end{array}$ & $\begin{array}{c}\text { HLW } \\
\text { (MTHM/yr) }\end{array}$ & $\begin{array}{c}\text { Naval SNF } \\
\text { (Canisters/yr) }\end{array}$ & $\begin{array}{c}\text { Other DSNF } \\
\text { (Canisters/yr) }\end{array}$ \\
\hline 2017 & 3000 & 0 & 3000 & 205.0 & 14 & 76 \\
\hline 2018 & 3000 & 0 & 3000 & 190.0 & 14 & 76 \\
\hline 2019 & 3000 & 0 & 3000 & 205.0 & 14 & 76 \\
\hline 2020 & 3000 & 0 & 3000 & 215.0 & 14 & 86 \\
\hline 2021 & 3000 & 0 & 3000 & 337.5 & 14 & 129 \\
\hline 2022 & 3000 & 0 & 3000 & 340.0 & 14 & 130 \\
\hline 2023 & 3000 & 0 & 3000 & 322.5 & 14 & 129 \\
\hline 2024 & 3000 & 0 & 3000 & 360.0 & 14 & 138 \\
\hline 2025 & 3000 & 0 & 3000 & 357.5 & 14 & 143 \\
\hline 2026 & 3000 & 0 & 3000 & 370.0 & 14 & 148 \\
\hline 2027 & 3000 & 0 & 3000 & 452.2 & 14 & 151 \\
\hline 2028 & 3000 & 0 & 3000 & 531.8 & 14 & 153 \\
\hline 2029 & 3000 & 0 & 3000 & 529.3 & 14 & 152 \\
\hline 2030 & 3000 & 0 & 3000 & 531.8 & 15 & 155 \\
\hline 2031 & 3000 & 0 & 3000 & 489.8 & 15 & 175 \\
\hline 2032 & 3000 & 0 & 3000 & 372.5 & 15 & 154 \\
\hline 2033 & 3000 & 0 & 3000 & 372.5 & 15 & 66 \\
\hline 2034 & 3000 & 0 & 3000 & 372.5 & 0 & 51 \\
\hline 2035 & 3000 & 0 & 3000 & 372.5 & 0 & 49 \\
\hline 2036 & 3000 & 0 & 3000 & 372.5 & 0 & 49 \\
\hline 2037 & 3000 & 0 & 3000 & 373.0 & 0 & 49 \\
\hline 2038 & 3000 & 0 & 3000 & 373.0 & 0 & 49 \\
\hline 2039 & 3000 & 0 & 3000 & 373.0 & 0 & 49 \\
\hline 2040 & 3000 & 0 & 3000 & 373.0 & 0 & 16 \\
\hline 2041 & 3000 & 0 & 3000 & 373.0 & 0 & 0 \\
\hline 2042 & 1000 & 0 & 1000 & 237.5 & 0 & 0 \\
\hline Total & 83800 & 0 & 83800 & 10334.9 & 300.0 & 2788.0 \\
\hline
\end{tabular}


INTENTIONALLY LEFT BLANK 
INTENTIONALLY LEFT BLANK 


\section{APPENDIX D - SUMMARY SYSTEM COST WORKSHEETS}

The worksheet files listed below contain the summary cost calculations for the 70,000 MTHM and 97,800 MTHM waste streams. These files are included electronically on a compact disk.

\begin{tabular}{|l|c|c|}
\hline \multicolumn{1}{|c|}{ File Name } & Size (kB) & Date \\
\hline Design-Alt_Summary-Case1 Rev 0.xls & 2,397 & $8 / 8 / 02$ \\
\hline Design-Alt_Summary-Case2 Rev 0.xls & 2,374 & $8 / 8 / 02$ \\
\hline Design-Alt_Summary-Case3A Rev 0.xls & 2,384 & $8 / 8 / 02$ \\
\hline Design-Alt_Summary-Case4 Rev 0.xls & 2,384 & $8 / 8 / 02$ \\
\hline Design-Alt_Summary-Case5 Rev 0.xls & 2,444 & $8 / 8 / 02$ \\
\hline Design-Alt_Summary-Case6 Rev 0.xls & 2,368 & $8 / 8 / 02$ \\
\hline Design-Alt_Summary-Case7 Rev 0.xls & 2,404 & $8 / 8 / 02$ \\
\hline Subsurface Construction Rev 0.xls & 108 & $8 / 2 / 02$ \\
\hline Surface Facilities Detail By Phase Rev 0.xls & 33 & $8 / 8 / 02$ \\
\hline Cost Results Summary Rev 0.xls & 231 & $8 / 8 / 02$ \\
\hline
\end{tabular}


INTENTIONALLY LEFT BLANK 
APPENDIX E

ANALYSIS OF STATUTORY AND REGULATORY FLEXIBILITY

TO ACCOMMODATE A PHASED APPROACH TO REPOSITORY DEVELOPMENT 
INTENTIONALLY LEFT BLANK 


\section{APPENDIX E - ANALYSIS OF STATUTORY AND REGULATORY FLEXIBILITY TO ACCOMMODATE A PHASED APPROACH TO REPOSITORY DEVELOPMENT}

Purpose and Assumptions: This analysis addresses questions about the Department of Energy's (DOE's) statutory authority to adopt a phased approach to development of a licensed repository, and the Nuclear Regulatory Commission's (NRC's) administrative discretion to license it.

The purpose of phased repository construction and waste emplacement is assumed here to be to allow DOE, after receiving the required NRC approvals for construction and operation of a fullscale repository, to begin repository operation on a limited scale more quickly than currently contemplated, so that the Department can begin acquiring confirmatory data on pre-closure operations and post-closure compliance as quickly as practicable. This first phase could, for example, be a pilot-scale emplacement of radioactive wastes after appropriately limited underground construction. This would allow an early start on work to confirm the technical bases for the thermal emplacement mode approved in the license. If the initial approved mode were low temperature, the initial phase of repository operation could also provide data to support a license amendment for higher temperature operation by emplacing test quantities of wastes in a high temperature configuration.

Once the initial phase complies with applicable license conditions and specifications, it is assumed to be followed by a step-wise sequence of limited expansions of surface and underground facilities to permit additional underground emplacements under continuing DOE evaluation and NRC oversight. As operational conditions change and NRC permits (e.g., through approval of a license amendment, if necessary), these subsequent emplacements might take place with progressively higher-temperature wastes, or with wastes thermally similar to those initially emplaced but at different rates or spatial densities to produce different peak temperatures in the ambient host rock.

\section{Does any provision of the Nuclear Waste Policy Act (NWPA), as amended, prohibit DOE from adopting such a phased approach?}

No. The Act specifies limits only on the phasing of facility development for the Program as a whole, not for the phasing of repository operations area development at Yucca Mountain. Section $114(d)$, for example, prohibits the emplacement of more than 70,000 metric tons of heavy metal (MTHM) of spent fuel or the high-level waste derived from reprocessing an equivalent amount of this material until a second repository begins operation. Section 148(d)(1) of the Act also stipulates that the construction of any monitored retrievable storage (MRS) facility "may not begin until the Commission has issued a license for the construction of a repository." In addition, section 141(g) prohibits MRS construction in any State with a site approved for site characterization, and further specifies that this restriction "shall continue to apply to any site selected for construction as a repository."

Section 141(g) might be interpreted by some as a constraint on the development of more surface storage capacity at Yucca Mountain than would be needed to support planned waste emplacement 
operations under a phased approach to building and operating a licensed repository. But such a case would have to show that DOE's plans for surface storage as an integral part of a Yucca Mountain repository effectively amount to the development of an MRS. As discussed under Question 2 below, DOE can take prudent measures to manage the phasing of surface and underground components of the repository operations area to make such a case exceedingly difficult.

More important, a close reading of the Act does not support any apparent Congressional intention to constrain the development of pre-emplacement surface storage facilities at a repository site. Subsection 141(g) only forbids construction of an MRS facility "developed pursuant to this section" in Nevada. Expanded lag storage that is an integral part of the surface facilities of a repository is not an MRS developed pursuant to Section 141. Further, the Act does not explicitly define "storage" or "MRS" at all, much less in a way that could be applied to storage at a repository. Thus, there does not appear to be much statutory basis for an objection that lag storage at a repository as an integral part of repository operation is an MRS prohibited by section 141.

Further, as long as Yucca Mountain is being developed as a repository, there can be no question of an inconsistency with the spirit of the Act's prohibition of an MRS in Nevada if the total amount of storage at the repository were limited to the amount of SNF and waste licensed for disposal there. Section 114(d) makes it clear that the intent of the Act is to prohibit imposing more than 70,000 MTHM of waste on any one small area of the country until a second repository is in operation. The last sentence of that subsection specifies that if an MRS is located, or planned to be located, within 50 miles of the first repository,

"the Commission decision approving the first [repository] application shall prohibit the emplacement of a quantity of spent fuel containing in excess of 70,000 metric tons of heavy metal or a quantity of solidified high-level radioactive waste resulting from the reprocessing of spent fuel in both the repository and monitored retrievable storage facility until such time as a second repository is in operation."

The prohibitions here apply specifically only to emplacement of wastes in an MRS and in the first repository, not to the storage of wastes at the repository to facilitate their emplacement. However, it is clear that temporary surface storage at the repository for up to the total amount approved for disposal in a repository (limited by law to 70,000 MTHM in the initial license) would not violate the intent of these restrictions on an MRS facility in the vicinity of a repository.

A plain reading of all these provisions of the Act suggests that Congress intended to phase the development of the MRS and the first repository only to assure that the Program as a whole remained committed to the ultimate goal of providing safe and sufficient geologic disposal capacity for all the nation's spent fuel and HLW. So long as this commitment remains clear and credible, nothing in the Act would prohibit the phasing of facility construction and waste emplacement operations at Yucca Mountain in a way that would allow some waste received at the repository to be stored for a period before emplacement underground. 
Prudence would counsel DOE to propose in its initial license application that NRC authorize construction of a disposal facility that could ultimately accommodate the statutory maximum 70,000 metric tons of waste allowed without a second repository. But the law does not require the Commission to reject a DOE application for less. To the contrary, Section 114(d) of the NWPA as amended specifically provides for NRC review of an application to construct only a part of the repository:

"The Commission shall consider an application for a construction authorization for all or part of a repository in accordance with the laws applicable to such applications." [emphasis added]

The legislative history of this provision documents a clear Congressional intent that the Commission consider a DOE application to construct a repository that is smaller than the maximum allowed. Congress enacted the provision in spite of the fact that the Commission at the time did not support it. In comments submitted on the first comprehensive nuclear waste bill containing this language (H.R. 5016, $97^{\text {th }}$ Congress), the Nuclear Regulatory raised a concern about the bill's requirement to consider an application to license part of a repository:

"We believe that the provision in Section 8(d) requiring the Commission to consider a license application for part of a repository is ill advised. The Commission believes it presently has authority under the Atomic Energy Act, as amended, to establish requirements for a license application, and we have the discretionary authority to set requirements to cover part or all of a repository. However, in this first-of-a-kind undertaking, we do not think it prudent to legislate this restrictive requirement in advance. We would prefer to look at a complete application from DOE for the entire repository in order to properly evaluate geologic and hydrologic conditions at the site for any potential health and safety problems before issuing a license to emplace waste in all or part of the repository." (Letter from Nunzio J. Palladino, Chairman, NRC, to the Honorable Hamilton Fish, Committee on Science and Technology, U.S. House of Representatives, December 11, 1981. Contained in the House Report on the High-Level Radioactive Waste Management and Policy Act (H.R. 5016), December 15, 1981, Rept. 97-411 Part 1.)

Note that the Commission was objecting here only to a legislative requirement that NRC consider an application for part of a repository, not to such consideration per se; the Commission argued that it already has the discretion for such consideration under existing law. Note also that the source of the objection appears to be the Commission's preference to see an application covering the entire underground part of the repository, so that the whole geologic disposal system can be evaluated before approving any emplacement. In any case, Congress proceeded to adopt the "all or part of" language despite the Commission's view. The language remained in H.R. 5016 as reported by the Committee on Science and Technology, was incorporated into a consolidated House nuclear waste bill, and was ultimately enacted in Section 114(d) of the NWPA. 


\section{Do any provisions of NRC's 10 CFR Part 63 repository licensing rule prohibit or otherwise constrain DOE from adopting the phased development approach described above?}

There is no clear regulatory bar to the phased implementation of repository development. NRC staff has in fact specifically said just the opposite. Commenting on "Proposed Alternative Strategy for the Department of Energy's Civilian Radioactive Waste Management Program," a 1993 DOE task force report, NRC wrote: "The staff believes that the concept of phased emplacement is permitted under 10 CFR 60." (Robert M. Bernero, Director, Office of Nuclear Material Safety and Safeguards, USNRC, letter to Christopher Kouts, Acting Director, Strategic Planning and International Programs, OCRWM, September 14, 1993, p. 3.) If NRC believed that phased repository development is permitted under Part 60 , it is difficult to imagine that phased development would not also be permitted under Part 63, a rule predicated on risk-informed, performance-based regulation.

The only provision of the Part 63 rule that could constrain the implementation of phased repository development is the requirement that underground facility construction be "substantially complete" before NRC may issue a license for DOE to receive and possess waste at the repository. But as a closer reading of this requirement in the context of other NRC requirements will show, even the pre-requisite of "substantially complete" construction is best construed in a way that would permit phased repository construction and phased waste emplacement.

Consistent with the accepted Congressional intent of Section 114(d), the rule does not specify a minimum quantity of spent fuel or high level waste for which the Commission could accept an application to construct a repository. Section 63.42 (d) of the rule would simply implement with a universal license condition the law's requirement to phase the development of the first repository to promote development of a second:

"A license issued under this part includes the provisions set forth in Section 114(d) of the Nuclear Waste Policy Act, as amended, defining the quantity of solidified high-level radioactive waste and spent nuclear fuel, until such time as a second repository is in operation, whether or not these provisions are expressly set forth in the license."

The rule not only does not prohibit DOE from applying to construct a portion of the repository's statutory maximum capacity. It also provides for construction, waste receipt, and waste emplacement schedules that may, within the limits of applicable law and regulation, be somewhat independent of each other. Sec. 63.21(b)(2) on the content of any license application specifically provides that the application include "[p]roposed schedules for construction, receipt of waste, and emplacement of wastes at the proposed geologic repository operations area."

Thus, regardless of the amount of wastes DOE might propose to emplace in any license application, schedules for repository construction and waste receipt and emplacement are implicitly issues for separate consideration in a license review. Whether DOE applies for a license to construct a repository capable of emplacing the full initial 70,000 MHTM waste inventory allowed by law or something less, the schedule for construction of that capacity would 
remain an issue for separate adjudication, as would the schedules for receipt and emplacement of that inventory.

Part 63 can therefore be presumed to envision the staging of these activities, especially for the purpose of optimizing the safety of repository construction and operation. The start of surface storage facility construction need not await the completion of underground facility construction, for example, nor is DOE required to complete all surface handling and storage facilities before beginning to receive wastes.

Considering the fundamental interdependence of these activities, however, the rule's allowance for NRC consideration of an application to construct only part of a repository does not mean that DOE should expect to put off a review of its plans for the remainder. NRC's comments on the 1981 nuclear waste bill show that it would be concerned about an application for "part of a repository" if DOE did not also explain in detail its plans for eventual development of the entire repository system. It would be difficult for $\mathrm{NRC}$, or any regulator, to determine the conditions needed for safe operation of only one segment of the system without a clear understanding of how that segment would affect the safety of the rest of the system.

It is clear from the regulations that NRC could, if it chose, place conditions on the license limiting the amount that could initially be emplaced. Given the Commission's concerns about the need to review the proposed repository system as a whole, DOE would probably be wise to apply for NRC authorization to build a repository for the full 70,000 MHTM inventory allowed under current law. The application would present the necessary plans, schedules, procedures, and justification for the Department's preferred phasing of capacity development for this inventory. The Commission would then have discretion to impose any other conditions it deemed necessary to control or coordinate the development of facilities for receiving, handling, packaging, storing, and emplacing this quantity of wastes.

As discussed under Question 1 above, the NWPA does provide procedural assurances against the possibility that indefinite long-term storage capacity might be developed at the expense of repository development. But DOE compliance with these statutory restrictions need not interfere with phased development of a repository as long as there is a clear and reasonable relationship between DOE's proposed plans for emplacement and its proposed plans for interim surface storage.

Once DOE submits an application for authorization to construct an underground facility for emplacement, the burden would arguably be on those who would contend that the surface facilities supporting emplacement would effectively constitute an MRS within the meaning of NWPA section 141(g). Prudent proposals in DOE's initial license application could limit the salience of any such claim. First, as noted above, DOE would be well-advised to apply at the outset for conditional authority to construct, in defined phases under NRC oversight, a repository with an ultimate capacity of 70,000 metric tons pending the availability of a second repository. Second, DOE could propose to sequence the construction of surface storage so that it could not exceed a stipulated ratio of storage to emplacement capacity during the first phase of repository construction. This ratio could be adjusted in subsequent phases to provide for proportionally more surface storage capacity with each new increment of disposal capacity, if ongoing 
evaluations of excavation data confirmed that expanded emplacement could proceed safely and in compliance with long-term performance requirements.

Coordinated build-out of surface and underground facilities can allow for improvements of the system based on experience. While one might not expect to learn much from the construction of surface handling facilities, for example, one could learn quite a bit about the adequacy of the design and ways to improve it during the initial stages of operation. Just as for the underground facilities, one can argue that construction of the surface facilities in stages would allow a shakedown and optimization of waste receipt, handling, and packaging facilities at each stage before construction of subsequent stages. Phasing the scale-up of surface facilities and operations could also provide opportunities for improvements underground. To the extent that it could accommodate lessons learned from excavations for emplacement, staged surface facility development could, for example, permit adjustments in waste package design, construction, loading, or sealing that might enhance confidence in post-closure performance.

Within some rule of reason linking rates of waste acceptance to rates of underground emplacement, the Section 63.21(b)(2) requirement for separate schedules effectively gives the Department the discretion to propose (and the Commission the discretion to require) different initial phasing and independent later adjustment of the schedule for each activity.

To enhance flexibility for these kinds of adjustments, one way to interpret the language permitting an application for "part of a repository" could be to include, with the proposed underground facility design, detailed designs only for the initial surface facilities. This would allow the design of facilities for subsequent operational stages to be deferred until they can be based on actual operating experience supporting underground emplacement. In this approach, the application would present the postclosure safety case for the entire projected disposal inventory, but would focus the application for the surface facilities on the initial stage. The logic would be that because there is little question about DOE's ability to design and ultimately license full-scale surface facilities for waste receipt, handling, packaging, and storage, it is not necessary to prove that point before starting surface operations at small scale. Furthermore, it might be prudent to defer detailed design of large-scale disposal packaging equipment and facilities until the waste package design has been approved in the initial construction authorization, and until DOE has been able to evaluate the cost-effectiveness of potential design refinements based on initial operating experience and further research.

Whatever DOE's rationale for its implementation choices in the initial license application, it is important to keep in mind that flexibility for staged waste receipt, repository construction, and waste emplacement is consistent with the Commission's risk-informed, performance-based (RIPB) approach to the development of the technical criteria for licensing Yucca Mountain. In its rule, the Commission said it sought to "establish a coherent body of risk-informed, performancebased criteria for Yucca Mountain that is compatible with the Commission's overall 
philosophy of risk-informed, performance-based regulation." It then defined this philosophy as:

"an approach in which risk insights, engineering analysis and judgment (e.g., defense in depth), and performance history are used to (1) focus attention on the most important activities, (2) establish objective criteria for evaluating performance, (3) develop measurable or calculable parameters for monitoring system and licensee performance, (4) provide flexibility to determine how to meet the established performance criteria in a way that will encourage and reward improved outcomes, and (5) focus on the results as the primary basis for regulatory decision-making." (Federal Register, Volume 64, Number 34 [February 22, 1999], page 8643)

Given such priorities as developing "measurable or calculable parameters for monitoring system performance," providing flexibility to adjust compliance strategies to "encourage and reward improved outcomes," and focusing on "results as the primary basis for regulatory decisionmaking," it is difficult to see how NRC's risk-informed, performance-based approach could be implemented without a phased implementation schedule. With this first-of-a-kind facility, there can be no "results" for NRC's regulatory decision making after construction authorization if there is no phased construction and operation to permit additional data gathering and evaluation before expanding to the next phase.

The Commission's provision for continuing evaluation of lessons learned from construction and operation is even more explicit in Section 63.21's requirement for a discussion of confirmatory research and development in the LA. Under paragraph (21), the SAR must include:

"An identification of those structures, systems, and components of the geologic repository, both surface and subsurface, which require research and development to confirm the adequacy of design. For structures, systems, and components important to safety and for the engineered and natural barriers important to waste isolation, DOE shall provide a detailed description of the Programs designed to resolve safety questions, including a schedule indicating when these questions would be resolved."

With its requirement for a schedule for the resolution of safety questions needing confirmatory research, this paragraph arguably presumes that the Commission's authorization of construction will be contingent on the results of further information gathering. The rule's section on CA conditions also makes this clear. Section 63.32(b) binds the Commission itself to issue the construction authorization with conditions and reporting requirements, in order to provide timely notice of developments that could affect continuing compliance with those conditions:

"The Commission will incorporate, in the construction authorization, provisions requiring DOE to furnish periodic or special reports regarding:

(1) Progress of construction; 
(2) Any data about the site, obtained during construction, that are not within the predicted limits on which the facility design was based;

(3) Any deficiencies, in design and construction, that, if uncorrected, could adversely affect safety at any future time; and

(4) Results of research and development programs being conducted to resolve safety questions."

Subsection (c) of section 63.32 also provides for Commission control over changes in repository design, construction, and implementation procedures approved in the initial construction authorization:

"The construction authorization for a geologic repository operations area at the Yucca Mountain site will include restrictions on subsequent changes to the features of the geologic repository and the procedures authorized. The restrictions that may be imposed under this paragraph can include measures to prevent adverse effects on the geologic setting as well as measures related to the design and construction of the geologic repository operations area."

The Commission reserved authority to impose functionally similar conditions and controls over its issuance of a license to receive and possess (LTRP) radioactive waste for emplacement. Section 63.43(a) on license specifications provides that:

"A license issued under this part shall include license conditions derived from the analyses and evaluations included in the application, including amendments made before a license is issued, together with such additional conditions as the Commission finds appropriate."

Note here that conditions on receipt and possession for emplacement are to be derived not only from the analyses and evaluations provided in the license application. They may also derive from DOE "amendments" to the application "made before a license is issued." Because, as will be discussed shortly below, DOE may not even apply for the possession license until after NRC issuance of the construction authorization, the Commission clearly anticipated here that conditions for the license for waste emplacement would build on lessons learned from analyses and evaluations conducted during construction.

As this subsection also makes clear, however, conditions on the license could derive from lessons learned even after DOE's submittal of its initial application to receive and possess wastes for emplacement. The Commission reserves the right here to impose "such additional conditions as [it] finds appropriate" -- including, presumably, those justified by new data and analyses not only from prior construction, but also, after Commission issuance of the initial LTRP, from prior emplacements. 
The kinds of license conditions specifically defined in the rule also suggest that the Commission had something very like a phased approach to repository implementation in mind. Subsection 63.43(b) says that license conditions "shall include items in the following categories:

...Restrictions as to the amount of waste permitted per unit volume of storage space, considering the physical characteristics of both the waste and the host rock.

Requirements relating to test, calibration, or inspection, to assure that the foregoing restrictions are observed."

These are just the sort of parameters that any pilot-scale waste emplacement operation, and subsequent phases of expanded emplacement, would seek to analyze and evaluate.

The continuing evaluation of Commission-approved licensing conditions against the actual conditions encountered during construction and operation is in fact a key element of the agency's entire approach to repository regulation. Subpart F of Part 63, like Subpart F of the original Part 60 before it, requires DOE to conduct a performance confirmation program from the outset of site characterization to the end of license termination proceedings. The purpose is to "verify the assumptions, data, and analyses that ... permitted construction of the repository." Proposed Section 63.132, for example, requires that:

"During repository construction and operation, a continuing program of surveillance, measurement, testing, and geologic mapping shall be conducted to ensure that geotechnical and design parameters are confirmed and to ensure that appropriate action is taken to inform the Commission of changes needed in design to accommodate actual field conditions encountered. ... If significant differences exist between the measurements and observations and the original design bases and assumptions, the need for modifications to the design or in construction methods shall be determined and these differences, their significance to repository performance, and the recommended changes reported to the Commission."

To test the approved repository design in time to permit such changes as soon as possible, Section 63.133 of the rule further requires the emplacement of waste packages "as early as practicable" in the "early or developmental stages of construction":

“(a) During the early or developmental stages of construction, a program for in-situ testing of such features as ... the thermal interaction effects of the waste packages, backfill, rock, and groundwater shall be conducted.

(b) The testing shall be initiated as early as practicable."

Considering that the emplacement of waste packages containing radioactive materials would probably provide more realistic if not more useful data for evaluating repository design, it would be consistent with the intent of this requirement for DOE to apply for a license to receive and possess the needed quantity of wastes as soon as construction of enough of the underground facility has been completed for the safe initiation of testing. Even if that portion of the facility is 
very small - and a truly risk-informed, performance-based approach would dictate that it be no larger than necessary to produce the needed safety information as soon as possible -- Section 63.133 could reasonably be construed as requiring the completion of such an area as a first priority for the initiation of waste package testing under radiologically hot operating conditions "as early as practicable."

It should also be clear that with performance confirmation and other requirements for continuing safety evaluations and risk-informed readjustments, a phased approach to repository construction and operation would be compatible with an initial license for either hot or cool operation. In either case, testing would be required during initial operations to demonstrate or confirm the acceptability of the preferred thermal mode. But even if the initial license were for operation at a cooler temperature, DOE would likely want to perform the tests needed to support a subsequent application to amend the license for hotter operation. Preclosure considerations, such as a shorter operating period to minimize cumulative exposures from surface facilities, favor higher temperature repository operation, so that if postclosure uncertainties can be favorably resolved, there would be an incentive to switch to a hotter mode.

Even if the initial license were for hot operation, though, any subsequent failure of performance confirmation testing to re-confirm the basis for that license need not preclude a switch to cooler operation. The rule would also permit an initial phase of primarily cool operation even if the initial license allowed hot operation. The first stage of operation could involve emplacement of cooler waste in a low-temperature configuration, with only small quantities of hot waste emplaced for test purposes to confirm or demonstrate the basis for hot operation. In this way, little would have to be undone if the results of testing failed to support hot operation.

Because the results of confirmatory testing for either operating mode would determine the ability to operate hot after the initial testing period, the kinds of tests required for either the hotter or cooler mode would probably be much the same. Thus, deferring large-scale emplacement until after the thermal operating mode has been firmly established would reduce the impacts of a change from the mode initially approved.

Taken together, all of the above-cited selections from the rule make it difficult to argue that the Commission did not anticipate and expressly provide for empirically warranted changes in repository construction and operation to improve safety after issuance of the initial CA. Indeed, it would be difficult for the Commission to defend this rule as risk-informed and performance-based if it did not specifically provide for such changes as DOE acquires new information and insights building and operating this first-of-a-kind facility.

On a more historical note, it is also worth considering that at the time Part 60 was developed, NRC expected that the data available at the license application stage would be obtained from less than $\$ 100$ million of research in an underground test facility comprising about 1000 feet of drift. Today, the cross drift alone that connects the main excavations at Yucca Mountain is longer than that. Clearly, far more data are available today - representing the amount and quality of information that NRC, when Part 60 was written, would have expected to be obtained only after the CA, during the initial construction of the repository. DOE has since gone well beyond that modest effort. By 1993, it was planning a 6-year delay between the CA and the OL to construct a 
large surface facility and substantial underground emplacement area before starting disposal. Significantly, the previously cited DOE task force report on this plan argued that the Department should include in its application for a construction authorization a proposal to begin emplacement in a small test facility.

This context puts into a different and more accommodating light the Section 63.41(a) requirement that construction of the repository operations area be "substantially complete" before NRC can issue a license amendment to receive and possess radioactive materials. Under this paragraph, the Commission may issue such a license on finding that, among other things:

"Construction of the geologic repository operations area has been substantially completed in conformity with the application as amended, the provisions of the Atomic Energy Act, and the rules and regulations of the Commission. Construction may be deemed to be substantially complete for the purposes of this paragraph if the construction of:

(1) Surface and interconnecting structures, systems, and components; and

(2) Any underground storage space required for initial operation, are substantially complete."

There is a long-standing principle of jurisprudence under which, faced with apparently contradictory statutory mandates, courts should try to construe the law in a way that will permit the implementation of both requirements to the extent possible. If the provision for substantially completed construction here were construed to require DOE to construct all the facilities necessary to dispose of 70,000 metric tons equivalent before NRC could license the receipt and possession of any waste at Yucca Mountain, it would effectively render the rule's provisions for learning from implementation experience invalid. Compliance with the Commission's requirements for confirmatory testing and evaluation during construction, for example, would be operationally meaningless if the underground facility, having been substantially completed, could not be modified in any significant way to take advantage of lessons learned from waste emplacement

The same reasoning applies to the NRC requirement for completion of surface facilities as well. If DOE were required to build all the capacity needed for full-scale acceptance and emplacement before any wastes could be received, compliance with Part 63 requirements for performance confirmation, and for periodic evaluation of the continuing validity of facility license conditions, would be pointless for remedial purposes. DOE would be unable to use its experience with early waste handling and packaging to improve subsequent surface facility designs for safer pre-closure operation or better post-closure performance. For both surface and subsurface facilities, such a stringent interpretation of "substantially complete" construction would allow DOE and NRC limited recourse to meaningful engineering remedies if post-CA confirmatory studies brought unanticipated safety issues or potentially adverse post-closure performance trends to light. It would be difficult to show that this was what Congress intended or the Commission desires, particularly in light of NRC's stated commitment to RIPB principles. 
Fortunately, an alternative reading of this paragraph is not only possible, but persuasive. Section 63.41(a)(2) requires that the construction of underground storage space be substantially completed only for the space "required for initial operation." This implicitly envisions that the construction of underground storage space for emplacements after initial operation could be deferred under a phased approach to such emplacements.

Note also that under this paragraph, all the construction in question must be completed "in conformity with the application as amended ...." This signals a Commission expectation that DOE could propose and NRC could approve amendments to the original application for construction authorization as both agencies continue gathering and evaluating data from construction. It also suggests that, if DOE's application for the initial license amendment for waste receipt and possession provided for a small "initial operation" followed by expanded emplacement operations as results from the initial operation confirm its performance, "substantially complete" construction of only this small initial operation would enable NRC to approve receipt and possession "in conformity with the application." In any case, given its commitment to risk-informed, performance-based regulation, NRC will probably not want to impose conditions on any license amendment for waste receipt and possession in a way that would foreclose continuing data gathering and evaluation from construction as well as waste emplacement. The Commission would more likely want to regulate in a way that would permit both construction and emplacement to proceed "in conformity" with any license amendments the Commission may subsequently approve for either.

This reading of the Commission's requirement for "substantially complete" construction at least avoids an outcome that would render meaningful compliance with the other Commission requirements cited here all but impossible. Phased repository development is a prerequisite for optimizing ambient temperatures after initial operation, and a more literal interpretation of the requirement would preserve this option while still assuring that all the construction necessary to support initial repository operation would be "substantially complete." The narrower reading would also be most consistent with the Commission's risk-informed performance-based regulatory philosophy. Without the regulatory latitude for a phased completion of the construction authorized, it is difficult to see how future waste emplacement operations could be regulated to "provide flexibility to determine how to meet the established performance criteria in a way that will encourage and reward improved outcomes." 


\section{OFFICE OF CIVILIAN RADIOACTIVE WASTE MANAGEMENT SPECIAL INSTRUCTION SHEET lile list \\ Complete Only Applicable Items \\ 1. QA: N/A \\ Page: 1 of: 1 \\ 8 - 30.02}

This is a placeholder page for records that cannot be scanned.

\begin{tabular}{l|l}
$\begin{array}{l}\text { 2. Record Date } \\
08 / 09 / 2002\end{array}$ & $\begin{array}{l}\text { 3. Accession Number } \\
\text { ATT TO: MOL.20020830.0009 }\end{array}$ \\
\hline $\begin{array}{l}\text { 4. Author Name(s) } \\
\text { SCOTT GILLESPIE }\end{array}$ & $\begin{array}{l}\text { 5. Author Organization } \\
\text { N/A }\end{array}$ \\
\hline
\end{tabular}

6. Title/Description MODULAR CONSTRUCTIONSYSTEM EVALUATION

7. Document Number(s)

8. Version Designator

TDR-CRW-SE-000023

REV. 00

9. Document Type

DATA

11. Access Control Code

PUB

12. Traceability Designator

DC \# 31450

13. Comments

FHSEONTROLEED DOCUMENT EANBE LOCATED IN DOCUMENT CONTROLLAS VEGAS

CD ROM DISK
JR $9-3-02$

THIS DOCUMENT CONTAINS

AN ELECTRONIC ATTACHMENT 